\title{
نهو هجتمهع بيسئي إنساني:
}

\section{دراسة في فلسفة هوري بوكتشين}

\section{د. هببه البدوى (1)}

\section{الاقدمهة:}

يعد موري بوكتشين (Murray Bookchin) (1921-2006 ) من أبرز

المفكرين السياسيين, والاجتماعيين, والبيئين الأمريكيين في القرن العشرين, فهو أحد المفكرين المهمومين بقضـايا العصر وكل مانعاني منـه من أزمات ومشكلات علي كافة المستويات والأصسعدة ؛ ذلك أنـه حاول من خـلال كتاباتهأن يقدم لنـا تحليلً وافيًا لهذه المشكلات وتلك الأزمات, ولم تتوقف إسهاماته عند تشخيص المرض والبحث عن أسبابه الحقيقية, وإنما حاول أن يقدم لنا العلاج الذي يمكن من خلاله استئصال هذا الداء من جذوره, وهذا العلاج في رأيه هو المجتمع البيئي الإنساني.

وإذا تسالنا عن الذي يقصده موري بوكتشين بالمجتمع البيئي الإنساني نجد أنـه المجتمع الذي يتحقق فيـه التـوازن, والتكامـل, والتقاعل بـين البيئة الطبيعيـة والبيئة الإنسانية, فإن علة كل مشكلاتتا وأزماتتا يمكن إرجاعها في الأساس إلى غياب هذا التوازن الذي نتج عنـه تدهور شـامل على كافـة الأصـعدة السياسية, والاجتماعية, والاقتصادية, والبيئية, والإنسانية. والسبب الذي يقف وراء غياب هذا التوازن هو القضـاء على روح التعاون, والتعايش, والتآلف بين البشر من خلال الرغبة في الهيمنة التي يسعى من خلالها بعض البشر إلى فرض هيمنتهم علي 
بعضهم الآخر , وقد أدى ذلك إلى أن أصبحت لغة العنف, والصراع, والتتافر تحل

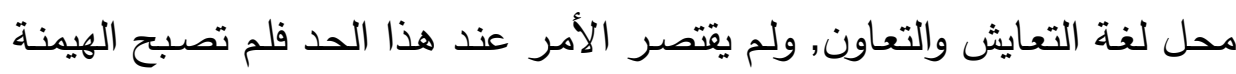

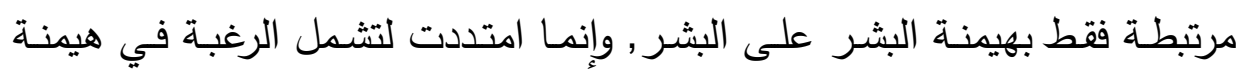
البشر على البيئية الطبيعية وإثبات تفوقهم وسيادتهم عليها, وبالتالي إلغاء التوازن, والتفاعل, والتكامل الذي استمر على مدار تاريخ طويل بين البيئة الطبيعية والبيئة الإنسانية وقد أدى ذلك إلى تشويه البيئتين الطبيعية والإنسانية وتخريبها. لذلك فإن الحل الذي يقدمهـ موري بوكتثين هو المجتمع البيئي الإنساني الذي نستعيد فيه التوازن, والتقاعل, والتكامل بين البيئتين الطبيعية والإنسـانية,

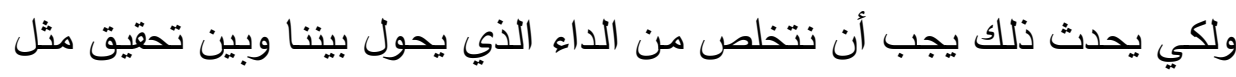

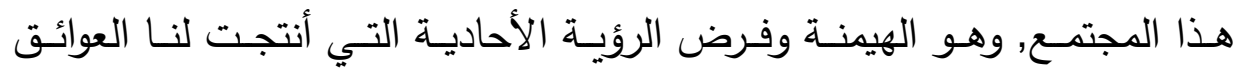

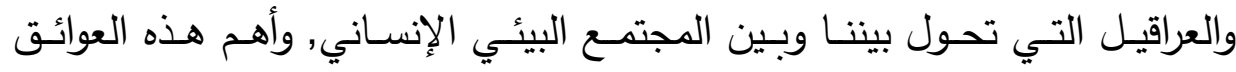

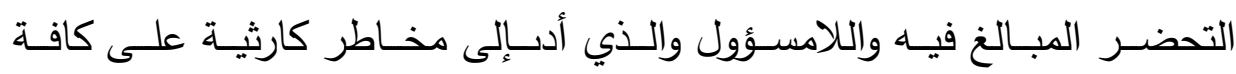

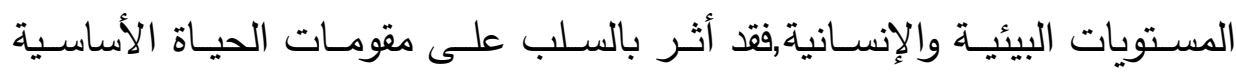

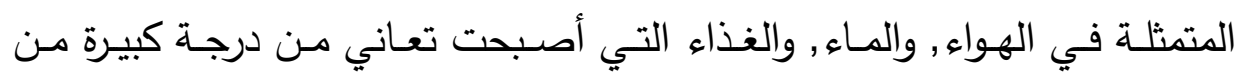

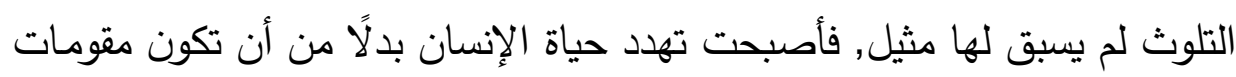
حياته الأساسية. ولم يقتصر الأمر عند هذا الحد, وإنما اتسعت دائرة التدهور

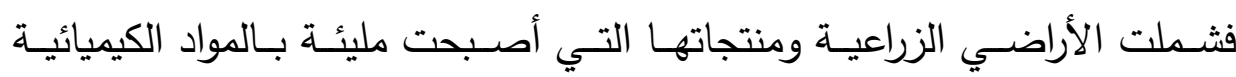

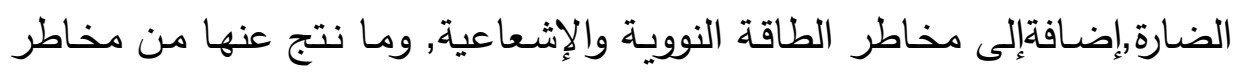

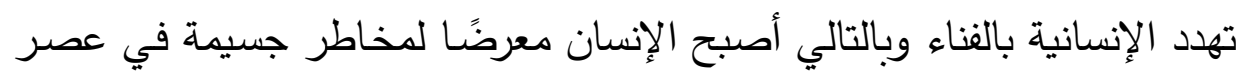
التحضر اللامسؤول, فقد أدى تلويث البيئة المحيطة بالإنسان إلى تدهور صحته

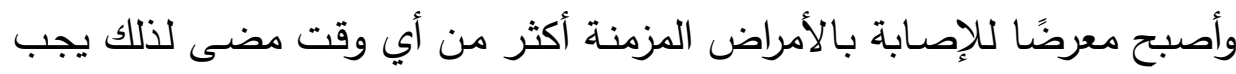
أن يتم التخلص من هذا العائق المتمثل في التحضر المبالغ فيه من خلال التركيز 
على البيئة الاجتماعية التي سيكون بمقدورها إعادة التوازن بين البيئتين الطبيعية والإنسانية.

وقد نتج عن هذا الداء المتمثل في فرض الهيمنـة والرؤيسة الأحادية تدهور سياسي تمثل في الدولة المركزيـة التي أصبحت صـاحبة السلطة الوحيدة, وبالتالي تم تغييب المواطن ولم يعد لله دور سياسي حقيقي في صنع مجتمعه وواقعه. وحل الذي يقدمـه موري بوكتشين هو ضـرورة وجود مجتمع مدني ليحل محل الدولـة المركزيـة, إنـه المجتمـع الذي سيكون فيـه للمواطن دور حقيقي في صنـع سياسـة مجتمعه من خلال ديمقراطية حقيقية يتمتع فيها المواطن بكل حقوقه وحرياته التي ستمكنه من خلق هذا المجتمع, ويستشهد موري بوكتشين بالمدنية اليونانية بوصفها نموذجًا حيَّا لهذا المجتمع المدني يمكن أن نستقيد منه في وقتنا الراهن. ثم يقدم لنا موري بوكتشين برنامجًا شاملًا يضع من خلاله الملامح الأساسية التي يمكـن أن يسترشـد بهـا هـا المجتمـع البيئي الإنسـاني التحـرري سياسـيًا, واجتماعيًا, واقتصاديًا, وبيئياً, وإنسانيًا موضحًا أن هذه الأسس مجتمعة تعتمد في الأسـاس على استعادة الارتباط, والتوازن, والتفاعل, والتكامل بين البثر بعضها بعضًا من جهة وبين البشر وبيئتهم الطبيعية من جهةأخرى؛ لأن البيئة الإنسانية هي جزء لا يتجزأ مـن البيئة الطبيعيـة التي تمدنا بمقومـات الحيـاة, لذلك يجب الحفاظ عليها إذا أردنا الحفاظ على وجودنا وبقائنا على قيد الحياة. إن بحث موري بوكتشين عن مجتمع بيئي إنسـاني يتحقق فيه التوازن بين البيئتين الطبيعيـة والإنسـانية كـان لـه جذور تاريخيـة وفلسـفية عميقـة فقد تـأثر بالمجتمعات البدائية, ومن بينها المجتمعات الهندية واستشهد بها كأمثلة حية لهذا التوازن, وتأثر بالمدنية اليونانية, إضافةإلى ما حقتته المدن الإيطالية في العصور الوسطى, وكذلك تأثر بالإنجازات المتحققة في أعقاب الثورتين الفرنسية والأمريكية, 
إلى جانب الثورة الإسبانية في ثلاثينيات القرن العشرين والجهود التي قامت بها

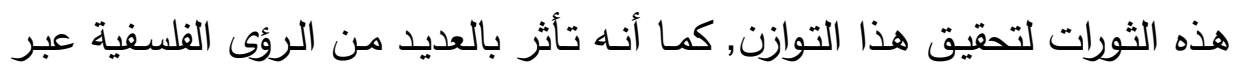
تاريخ الفكر الفلسفي ؛ فقد استفاد من الفلسفة الطاوية التي أعطت اهتمامًا كبيرًا

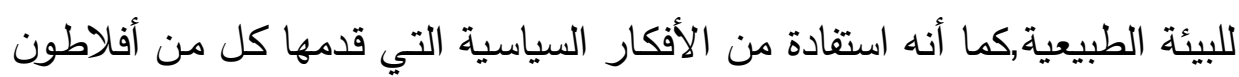

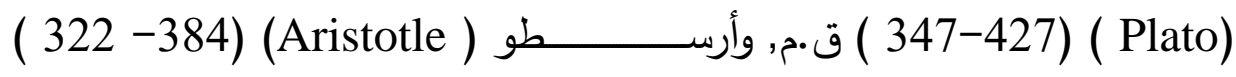
ق.م,حول أهمية الددينة ودور المواطن, وتأثربالآراء الرواقية التي كانت تحث علي التي

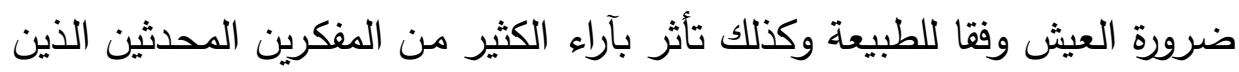
أعطوا أهمية كبيرة لسلطة الشعب وأكدوا على ضرورة أن يكون للمواطن دور فعال

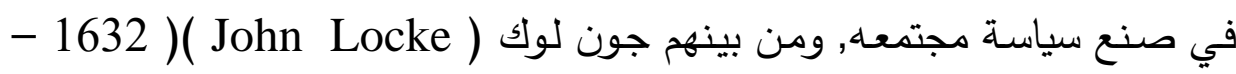
1704), و جـان جـاك روسو (Jean Jacques Rousseau)

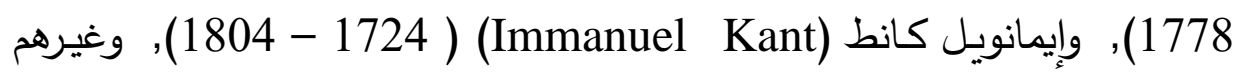
كما أنه تأثر بأغلبية الدفكرين المعاصرين الذين نظروا إلى الهيمنة على أنها علة

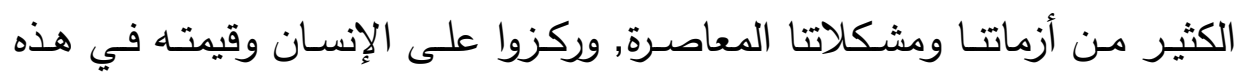

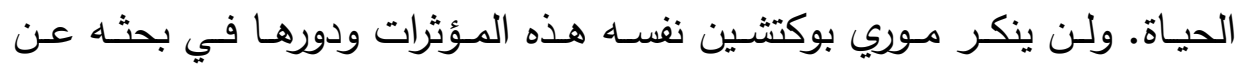

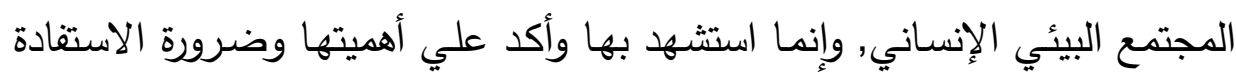
منها, إذا أردنا أن يصبح هذا المجتمع حقيقة حية ملموسة. ترجع أهيـة هذا البحث إلى أهمية الهدف الذي يسعى موريبوكتثين إلى تهى

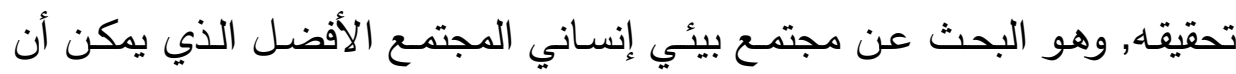

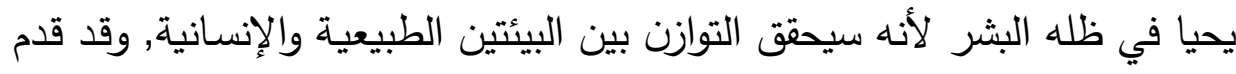

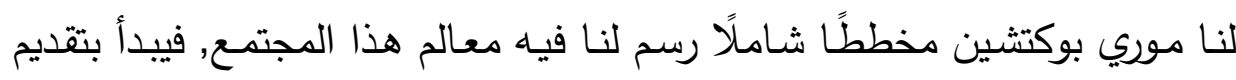

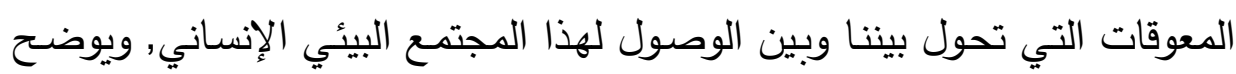
لنا العلل الحقيقية التي أدت إلى وجود هذه المعوقات, ثم يقدم لنا البرنامج الثامل

\section{( 4 )}


الذي يمكن أن نسترشد به للتخلص من هذه المعوقات لما به من ركائز سياسية, واجتماعية, واقتصـادية, وبيئية, وإنسانية يمكن أن تتير لنا الطريق ليصبح هذا

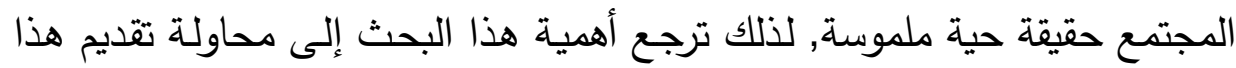
الجها الذي قام به موري بوكتثين في سعيه نحو المجمع البيئي الإنساني؛ لنثبت

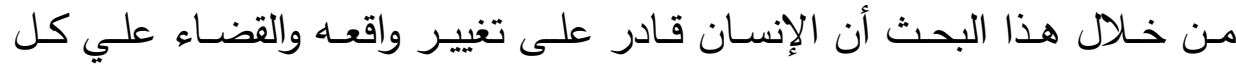

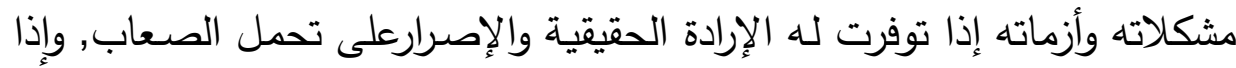
توفرت لـه الأرض الخصبة والبيئة الملائهـة التي تعينه على تحقيق هذا الهدف الذي لن يتحقق إلا من خلال كل الجهود الواعية التي يكون قوامها الحوار البناء

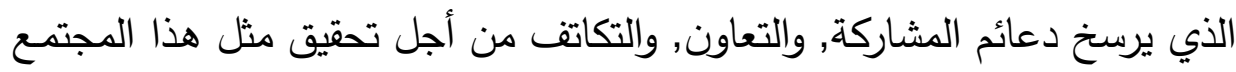
البيئي الإنساني الذي يمكن أن يتحول من ما ينبغي أن يكون إلى ما هو كائن إذا

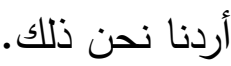

يحاول هذا البحث الإجابة عن بعض التساؤلات أهمها ما الذي يقصده موري بوكتثين بالمجتمع البيئي الإنساني؟ و ما المخاطر التي تحول بيننا وبين تحقيق

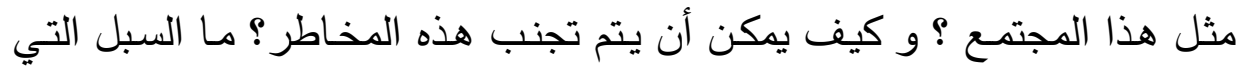

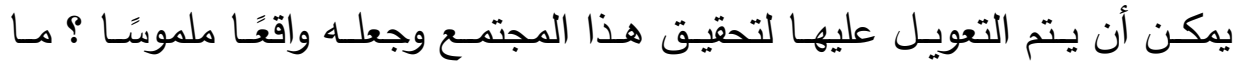
البرنـامج الثـامل الذي قدمـه موري بوكتثـين لتحقيق مثل هذا المجتهع ؟ ومـا

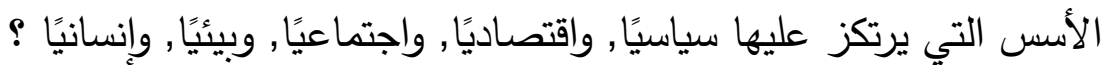

\section{1- التهضر الزائف وعلاقته بالتدهير البيئي والإنساني}

إن ما يقصده موري بوكتثين بالمجتمع البيئي الإنساني هو المجتمع الذي

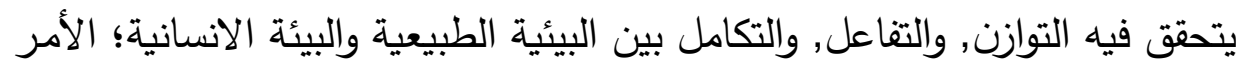

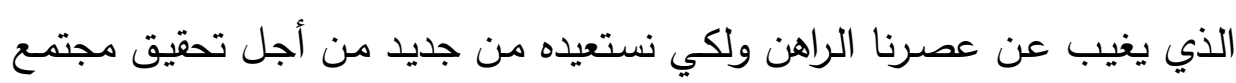


بيئي إنساني يجب أن نكون على وعي بالأسباب الحقيقية التي أدت إلى غيابه,

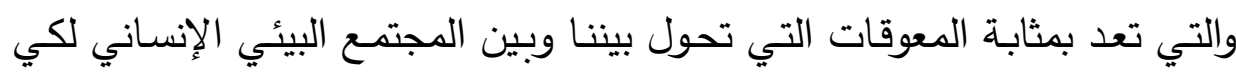

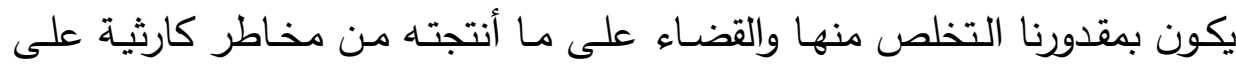

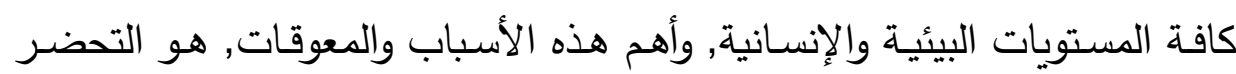
المبالغ فيه واللامسؤول.

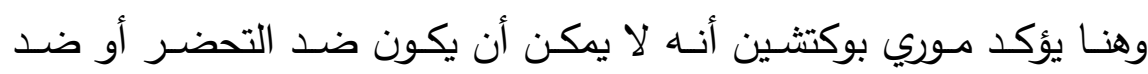

التطورات العلمية والتكنولوجية التي كان لها آثار مفيدة بلا شك على بلى حياة الإنسان ورفاهيته, فإننا نعيش في عصر يتمتع فيه الإبداع البشري, والتكنولوجيا, والخيال

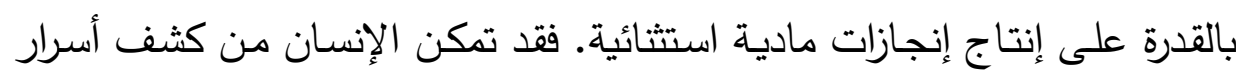

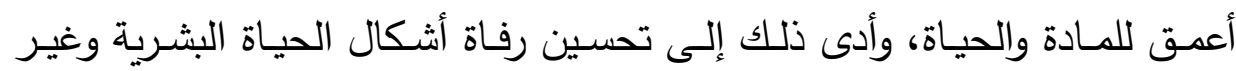

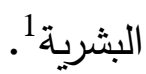

وهنـا يوضـح أن اعتراضــهـ يكـون منصـبًا فقط على التحضـر اللامسؤول

والمبالغ فيه, والذي تكون له آثار مدمرة على البيئة الطبيعية والإنسانية على حد

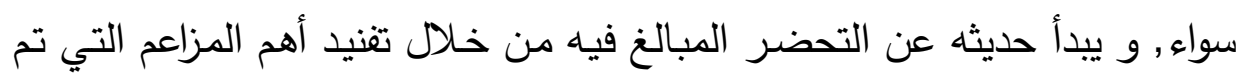

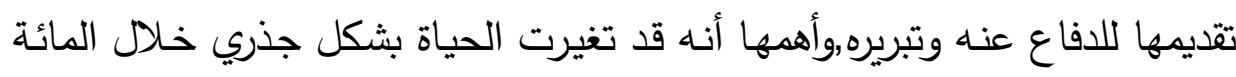

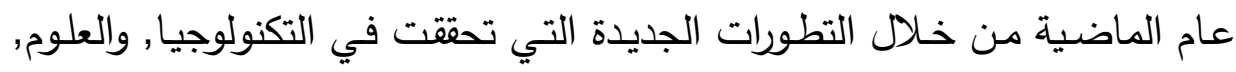
والطب. فإن البشر اليوم قد سيطروا سيطرة شبه كاملة على القوى الطبيعية التي

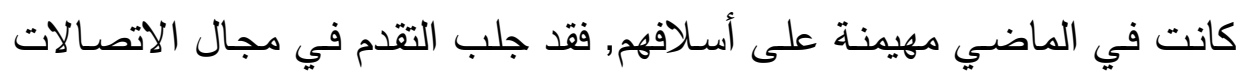
المعرفة والسلامة إلى المجتمعات الأكثر عزلة, وأصبحت الآلات تؤدي الأعمال

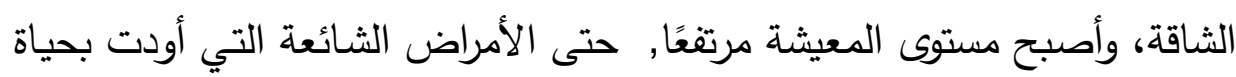

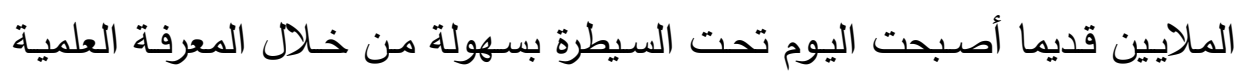
بـالمرض, والعقـاقير الفعالــة, وأجهـزة التثـخـيص الجديـدة, والتقنيـات الجراحيـة

\section{( 6 )}


المتقدمة, ومن ثم أصبح لدى الأفراد مزيد من أوقات الفراغ يستمتعون بها, إلى

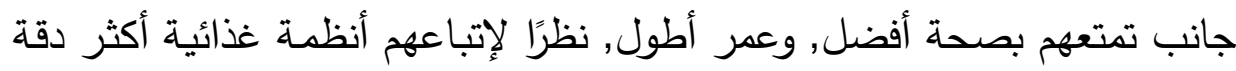

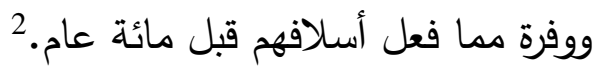
وهنا يؤكد موري بوكتثين أن هذا الوضع قد يكون صحيحًا في ظاهره، لكن التمعن فيه يثبت عدم صحة كثير من مزاعمـه؛ فقد أحدثت الثورات الصناعية

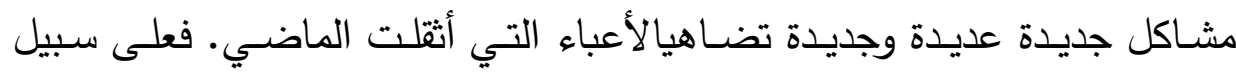

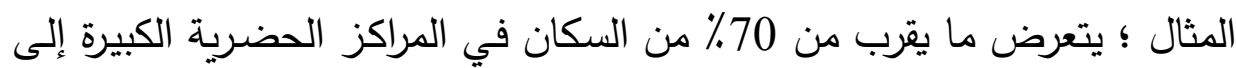

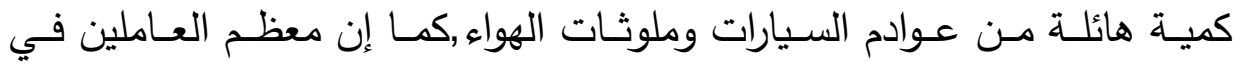

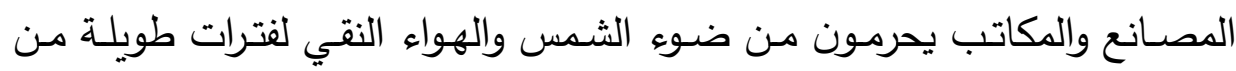
اليوم,وإلى جانب أن استخدام الآلات في العمل قد يجعل العمل أقل مشقةرةلكنه

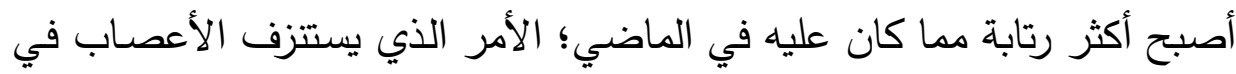

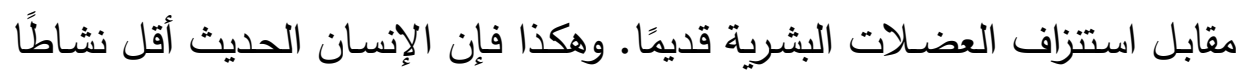

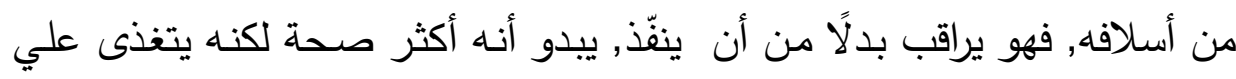

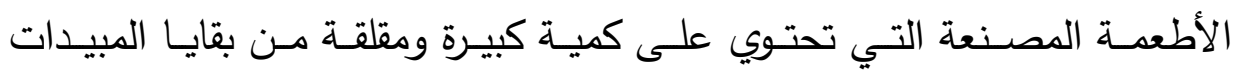

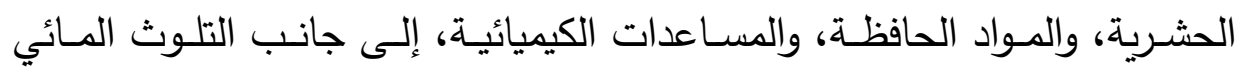

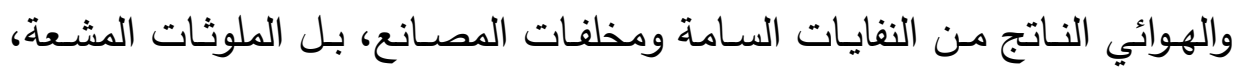
والمنتجات الثانوية لاستخدامات الطاقة النووية واختبارات الأسلحة النووية؛ وفي ضـوء ذلك يرى موري بوكتثـين أنها يمكن تلخيص مشكلات بيئتنا

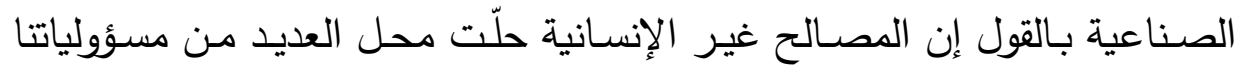
تجاه الرفاهية البيولوجية البشرية, فإلى حد كبير يتم وضـع احتياجات المنشآت

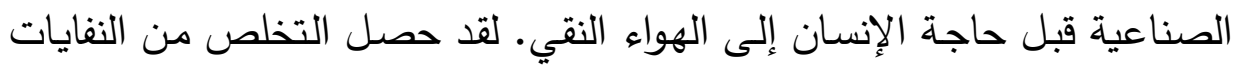
الصناعية على أولوية أهم من حاجة المجتمع للمياه النظيفة. ومن هنا فإن الآثار

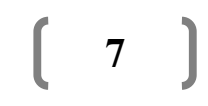


المدمرة للتحضر المبالغ فيه تعود في الأساس إلى رغبة الإنسان في فرض هيمنته

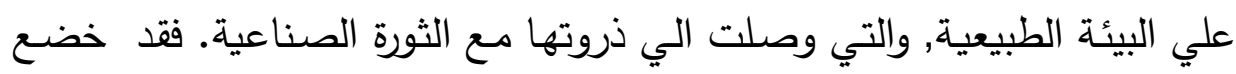
مفهوم السيطرة على البيئة الطبيعة لتغيير جذري, حيث تم استبدال كلمة "طبيعة" بعبارة "الموارد الطبيعية", وعدّ قادة الصناعة الجديدة الأرض, والغابات, والحياة

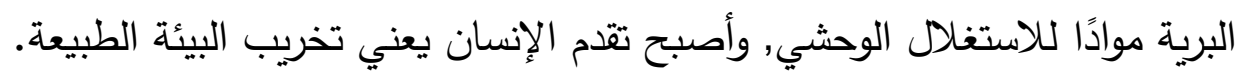

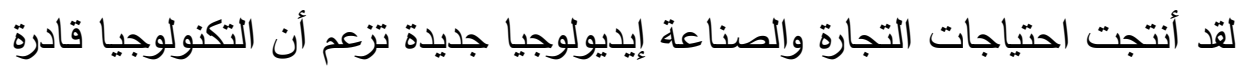
على منح الإنسان القدرة الكاملة على إخضاع البيئة الطبيعية لسيطرته الكاملة؛ والنتيجة المترتبة علي ذلك هي أن المجتمع يواجه الآن انهيارًا ليس فقط

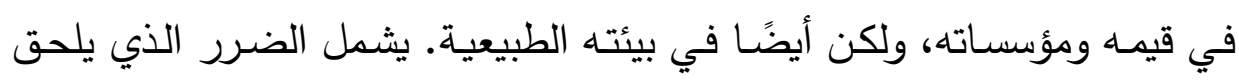

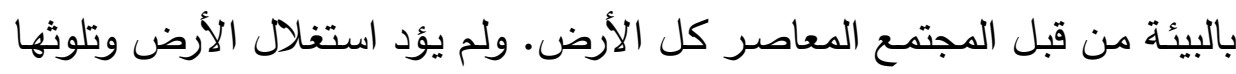

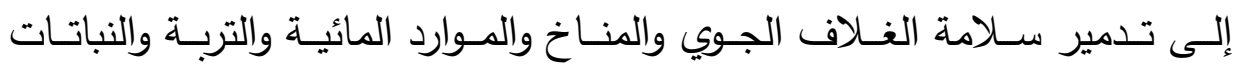
والحيوانات في مناطق معينة فحسب، بـل أيضـا إلى إحداث خلل في الدورات الطبيعية الأساسية التي تعتمد عليها جميع الكائنات الحية 5. إن "الحضارة" كما نعرفها اليوم والتي تدعي أنها تهيمن على البيئة الطبيعية

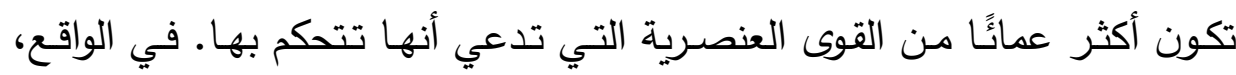

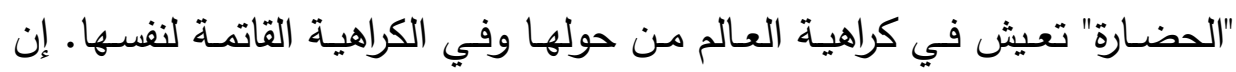

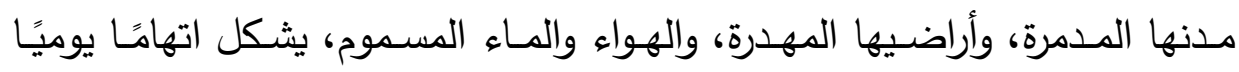
لأخلاقها البغيضة. ولو كان تاريخ هذا الكوكب، بما في ذلك تاريخه البشري، مليئاً

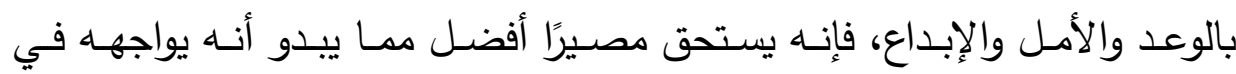
السنوات القادمة 6.

وهنا يؤكد موري بوكتثين أن العالم اليوم لا يواجه أزمة واحدة ، بل سلسلة

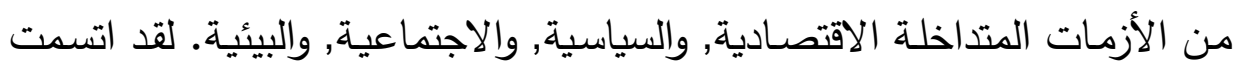


الألفية الجديدة بفجوة متتامية بين الأغنياء والفقراء وصلت إلى مستويات غير

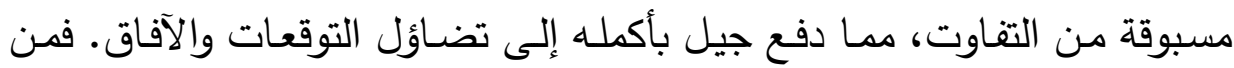

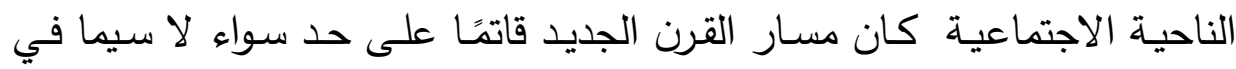

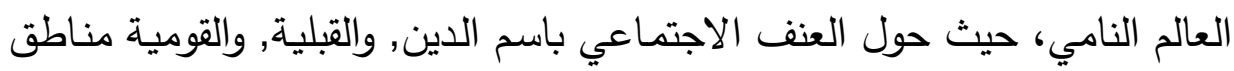
بأكملها إلى مناطق صدام لا يمكن تحمله. وفي الوقت نفسه تفاقمت الأزمة البيئية

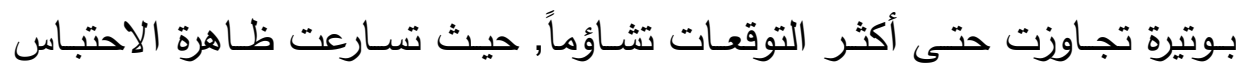
الحراري, وارتفاع منسوب مياه البحار , وتلوث الهواء, والتربة, والمحيطات, وتدمير

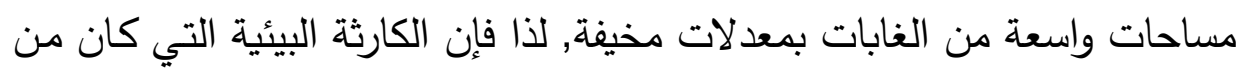

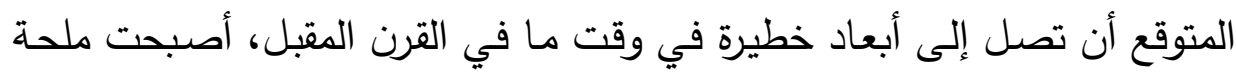

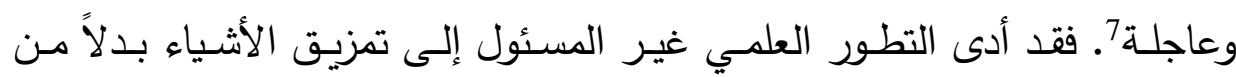
دمجها، وبالتالي أدى إلى الهدم بدلاً من البناء 8. لقد أنتجت البشرية الاختلالات ليس فقط في الطبيعة، ولكن بشكل أكثر

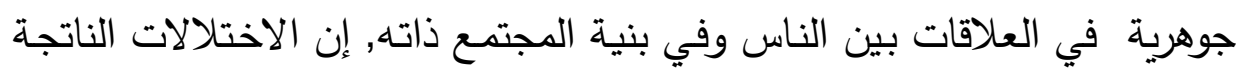

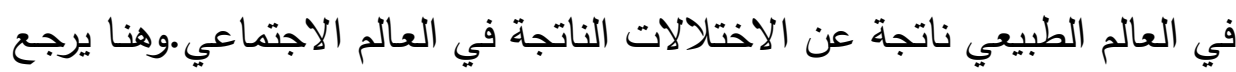
موري بوكتثين كل هذه الإخفاقات إلى الإفساد الذي تعرضت له البيئة الطبيعية

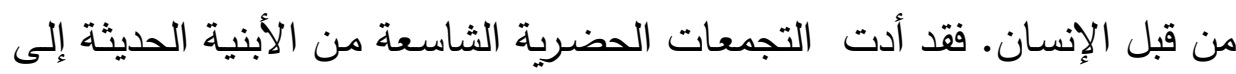
تجاوز النظم البيئية المعقدة وتقويضها, والتي تنظم ببراعة من خلال استبدال بيئة عضوية معقدة للغاية ببيئة غير طبيعية مبسطة, وقد أدى ذلك إلى تنكيك الهرم الإحيائي الذي دعم البشرية لآلاف السنين. وإذا استمر هذا الانقلاب الكبير في في لئه

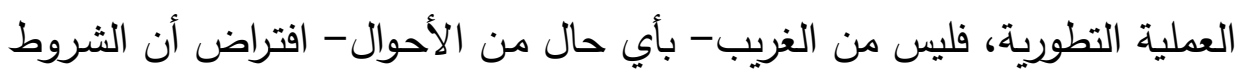

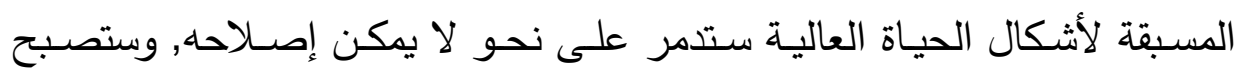
الأرض غير قادرة على دعم البشرية'. 
وهنا يؤكد موري بوكتثين أن الخطأ الجسيم الذي وقع فيه التحضر المبالغ

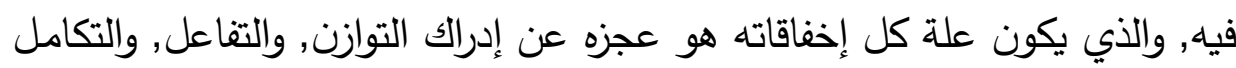

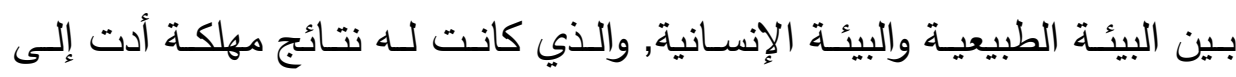

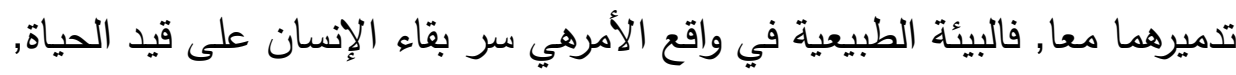

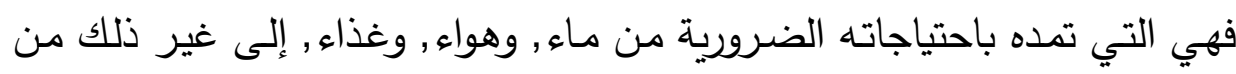

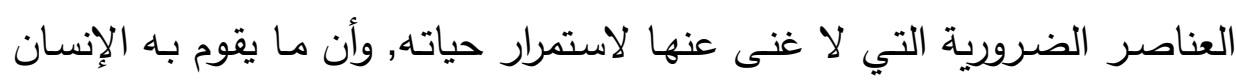

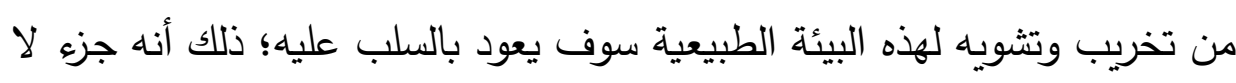

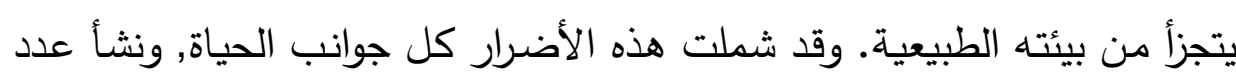

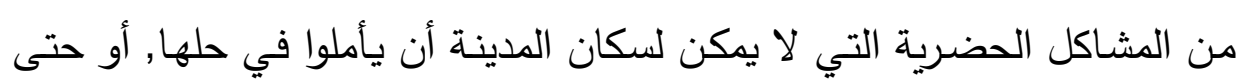

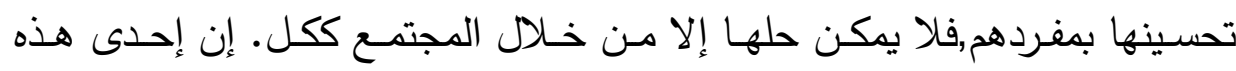
المشاكل، وهي تلوث الهواء قد أصبحت منتشرة على نطاق واسع وتثكل خطرًا

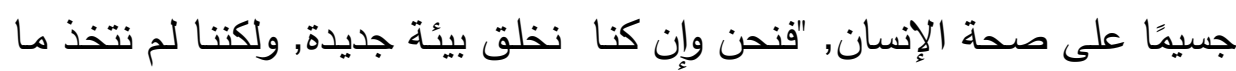

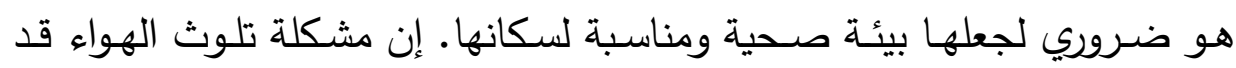

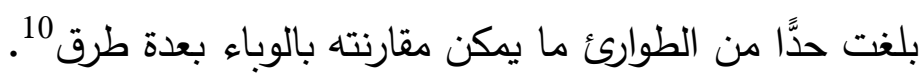

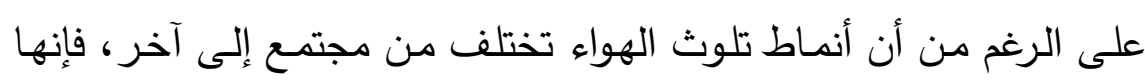

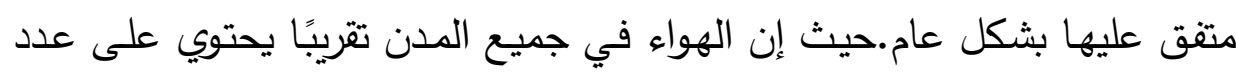

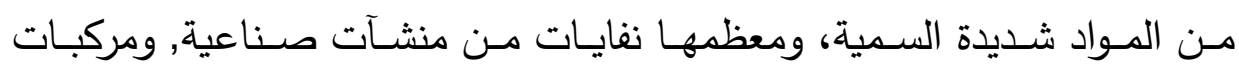

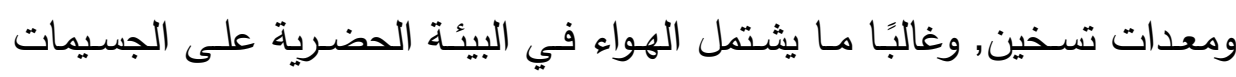
الصلبة التي تحتوي على مواد شديدة السمية مثل الرصاص, والبيريليوم, والزرنيخ.

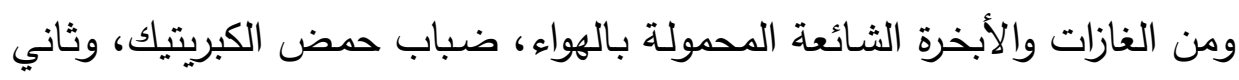

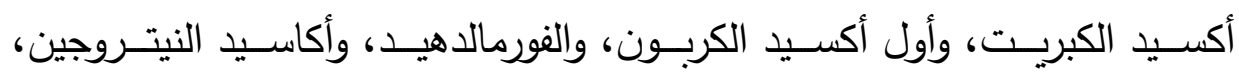

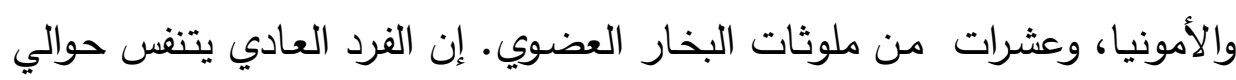


16000 لتر من الهواء يوميًا. إذا كان يعيش في بيئة حضرية، فإن رئته تتلقى ما

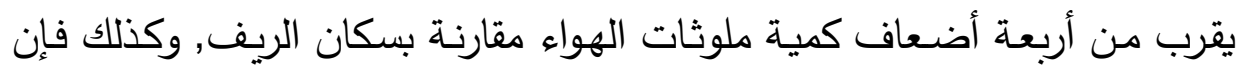

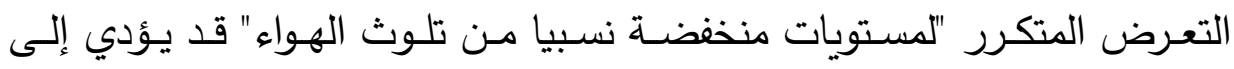

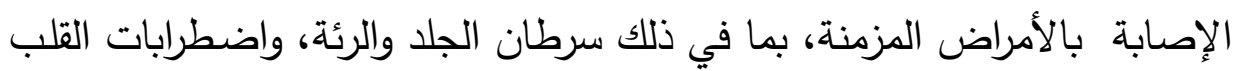

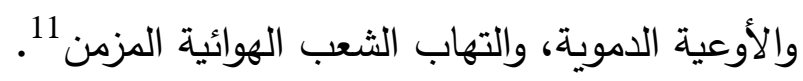
كذلك فإن حرق الوقود الحفري (الفحم والنفط) يضيف 600 مليون طن من ثاني أكسيد الكربون إلى الهواء سنويًا، أي حوالي 3\% من إجمالي كتلة الغلاف الجوي, هذا إلى جانب كمية لا تحصى من المواد السامة. ومنذ الثورة الصناعية

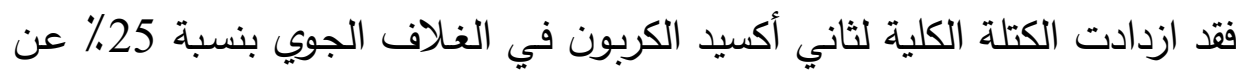
المستويات السابقة والمستقرة. ويمكن أن يقال على أساس نظري سليم جدًا أن هذه أنهات

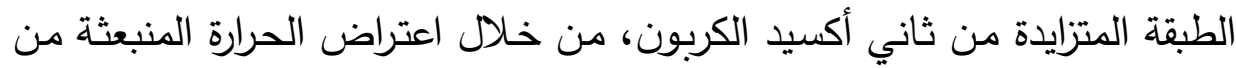

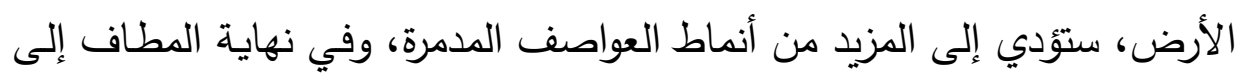

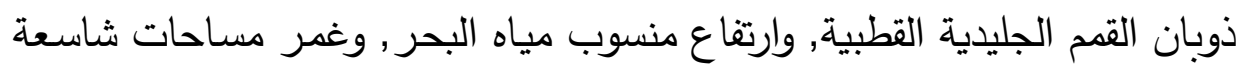

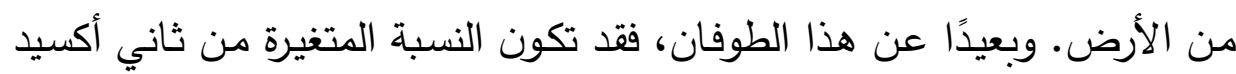
الكربون إلى غازات الغلاف الجوي الأخرى بمثابة تحذير حول التأثير الذي يحدثه الناس في تدمير الطبيعة 12. هناك مشكلة أخرى لا يمكن حلها دون تعاون المجتمع بأكمله, وهي تلوث

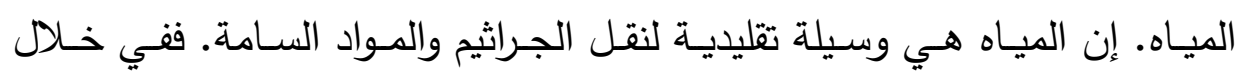

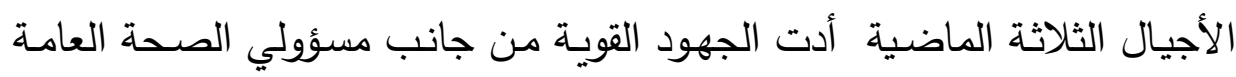
إلى الحد بشكل كبير من المخاطر التي تسبها العوامل المعدية التي تنقلها المياه،

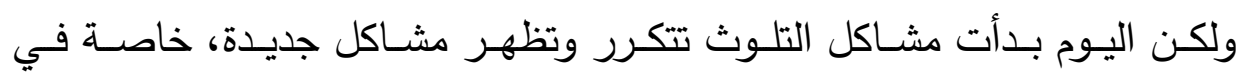
المجتمعـات التي تعتمد بشكل كبير على الأنهار ـ فإن كميـة هائلــة مـن ميــاه 
الصرف الصحي غير المعالجة, أو المعالجة بشكل غير ملائم يتم تصريفها في ميـاه النهـر , التـي عـادة مـا يـتم تتاولهـا مـرة أخـرى للاسـتهلاك العـام مـن قبـل المجتمعات المحلية في اتجاه مجرى النهر • إضـافة إلى أن مياه الصرف الصحي في المناطق الحضرية هي نفايات من المصانع الكيميائية والنفايات المعدنية. على الرغم من أن مخلفات الصرف الصحي والنفايات الصناعية أنتجت أزمات محلية للصحة العامة في الماضي، فإن توسع المدن والمناطق الحضرية في فترة ما بعد الحرب يحول تلوث المياه إلى مشكلة وطنية خطيرة، يمكن مقارنتها في العديد من النواحي بالمشكلة الناشئة عن تلوث الهواء في المدن قد تحتوي مياه الثرب اليوم على مجموعـة واسـعة مـن المبيضـات, والمنظفـات الجديـدة, والبتروكيميائيـات, والنفايات المعدنية, والمبيدات الحشرية, والأصباغ والمركبات المشعة, وقليل من أي من هذه الملوثات يتم إزالته بالطرق العادية لتنقية المياهُ13. ومن المخاطر الكارثية التي أنتجها أيضًا التحضر اللامسؤول والمبالغ فيه تلوث الغذاء. والقضاء علي الجزء الأكبر من قيمته الحقيقية. فمع صعود مجتمع متحضر يصبح إنتاج الغذاء عملية صناعية مقدة. وعلى النقيض من الأوقات السابقة عندما تم إجراء عدد قليل جدًا من التغيرات في مظهر الغذاء أو مكوناته، فـإن معظم المـواد الغذائيـة المستهلكة تتم معالجتهـا بشكل كبيـر , وقد اسـتولت المصـانع التجاريـة على 85 في المائـة من هذه المواد الغذائية التي كانت قبل جيـل مضـى جـزةًا مـن المزرعـة والحيـاة المنزليـة. وغالبـاً مـا يـتم إضـافة المـواد الحافظة للأطعمة للسماح بتخزين أطول، ويتم وضع المواد المنكهة الاصطناعية في العديد من الأطعمة المصنعة لتحسين مذاقها, وحتى في الحالات التي يكون فيها المظهر , والذوق, والنعومـة مؤشرًا حقيقيًا على الجودة الغذائية الفائقة، فإن 
المعالج كثيرا ما يستخدم مجموعة كبيرة ومتنوعة من المواد الكيميائية لجعل منتج أقل شأناً، أو قديم، أو مكرر بشكل مفرط يبدو عالي الجودة 14. وإلى جانب الخداع الذي يمارسونه على المستهلك، فإن العديد من المواد

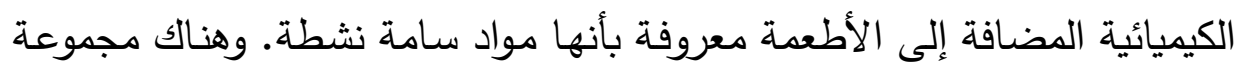

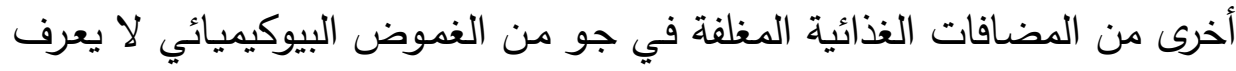

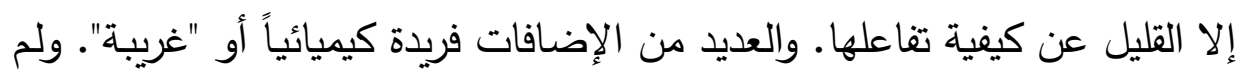
يتم بعد تحديد آثارها طويلة المدى على جسم الإنسان تستخدم المواد الكيميائية في

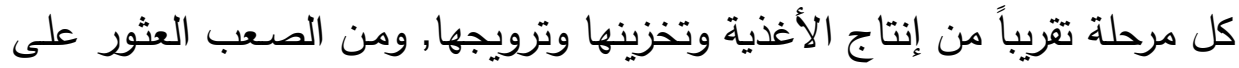

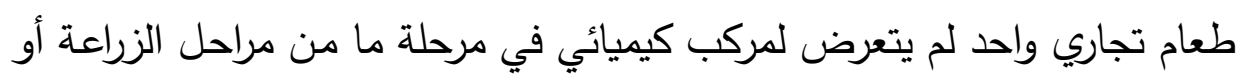

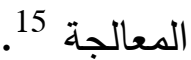

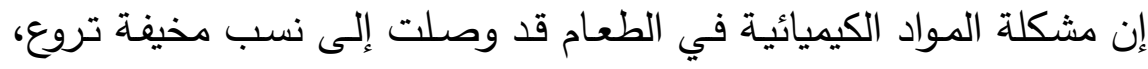
حيث زادت الإصابة بكثير من الأمراض مثل السرطان الناتج عن المواد الكيميائية

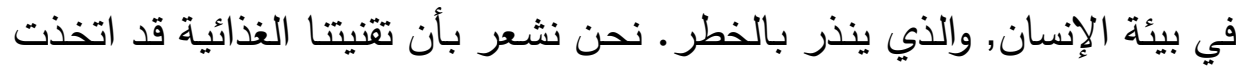

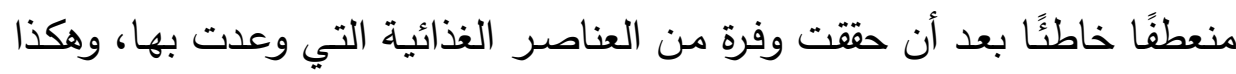

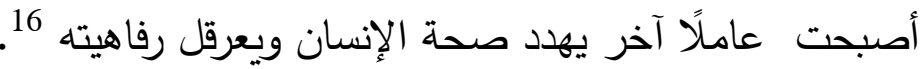

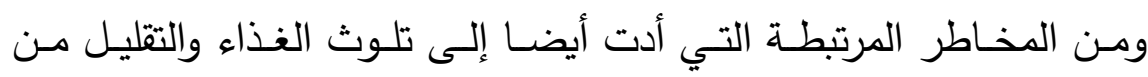

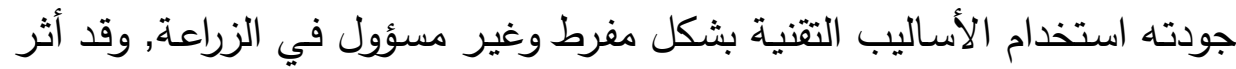

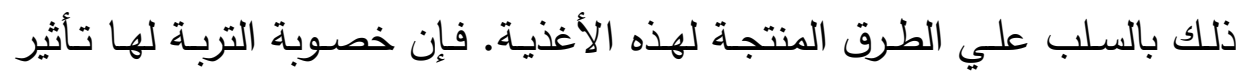
عميق على جودة الطعام, وإن تدهور خصوبة التربة وبنيتها يؤدي إلى نقص في هذه الجودة؛ هذه المحاصيل قد تلبي متطلبات نقص الغذاء ولكن ليس بالضرورة متطلبات الإنسان من غذاء جيد وصحي ما إذا كانت التربة خصبة بشكل صحيح

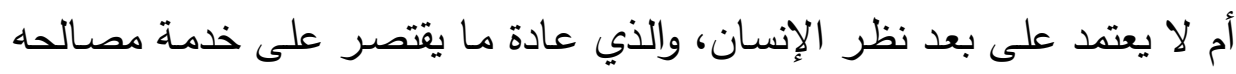


الاقتصادية قصيرة المدى. كذلك، فإن زراعة نوع نباتي واحد في جزء معين من

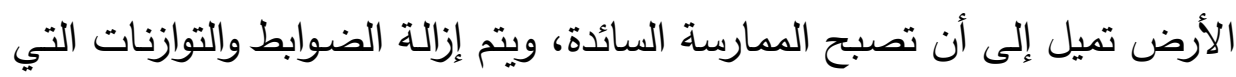

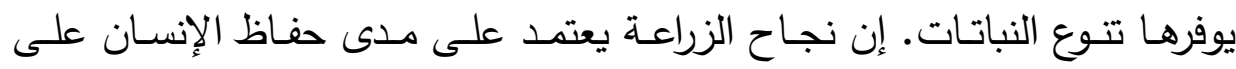

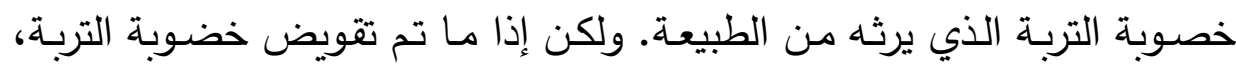

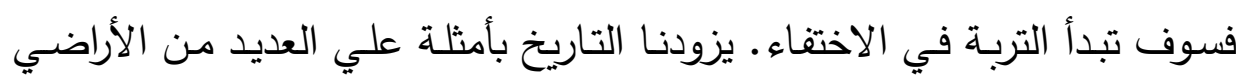

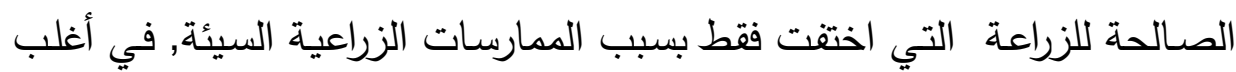

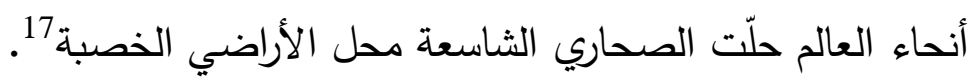
وتتجلى المشـاكل التي يخلقها نزاعنـا مـع الطبيعـة بشكل كبير في حربنـا

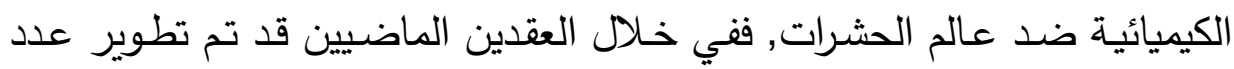

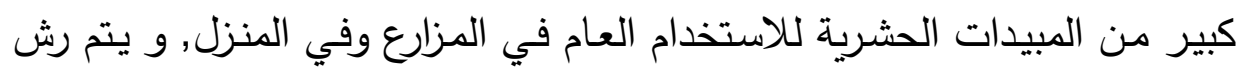

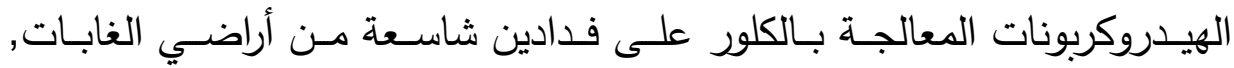
وأراضي المراعي, وأراضي المحاصيل، وحتى الأراضي شبه الصحراوية. وهكذا

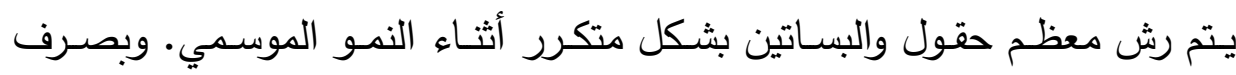
النظر عن المخاطر التي تسبيها المبيدات الحشرية للصحة العامة، فإن الاستخدام الككثف للمبيدات الحشرية الجديدة يضعف قدرة الحياة البرية والحشرات المفيدة في

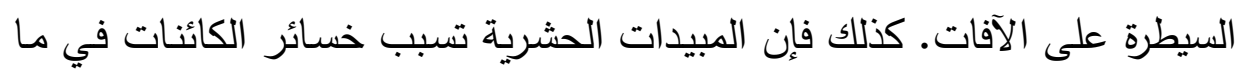

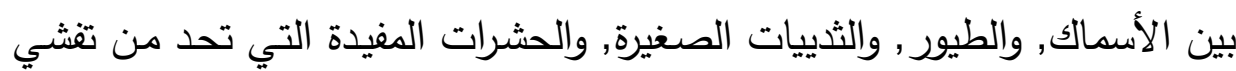

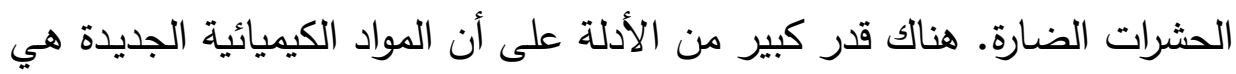

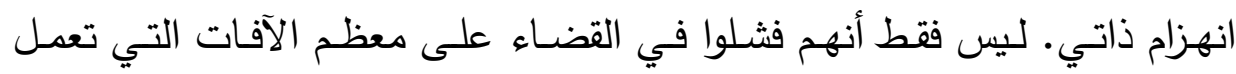

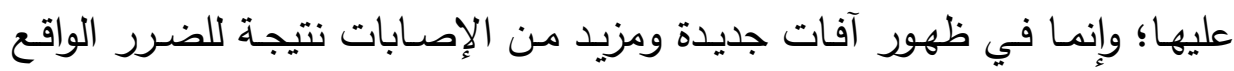
على الحيوانات المفترسة للأنواع التي كانت تحت السيطرة 18. 
ولتفاقم الضرر تنقل المياه السطحية والجوفية المبيدات الحشرية إلى الجداول

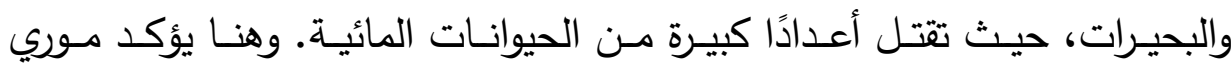
بوكتثين أنها إذا استمر انهيار التربة في الكون دون هوادة، وإذا استمرت حالة

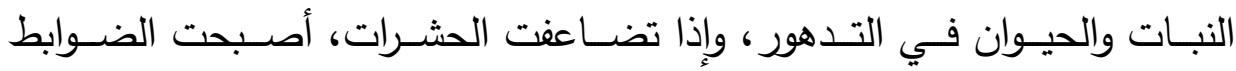
الكيميائية مميتة بشكل متزايد، فإن العديد من الثروط المسبقة للحياة المتقدمة ستكون غير قابلة للإصلاح وستثبت الأرض أنها غير قادرة على دعم نوع بشري الثرطي صالح وصحي 19. وتباعًا لما سبق وجب علينا أن نترك مجالاً أكبر للعفوية الطبيعية، وللقوى البيولوجية المتتوعة, ومن ثم فإن الزراعة الغذائية التي تمارس بمفهوم بيئي حقيقي

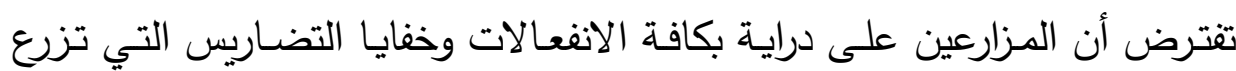
فيها المحاصيل, يجب أن تكون لديهم معرفة دقيقة بعلم طبيعة الأرض والتربـة

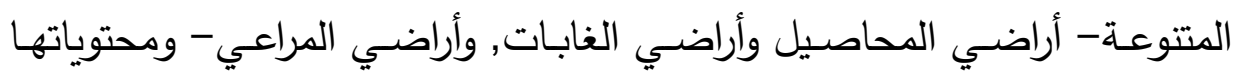

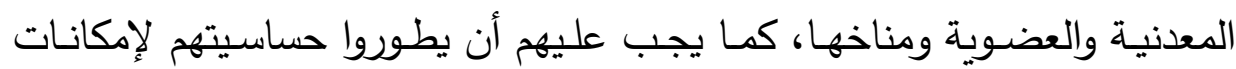

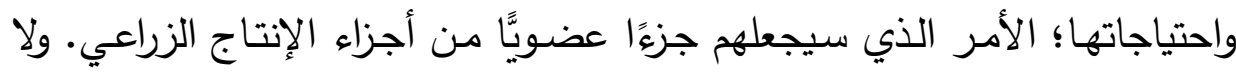

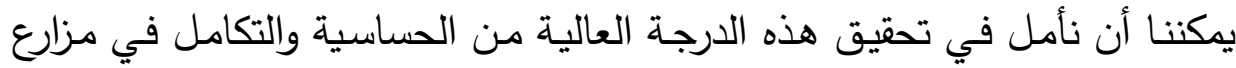
الطعام دون التقليل من الزراعة إلى ما يكفي حاجة الإنسان لتلبية منطلبات النهج

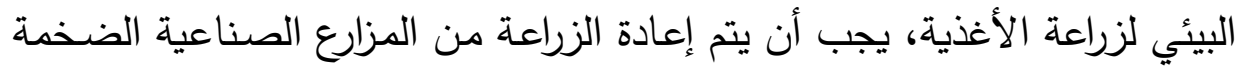
إلى الوحدات متوسطة الحجم 20. وهنا يشير موري بوكتثين إلى المخاطر الجسيمة التي أحدثها التحضر اللامسؤول على صحة الإنسان بشكل عام, فقد نشأ عن التدهور الذي أحدثه

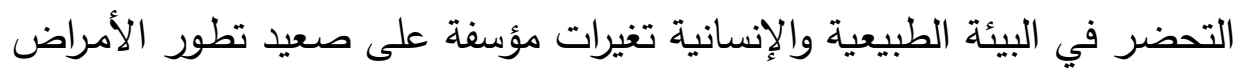
وتفاقمها. فيما مضى كانت الأمراض المعدية، مثل الالتهاب الرئوي، والأنفونزا، 
والسل، هي الأسباب الرئيسة للوفاة, في حين احتل الموت من أمراض القلب

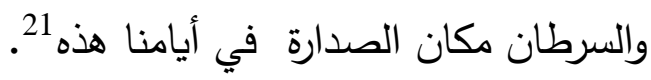

ولمعرفـة الأسباب التي أدت إلى انتشــار الأمسراض وتفاقهها, سيكون مـن

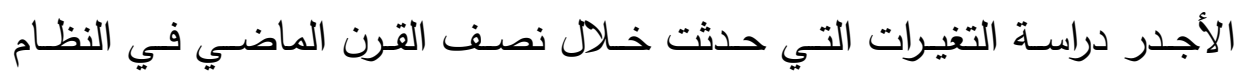

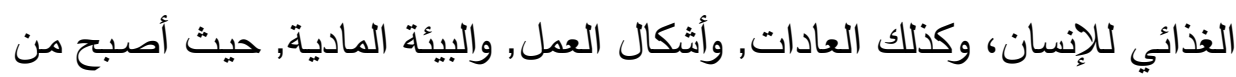

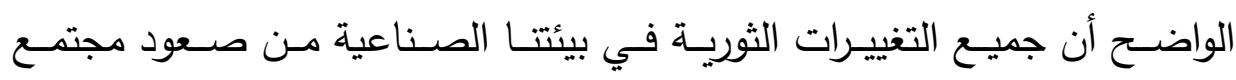
حضري إلى استخدام الطاقة النووية لها آثار بيولوجية عميقة، وأن هذه التغييرات التئية أضافت بعدًا بيئًا إلى كل مجال من مجالات الصحة العامة تقريبًا 22. وهنا يري موري بوكتثين أن اعتلال الصحة أمر قائم بشكل طبيعي قبل أن يتضح بشكل طبيّ، ويترتب على ذلك أنه ينبغي ممارسة أقصى قدر من العناية العنية

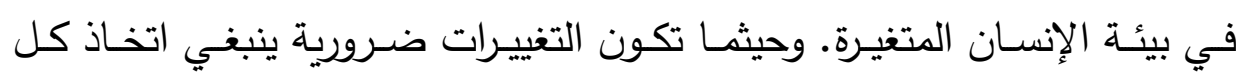
الاحتياطات لتقليل أي آثار ضارة على جسم الإنسان. فليس من الصواب إدخال

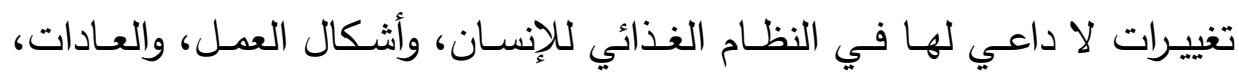

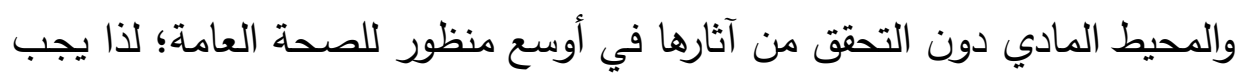

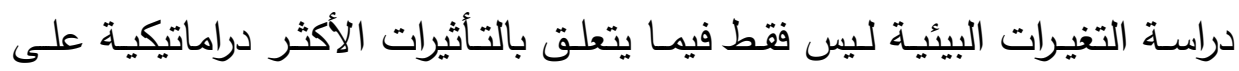

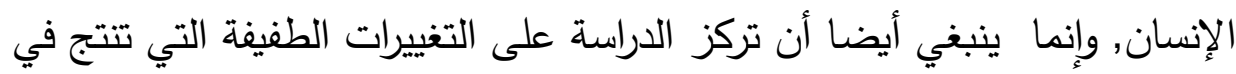

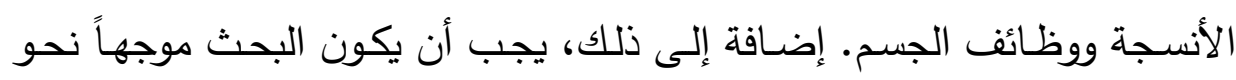

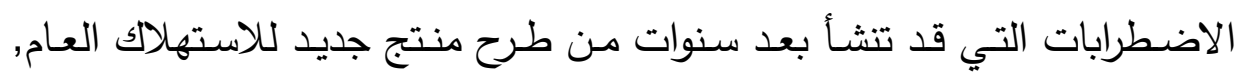

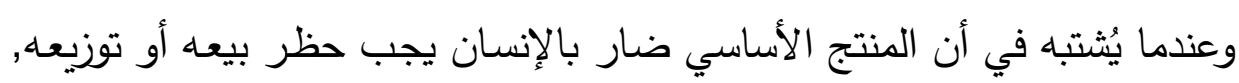
ويجب أن يشمل مفهوم المرض المستحث بيئياً جميع المستويات البنيويـة للكائن

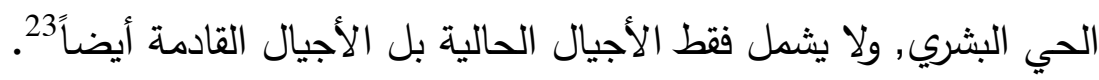


ولتحقيق "رؤية كاملة" يجب أن يكون هناك تكامل في طرق البحث والتحكم,

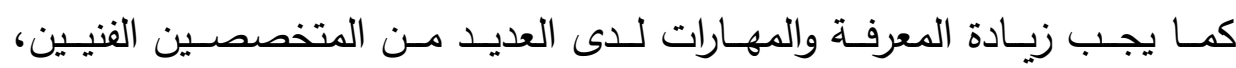
والمهندسين، والفيزيائيين، والكيميائيين، والمعلمين، والإحصـائيين في البحث عن إجابات سليمة علميًا للعديد من الأسئلة الصعبة في مجال الصحة البيئية. وفي حين تجاهل هذه المطالب، فإن الإنسان سيواجه مشاكل عدة منها: الوهن المبكر , وقصـر العمر • وأخيرًا، يجب أن يعيش الإنسان في وئام مـع أشكال لا تعد ولا

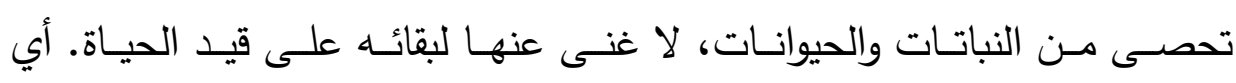
اضطرابات خطيرة في الأرض أو في النباتات والحيوانات تنتج في نهاية المطاف الاضطرابات في جسم الإنسان 24.

هناك أيضـا العديد من المخاطر التي نتجت من التحضر اللامسؤول والتي تهدد صحة الإنسان ووجوده, فعلى سبيل المثال أصبح الإشعاع المؤين هو أخطر تهديدًا لبقـاء الإنسـان؛ فالأشـعة المؤينـة ترتبط بعدد مـن المخـاطر الدقيقـة التي تستدعي القلق العام, "حيث أصبحت مصـادر الإشعاعات المؤينـة أسرع وأكثر انتثـارًا علـى نطـاق واســع", وتسـتخدم فـي أعـداد متزايـدة مسن المستثـفيات، والصناعات، والمؤسسات البحثية. ومن المؤكد أن الإشعاع المؤين قد يؤثر على نى بيئة كل فرد من أفراد المجتمع, فالعناصر المشعة هي من بين أكثر المواد السمية فتكًا في بيئة الإنسـان, إذتستخدم على نطاق واسـع في المختبرات والمستشفيات والصناعة, مـا بين تجارب الأسلحة النوويـة وتفريخ حطامها الإشعاعي في التربـة والمياه والغـلاف الجوي، أو التي تتتج كميات هائلة من النفايات المشعة للغاية سنويًا, وكذلك الحيوانات التجريبية اللازمـة لإجراء مزيد من البحوث تشمل حاليا كل البشرية، إلى جانب المخبر الإشعاعي الحديث الذي يشمل كامل الأرض. لكن العديد من الأسئلة الخطيرة بقيت دون إجابة. هل نستخدم الإشعاع بحذر واحترام 
يستحقه؟ إلى أي مدى تلوث البيئة؟ في أي اتجاه نحن ذاهبون؟ وإن لم يتم الإجابة

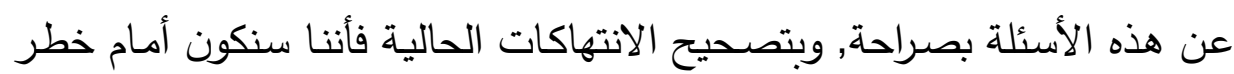
حقيقي 25.

كذلك فإننا نواجه بشكل دائم أخطارًا بعيدة المدى تتشأ عن استخدامات الطاقة النووية في أوقات السلم, حيث تنتج صناعة الطاقة النووية الكثير من مواد النفايات كل عام. قد تحتوي النفايات "عالية المستوى" الناتجة عن إعادة معالجة الوقود النووي المستهلك جزئياً على عدة آلاف من المواد المشعة الضارة, وقد ينتج عن استخدام التربـة, والغـلاف الجـوي, والمسطحات المائيـة في التخلص مـن النفايات النووية اختلالات بيئية خطيرة تؤثر في نهاية المطاف على الإنسان 26. وهنا يؤكد موري بوكتثين إنه إذا كانت مفاعلات الطاقة هي مصدر الطاقة

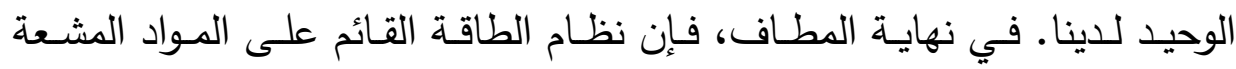
سيؤدي إلى تلوث البيئة على نطاق واسع في البداية في شكل محدود، ولكن في لهي

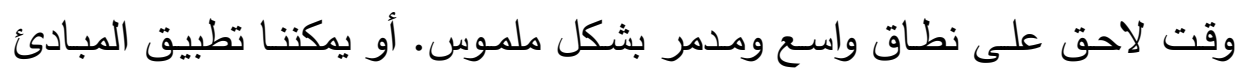

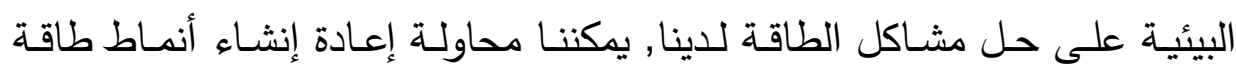
إقليمية سابقة، باستخدام نظام الطاقة المشترك الذي توفره الرياح, والمياه, والطاقة

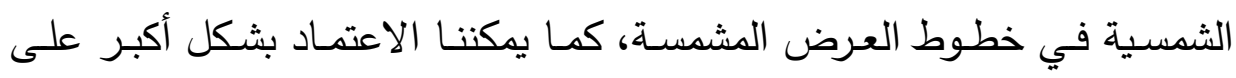

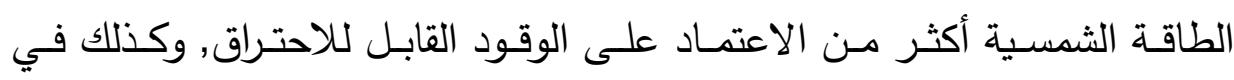

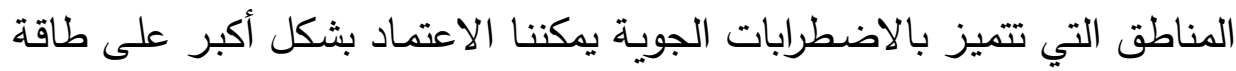

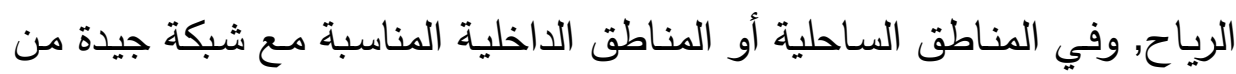

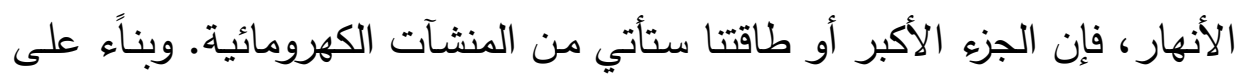

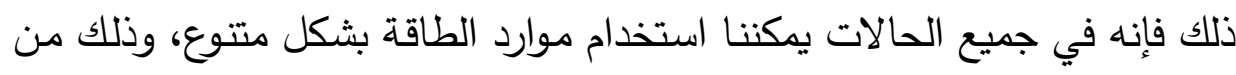
خلال تنظيمها في نمط متوازن بيئًا، حيث يمكننا الجمع بين طاقة الرياح والطاقة 
الثمسية والمياه في منطقة معينة لتلبية الاحتياجات الصناعية والمحلية لمجتمع معين, ومن ثم استخدام الحد الأدنى من الوقود الضـار . وفي نهاية المطاف، قد نطور أجهزة الطاقـة غير القابلـة للاحتراق إلى مرحلـة يمكن معها التخلص من جميع مصادر الطاقة الضارة 27. يتضـح من ذلك كله أن من أكبر مخاطر التحضر المبالغ فيه التقدم التقني اللامسؤول, فإن الأدوات التي صممتها عقولنا, وقد خلقتها أيدينا بسهولة لها نتائج كارثية على رفاهيتنا. وفي حقيقة الأمر نحن ألزمنا أنفسنا- من أجل بقائنا أجناسًا حيّة- بشكل لا رجعة فيه بالنظم المدمرة للإنتاج الضخم ومشكلات التلوث البيئي واسعة الانتشار • يبدو أن البشرية الآن تشعر أن التكنولوجيا قد عرقلتها فقد حولتها إلي ضـحية بـدلا من أن تستفيد منهـا. إن التكنولوجيا الحاليـة قد وضـعت قفصًا ذهبيا فوق الملايين المختقة الذين يحيون الآن في ضـجيج المدن السريعة في

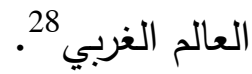
وهنا يظهر تناقض الصورة الكلاسيكية للتقنية مع الصورة الحديثة للتقنيات, إذ لا يقتصـر هدف التكنولوجيا فيمـا مضسي على مجرد "العيش بشكل جيد", أو العيش في حدود معينة, فقد كانت التقنية تشمل العيش بحياة أخلاقية وفقا لمبدأ أصلي ومنظم, وتُصَوَّر بأنها وسيلة, وإذا نظرنـا إلى التكنولوجيا بالمعنى المفيد، فإنها لا تشمل فقط المـواد الخـام والأدوات والآلات والمنتجـات، بـل أيضـا المنتج المختار والفائدة التي ستعود علـي الفرد والمجتمـع مـن إنتاجـه, وظـائف الإنتاج الصناعي الحديثة هي بالضـبط الطريقة المعاكسة, ومن ثم فإن الصـورة الحديثة للتقنية تقتصـر على مجرد تقنيات بالمعنى الآلي، ولكن أهدافـه مرتبطة ارتباطًا

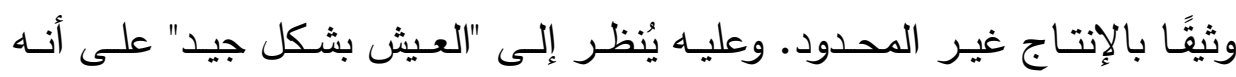
استهلاك غير محدود في إطـار مستوى غير أخلاقي ومخصـضص تمائا مـن 


\section{مجلة وادي النيل للاراسات والبحوث الإنسانية والاجتماعية ـ مجلة علمية محكمة}

(ISSN : 2536 - 9555)

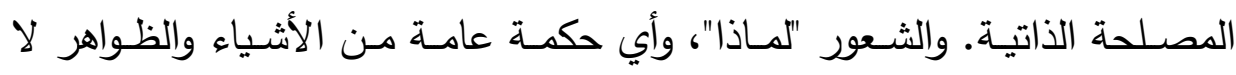
مكان لها في العالم تتطلبه الصناعة الحديثة. ما يهم حقا في التقنيات هو الكفاءة

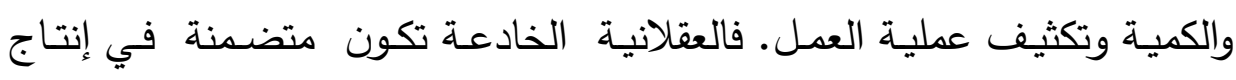
الموضوع الذي يكون مترتبًا على إضفاء الطابع العقلاني علي الذات بالدرجة التي

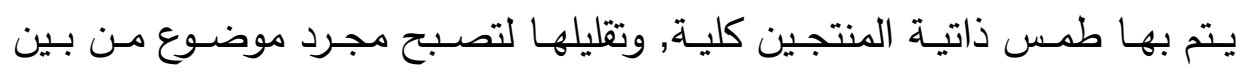
الموضوعات

في الوقت الحاضـر، نحتاج إلى صورة أوضـح عن المقصود بـ "التقنيات", ومشاكل الحساسية التي تثيرها، والوظائف التي تؤديها، وبالطبع المخاطر والوعود التون

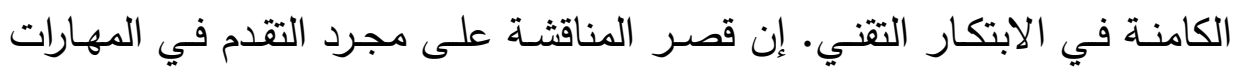

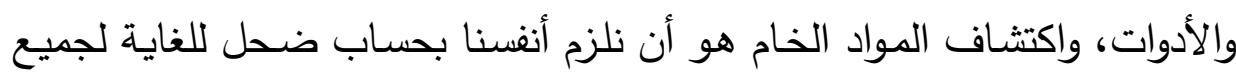

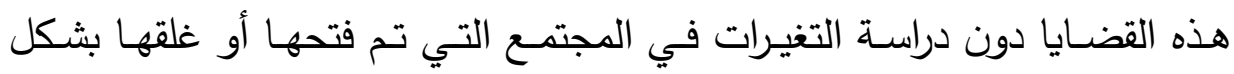
مختلف للابتكار التقني، وسنجد صعوبة كبيرة في تفسير سبب فثل مجموعة كبيرة

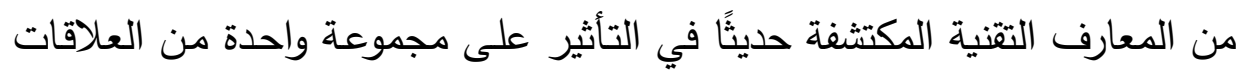
الاجتماعية، ومع ذلك يبدو أنها "تحدد" شكلها في مكان آخر أو في وقت فيت آخرما

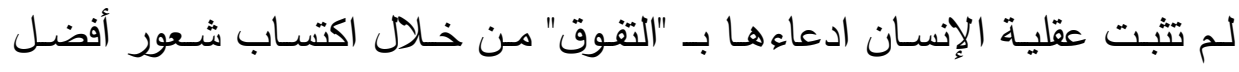

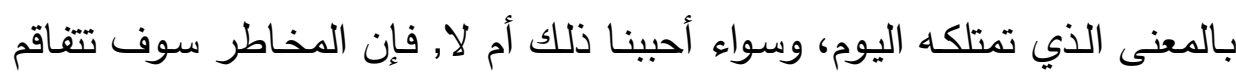

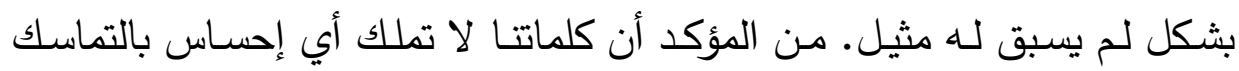
والمصير، بخلاف الادعاء المزيف بـ "التقوق" الذي يتجاهل تماما مسؤولياتتا تجاه

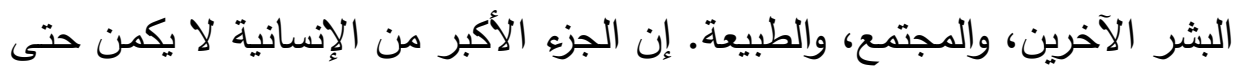

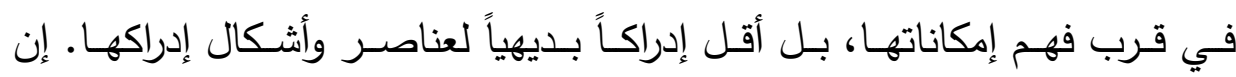

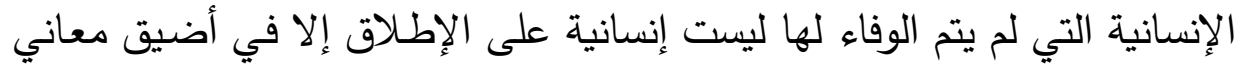

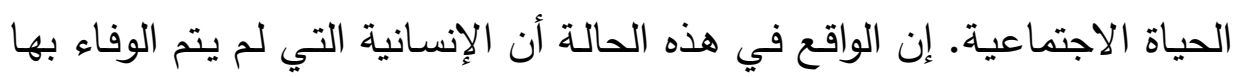


هي أكثر إثارة للخوف من أي كائن حي، لأنها لديها ما يكفي من تلك العقلية التي تسمى مجرد "ذكاء", لتجميع كل الظروف لتدمير الحياة على كوكب الأرض 30. إننا نفتقر إلى الإحساس بالمصفوفة الاجتماعية التي يجب أن تكون فيها جميع التقنيات جزءًا لا يتجزأ من المعنى الاجتماعي. إن التقنيات الآن في حاجة ماسـة إلى توقيف تقدمها، وإعادة تعريف أهدافها، وإعادة تتظيم أشكالها، وتغيير أبعادها فوق كل شيء، وإعادة استيعابها مرة أخرى 31. وهنا يؤكد موري بوكتشين إن أهم ميزة للتقنيات في التركيب الاجتماعي ما قبل الصناعي هو المدى الذي تكون فيه عادة متكيفة وليست مبتكره. عندما تكون الثقافة غنية بالبنية الاجتماعية وتتمتع بثروة من العلاقات الإنسانية، والمسئوليات المجتمعية، ومجموعة مشتركة من الاهتمامات المشتركة، فإنها تميل إلى تشكيل مجموعة تقنيات مفيدة وليس مجرد النهم من التطوير , لقد كانت هذه المجتمعات تميل إلى تطوير التقنيات بقدر كبير من الحذر والحساسية الثديدة لمدى إمكانية دمجها في المؤسسات الاجتماعية القائمة32. وهنا يتقق موري بوكتثين مع الكثير من المفكرين الذين نبهوا إلى مخاطر التقدم المبالغ فيه واللامسؤول, ومن بينهم برتراند راسل (Bertrand Russel) (1872-1970) الذي أكد أن العلم الحـديث يمكن الاسـفادة منـه فقط, إذا تـم استعماله بروح إنسانية, واذا اصبح متفهما لمنابع الحياة والسعادة, ودون هذا الفهم الصحيح للعلم, فإننا نخلق بغفلتنا سجنًا جديدًا لن يتبق فيه إلا مـا هو موحش, وكئيب, وميت روحيًا

كمـا أنـه يتفق مـع كل مـن مـاكس هوركهايمر (Max Horhheimer)

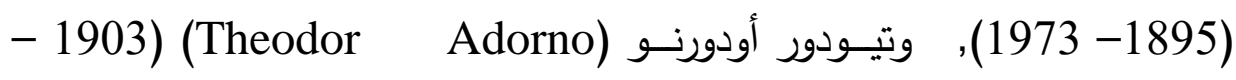
1969) اللذين أكدا على أن هذا التقدم اللامسئول قد حول الإنسان إلى مجرد 
شيء من الأشياء, فقد أصبح مثله مثل الآلّة, وقد نتج عن ذلك مخاطر جسيمة

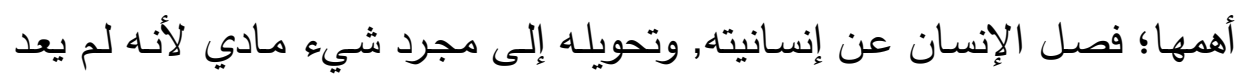

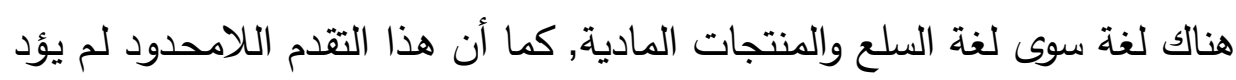

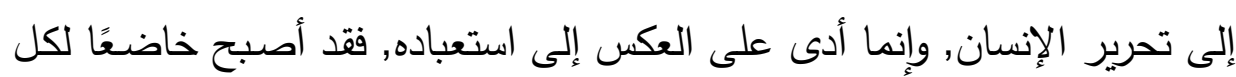

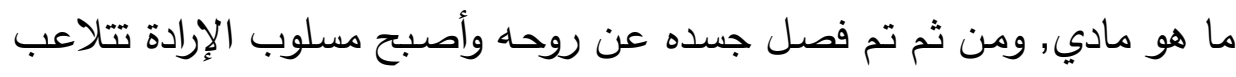

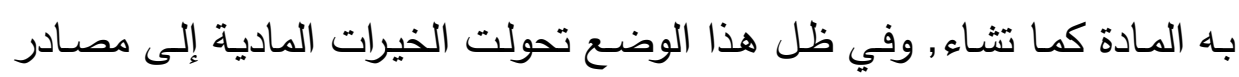
شقاء

كما أنه يتفق مع هربرت ماركيوز (Herbert Marcuse) (1898-1979) الذي انتقد بثدة التقدم المبالغ فيه, والذي تحول معه الإنسان إلى آلة صماء , حيث

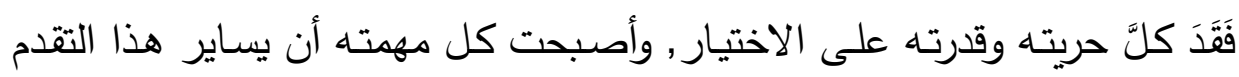

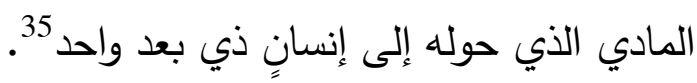
ويتقق كذلك مع جون ديوي (John Dewey) (1899 - 1952) الذي أكد

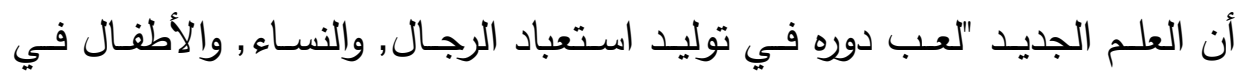
المصانع, وحافظ على الأحياء القذرة, والفقر المدقع, والثروة الباهظة, والاستغلال

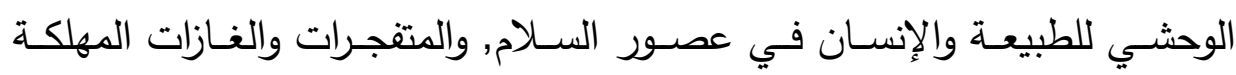
الضارة في عصور الحرب"36.

ويتفق كذلك مـع إريك فروم (Erich Fromm) (1900 - 1980) الذي

أكدأنه بالرغم من أن الإنسان اليوم قد وصل - كما يبدو - إلى بداية عهد جديد

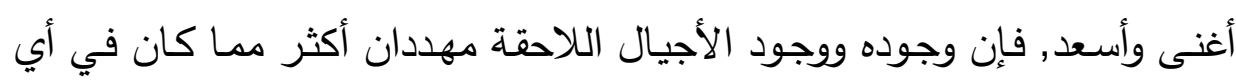
وقت مضى كما أنه يتفق مـع حنـة أرندت (Hannah Arendt) (1906 - 1975) التي أكدت أن هذا التقدم لم يؤد إلى حلى المشكلات الإنسانية, وإنما أدى إلى الى 
تفاقمها. ومـن أهم هذه المشكلات: انهيار أجهزة الخدمات العامـة مـن مدارس, وبريــ, وخدمات النظافـة, ووسـائل النقل وغيرهـا, ومشـاكل الانتقال داخل المدن, وتلوث البيئة في الجو والمياه كل هذا ليس سوى نتيجة حتمية لوضعية باتت معها الاحتياجات الحاسمة في المجتمعات الكبرى غير قابلة لأي تسيير وتدبير 38. ويتفق أيضـا مـع جاك أيلول (Jacques Ellul) ( 1912 ) الذي أكد أن المشكلة كلها تكمن في أسلوب تفكيرنا الحديث, ففي حقائق العالم والمجتمع نعمد إلى تفكيك روابط الأشياء التي باستطاعتنا تمييزها يقينًا, ونفصل بينها على حين أنها في واقع الأمـر لا تنفصل وتكمل بعضها ببعض؛ ومن ثم فإن باستطاعتنا فصل الفرد عن المجتمع, والأسطورة عن الحقيقة, والموروث عن التحديث, إضـافة إلى أن أسلوب تفكيرنـا اختزالي وأحسادي البعد, فنحن على استعداد لرؤيسة شيء

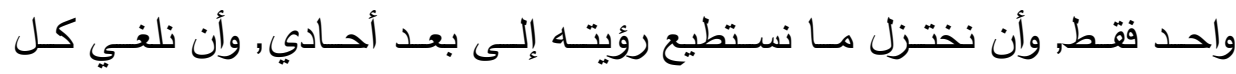
الصسوبات, والتفاصيل, والخاصيات المتفردة, الأمر الذي يعني أن تفكيرنـا حين شكلّه العلم والتقنية ـ لم يكن شاملاً ومعقدًا مثل الحقيقة, بل كان معوقًا 39. كما أنه يتفق مع إدغار موران (Edgar Morin) (1921 - 2001) الذي أكد أن التتمية التقنية قد عجزت عن تحقيق تتمية إنسانية مماثلة, والسبب في ذلك أن دعاة التنميـة يجهلون أن النمو التقني والاقتصـادي ينتج كذلك تخلغًا أخلاقيًا ونفسيًا, فـالإفراط في التخصص المعدم, وأشكال التجزيء في جميع المجالات, وكذلك الإفراط في النزعة الذاتية, وروح الربح والفائدة, كل ذلك يؤدي إلى ضياع التضامن الإنساني. والتتمية التي يطلقها العلم والتقنية تنطوي على تهديد بالإبادة (النووية والبيئية), وبسلطات رهيبة للتحكم (في الإنسان) ويتفق كذلك مع آلان تورين (Alain Touraine) (1925- 1958) الذي أكد أنه لم يعد لدينا ثقة في التقدم, ويزداد خوفنا أكثر فأكثر من أن تدمر التتمية 


\section{مجلة وادي النيل للاراسات والبحوث الإنسانية والاجتماعية ـ مجلة علمية محكمة}

(ISSN : 2536 - 9555)

التوازنات الطبيعية الأساسية, وأن تفرض على الجميع سباقًا مهلًًا تجاه التغيير , ولهذا يظهر خلف هذه المخاوف شك عميق ألا تكون الإنسانية بإزاء فض تحالفها مـع الطبيعـة, وتتحول إلى همجيـة في الوقت الذي تعتقد فيـه أنها تحررت مـن العوائق التقليدية, وأنها سيدة مصيرها ${ }^{41}$

ويتفق أيضا مع ميشيل فوكو (1926-1984) الذي أكد أن الحياة أدخلت

بشكل شامل في تقنيات تسيطر عليها وتديرها, وهي تقلت منها باستمرار, فالمجاعة موجودة على نطاق أكبر من أي وقت مضى, والمخاطر البيولوجية التي يتعرض لها الجنس أكبر وأكثر جسامة من أي وقت مضىى 42. وهنـا نأتي إلى التسـاؤل الحاسم هو: كيف سيكون بمقدورنا القضـاء على مخـاطر التحضـر المبـالغ فيـه واللامسؤول؟ ويجيـب مـوري بوكتشـين عـن هـــا التساؤل مؤكدًا أن السبيل الوحيد الذي يمكن التعويل عليه لتحقيق ذلك هو إعادة التوازن, والتفاعل, والتكامل بين البيئة الطبيعية والبيئة الإنسانية, وسيكون ذلك من خـلال الاعتمـاد على مـا أطلق عليـه اسـم البيئـة الاجتماعيـة فمـن خـلال البيئة الاجتماعية يمكننا النظر إلى الاضطرابات الهائلة التي تواجهنا الآن، وسيتضح لنا أن عصـرنا يحتاج إلى مجموعـة من المعـارف أكثر شمولا ونفاذا للبصيرة التي تكون علمية, إضـافة إلى كونها اجتماعية للتعامل مـع مشـاكلنا. وتباعًا لمـا سبق يجب علينـا دون التخلي عن مكاسـب النظريـات العلميـة والاجتماعيـة السـابقة، تطوير تحليل نقدي أكثر استتارة لعلاقتنا مع العالم الطبيعي, كما يجب أن نسعي إلى أسس النهج الأكثر ترميمـا للمشكلات الخطيرة التي تطرحها "التتاقضـات" الظـاهرة بـين الطبيعـة والمجتمـع, وكذلك يجب أن نجمـع نتـائج العلـوم المتجزئــة ونربط بينها ونراها في كليتهاإلى جانب خصوصيتها 
إن هدف البيئة الاجتماعية هو الكلية، وليس مجرد جمع تفاصيل لا حصر

لها مجمعة بشكل عشوائي وتقسيرها ذاتيًا وبشكل غير كافي, حيث يتناول العلم العلاقـات الاجتماعيـة والطبيعيـة في المجتمعـات و "النظم البيئيـة". وفي تصـورو للكلية فهذا يعني القول بالترابط المتبادل، فالبيئة الاجتماعية تسعى إلى كثف أشكال العلاقات المتبادلة أنماطها التي تعطي وضوحًا إلى المجتمع، سواء كانت طبيعية أو اجتماعية. والكلية هنا هي نتيجة لجهد واع لتمييز كيفية ترتيب تفاصيل المجتمع، وكيف أن "الهندسة" كما وضعها اليونانيون تجعل "كل شيء أكبر من مجموع أجزائه. وهنا يؤكد موري بوكتشين أن الكلية البيئية ليست تجانسًا ثابتًا, بل هي وحدة ديناميكيـة للتنوع. ويتحقق التوازن والانسـجام في الطبيعـة مـن خـلال التمايز المتغير باستمرار، ومن خـلال التتوع المتزايد باستمرار , ومن ثم لا يتحقق الاستقرار البيئي من خلال البساطة والتجانس, ولكن من التعقيد والتنوع, حيث لا تعتمد قدرة النظام البيئي في الحفاظ على سلامته على توحيد النظام البيئي ولكن على تتوعه

وبالتالي يجب السماح بقدر كبير من المساحة للعفويـة الطبيعية أي للقوى البيولوجية المتنوعة التي تتتج حالة بيئية متتوعة. فقد يتطلب "العمل مـع الطبيعة" أن نعزز التنوع الحيوي الذي ينبثق من التطور التلقائي للظواهر الطبيعية, لا يعني ذلك أنتا يجب أن نسلم أنفسنا إلى "الطبيعـة" الأسطوريـة التي تتجـاوز كل الفهم والتدخل البشري، وهي طبيعة تتطلب الخنوع البشري. يجب إدارة مستقبل العالم، وهذه الإدارة لن تكون مجرد لعبة شطرنج ولكنها أثبه بتوجيه القارب". إن ما نأمل أن تعلمه لنا البيئة الطبيعية والاجتماعية هو طريقة إيجاد التيار وفهم توجه النهر . ولكي يتحقق ذلك يوضـح موري بوكتشين أنه لا يمكن وصف النظم البيئية بشكل هادف بمصطلحات هرميـة. فـإذا أدركنا أن كل نظـام بيئي يمكن أن يُنظر إليه 
أيضًا على أنه شبكة غذائية، فيمكننا التنكير فيه على أنه ارتباط دائري ومتثابك

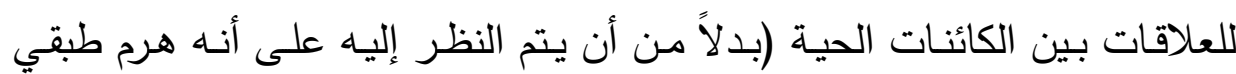
يهيمن عليه إحدى الكائنات)

والنتيجة التي يخرج بها موري بوكتشين هي أن تاريخ البشرية- منذ نشأتها-

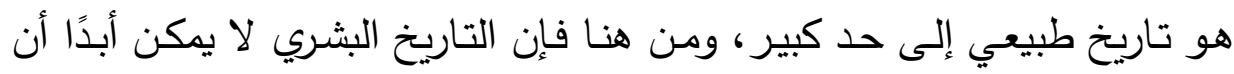
ينفصل عن نفسه أو ينفصل عن الطبيعة, وسيكون علينا بعد ذلك محاولة تحويل

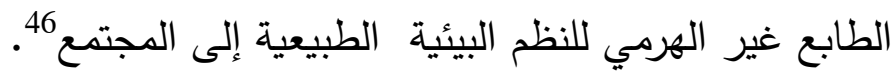

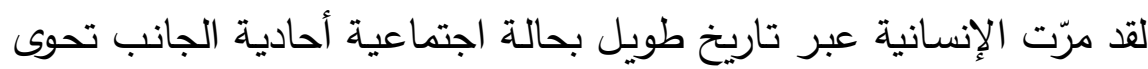

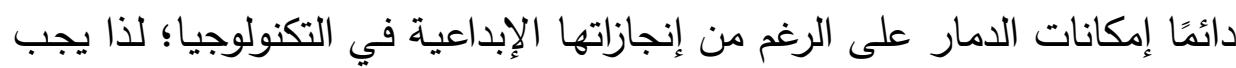

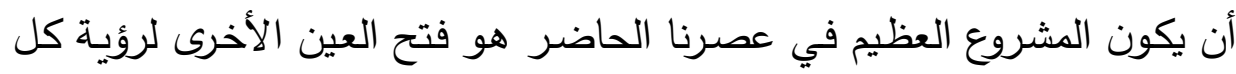

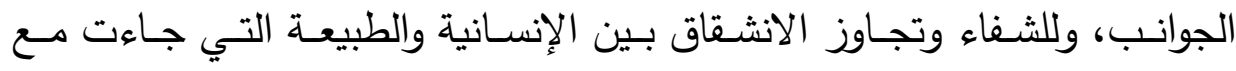

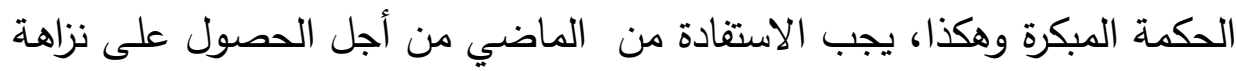

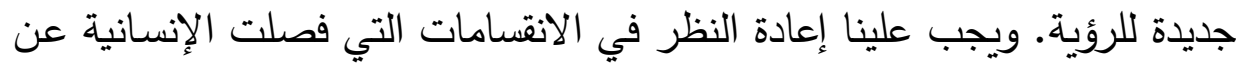

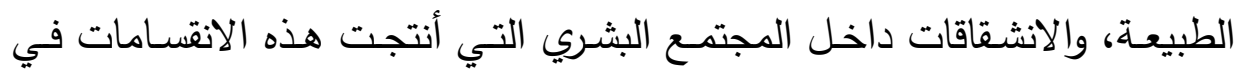

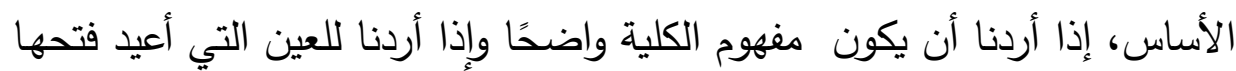
أن تبصر صورة جديدة للحرية

وتباعًا لذلك إما أن نتبع مسارًا نحو "تهاية التاريخ" القاتمـة، حيث يحل تتابع

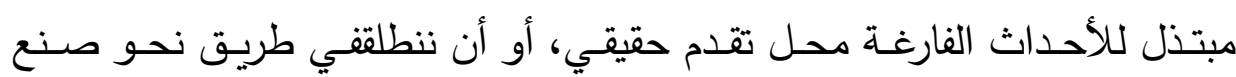
التاريخ الحقيقي، الذي فيه إنسانية بحق, ونتقدم نحو عالم عقلاني 48. 


\section{2- الجتتمع المدني في هقابل الدولة المركزية}

بعد أن تحدثا عن الخطوة الأولى نحو مجتمع بيئي إنساني والمتمثلة في

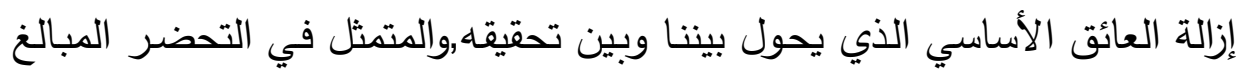

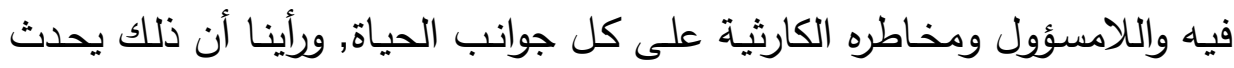
من خلال إعادة التوازن والتكامل والتفاعل بين البيئتين الطبيعية والإنسانية, ورفض الهيمنة والرؤي الأحادية. نتساءل ما نوع المجتمع الذى سيكون مهينًا لتحقيق هذا

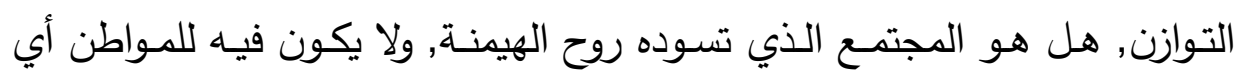

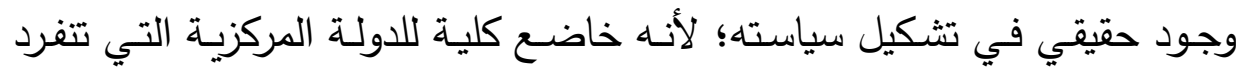
بالسلطة, والتي تكون صـاحبة القرار الوحيد في صنع السياسـة الملائهـة؟ أم أنـه المجتمع المدني الذي يكون فيه للمواطن دور حقيقي, ويكون صـاحب السلطة

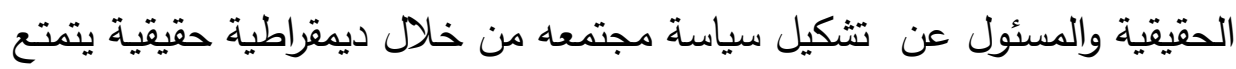

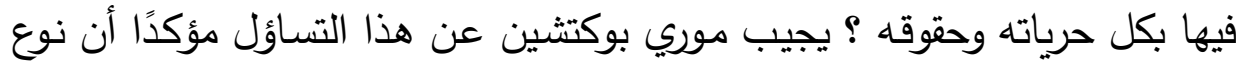

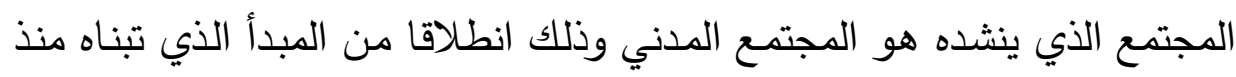

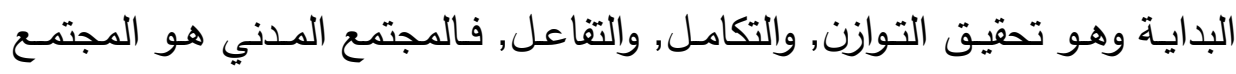
الوحيد الذي تتحقق فيه هذه الروح, وهو طريقنا نحو مجتهع بيئي إنساني إنـا

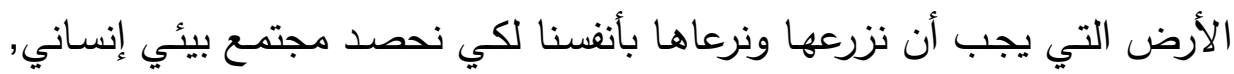

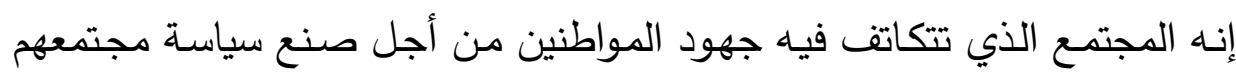

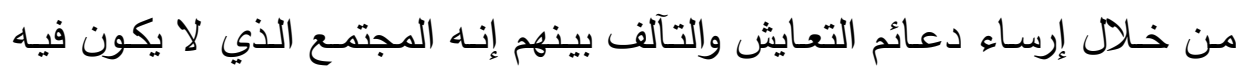

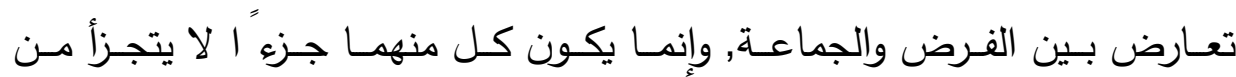

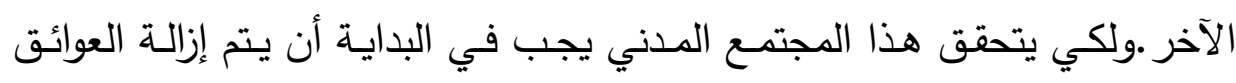

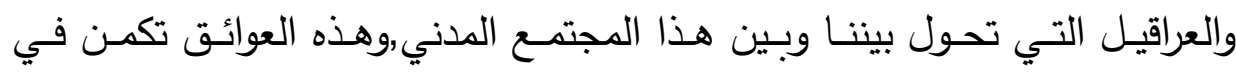
المساوئ التي نعاني منها في وقتنا الراهن, والتي يمكن إرجاعها جميعا إلى الهيمنة 
والرؤية الأحادية التي تفرضها الدولة المركزية, وما نتج عنها من تدهور وانهيار على كل المستويات السياسية, والاجتماعيـة, والاقتصـادية, والبيئية, والانسـانية.

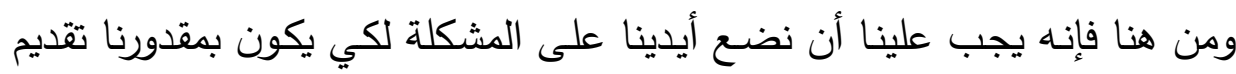
العلاج. يبدأ موري بوكتثين برسم صورة للمجتمع الراهن موضحًا مواطن القصور

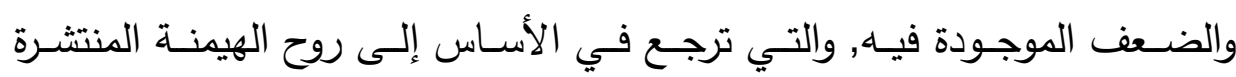

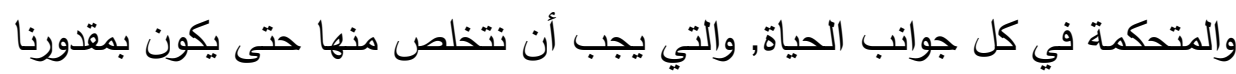

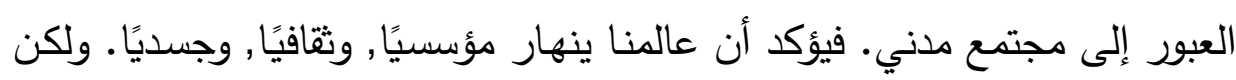

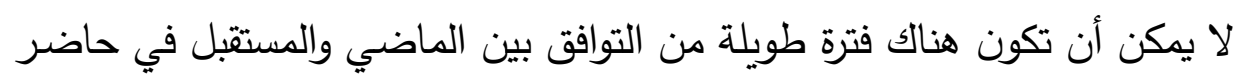

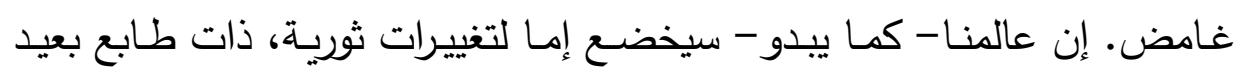

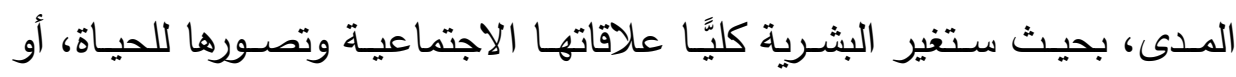
ستعاني من نهاية العالم التي قد تنهي حقًا البشرية على كوكب الأرضلقد دخلنا

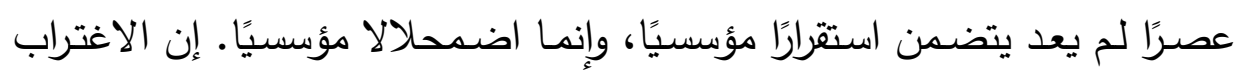

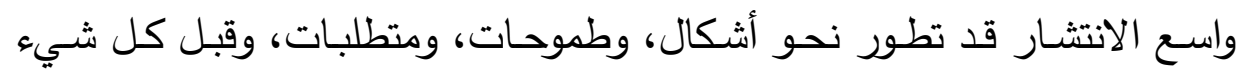

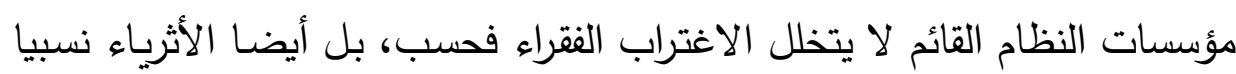

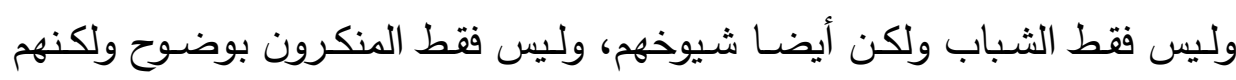

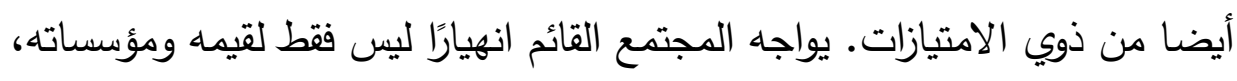

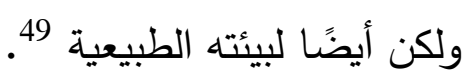

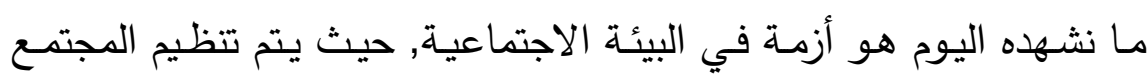

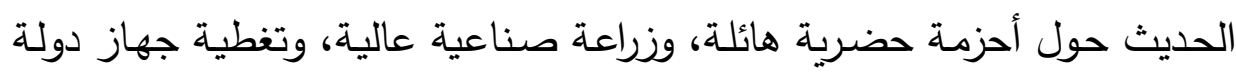
متضخم بيروقراطي مجهول الهوية إن عملية تبسيط البيئة وجعلها عنصرًا خاميًا

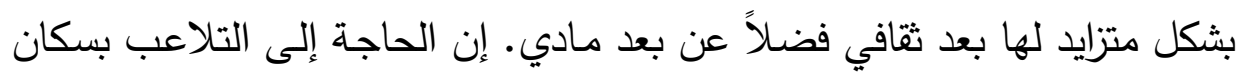


حضريين هائلين لنقل - وإطعام, وتوظيف, وتعليم, وتسلية ملايين من الأشخاص-

تـؤدي إلى تراجع حاسـ في المعـايير المدنيـة والاجتماعيـة. إن المفهوم الثـامل للعلاقات الإنسانية- الثمولية والمركزية- يميل إلى السيطرة على المفاهيم الأكثر تكرارًا في الماضـي. وكذلك الأسـاليب البيروقراطية لـلإدارة الاجتماعية تميل إلى استبدال المناهج الإنسانية. وكل ما هو عفوي، مبدع، ومحدود, وما هو مقيّد من قبل المعياري، والمنظم, والكتل, ودن ثم يتم تقليص مساحة الفرد بثبات من خلال القيود المفروضـة عليه من قبل جهاز اجتماعي غير شخصي مجهول الهويـة, ويتم تسليم أي اعتراف من الصفات الثخصية الفريدة على نحو متزايد إلى التلاعب في القاسم المشترك الأدنى للكتلة. إن النهج الإحصـائي الكمي - طريقة خلية النحل في التعامل مـع الناس- يميل إلى الانتصـار على النهج الفردي والنوعي الثـين الذي يضع التأكيد القوي على التثرد الثخصي، والتعبير الحر، والتعقيد الثقافي 50. إن المدينة والولاية الحديثة، والتقنية الهائلة للثورة الصناعية، وأنظمة الإنتاج الأكثر عمقاً، وأكثر عقلانيـة، وأنظمـة خطوط التجميع لمنظمات العمال، والأمـة المركزيـة, والدولـة وجهازها البيروقراطي قد وصلت إلى حدودها القصـى. ومهـا كان دورهم التدريجي أو التحرري الذي قد تمتعوا بـه، فقد أصسبحوا الآن يتسمون بالقهع. إنهم يتراجعون ليس فقط لأنهم يضعفون الروح البشرية, ويصرفون المجتمع من جميع معايير التماسك, والتضـامن, والمعايير الثقافية الأخلاقية, فهي تراجعية من وجهة نظر موضوعية، من وجهة نظر بيئية. لأنها تقوض ليس فقط الروح البشرية والمجتمع البشري, ولكن أيضـا سـلامة كوكب الأرض, وجميع الكائنات الحية الموجودة بداخله

وعـادة مـا تأخذ علاقتتـا اليوم بالمدينـة شكل متطلبـات ماديـة للغايـة, إذ إن المدينة الحديثة يتم تقييمها من خـلال الخدمات المادية التي تقدمها لسكانها. إن 
السـات الدينيـة, والثقافيـة, والأخلاقية, والبيئية التقليديـة التي كانت في الماضـي تربط المواطنين بمدينتهم قد انحلت إلى معايير كمية، ومحايدة أخلاقياً في كثير مـن الأحيـان؛ لذا تعد المدينـة أول صـندوق نضـع فيـه سلسـلة مـن الاسـتثارات الاجتماعيـة لغـرض صـريح يتمثل في الحصـول على عـد مـن العوائد الماديـة المميزة

وفي هذا الإطار فإنه من غير المتوقع أن يتدخل المواطن في صنع سياسة مجتمعه. ولا تشجعه البيئة الحضرية المعاصرة على فعل ذلك. "فالمواطن الصـالح" هو الشخص الذي يطيع القوانين، ويدفع الضرائب، ويدلي بصوته بشكل طقوسي للمرشحين الذين تم اختيارهم، و"يمارس نشاطه التجاري الخاص". وهنا يعترف دافعو الضـرائب والمسـؤولون الحكوميون بـأن المـواطنين يجب أن يكونـوا ممثلين بشكل صحيح بواسطة كوادر فعالة، ومتخصصة ومهنية, بيد أن السلطة اليومية تتواجد على وجه التحديد في أيدي هؤلاء الوكلاء الإدارين، وليس في "دوائرهم الانتخابية" الذين يكتسبون بشكل متزايد إخفاء الهوية وعدم الوجود الذي تشير إليه كلمة "الدائرة الانتخابية؛ لذا فإن مفهوم المواطنة محفوف بعواقب نفسية وعواقب سياسية خطيرة, فالأفراد الذين يتقلص وضعهم الاجتماعي لمجرد دافعي الضرائب والإدلاء بأصــواتهم فـي الانتخابـات يميلـون إلـى تكـوين صــور سـلبية للغايـة لشخصياتهم وللبيئة الطبيعية المحيطة بهم. ومن ثم يصبح المواطن المستضعف بشكل متزايد هادئًا ومنعزلًا بشكل كبير , ومن ثم يفقد مكانته الاجتماعية, وبمرور الوقت يصبح أقل من إنسـان، حيث يفقد الفرد إحساسـه بذاته,وبذلك يتم تجريـ الفرد من سلطة التصرف,ويتزايد عنده إحساس متعاظم بعدم الكفاءة الثخصية, ومن ثم يصبح التقاعس هو الثكل الوحيد للعمل مـع النتيجـة التي يتراجع بهـا "المكون" إلى انعدام داخلي يفتقر إلى الجوهر ليجعل المرء يعمل بشكل فردي 53. 
وتباعًا لذلك فإن الآثار النفسية لهذه السُبل مؤسفة للغايـة بنفس تأثيراتها

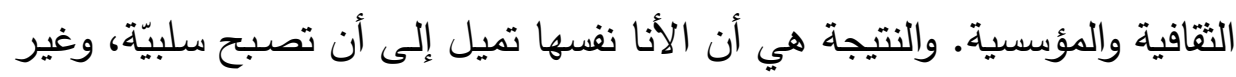

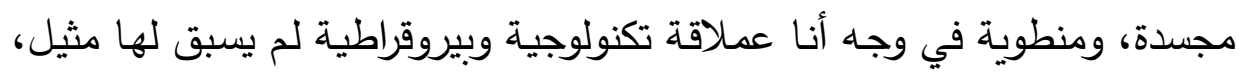

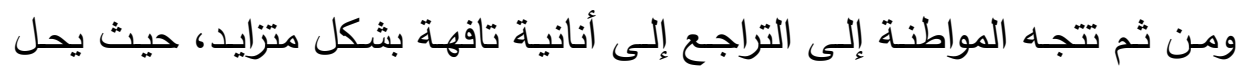

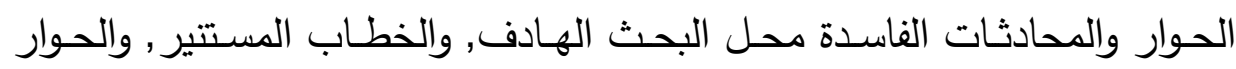
البناء. ولا يقتصر ذلك على الأفراد العاديين، وإنما يمتد ليشمل المفكرين والفنانين

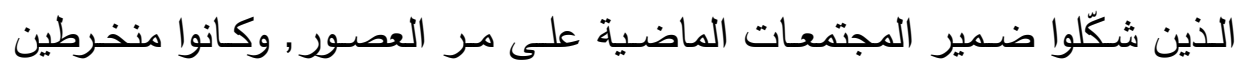
بشكل عميق في الحياة العامة, كالمحفزات الرئيسة لتحقيق المجتمع الجيد. وجملة القول مثل أولئك المفكرين الاجتماعيين الذين تراجعوا إلى الحدود الأكاديمية

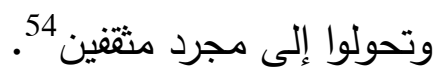

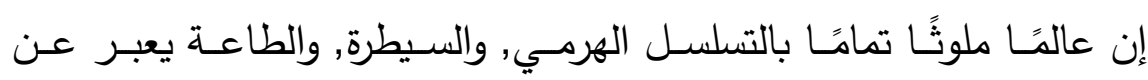

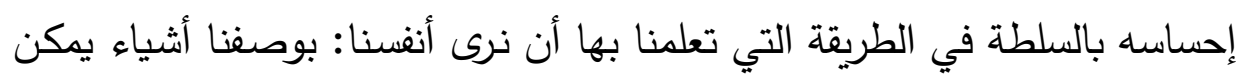

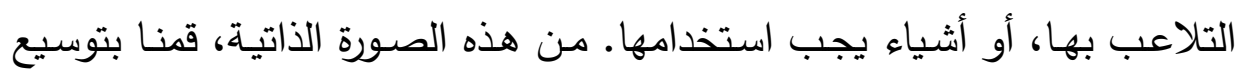

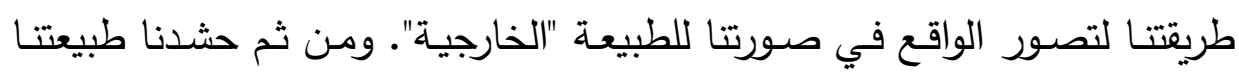

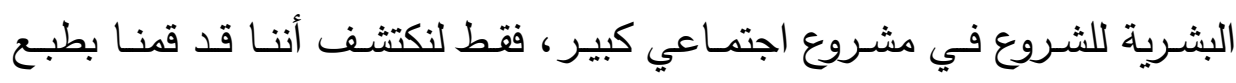

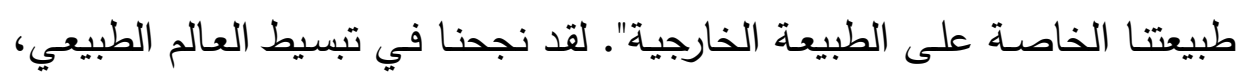

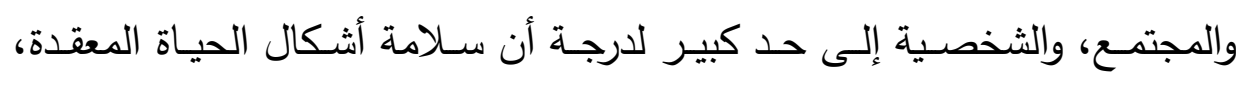

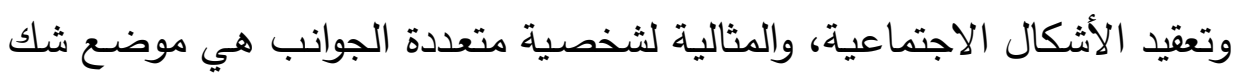
بالكامل

وفي هذا الإطار تظهر الدولة المركزية المهيمنة العائق الأساسي الذي يحول

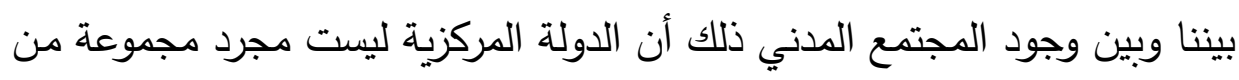

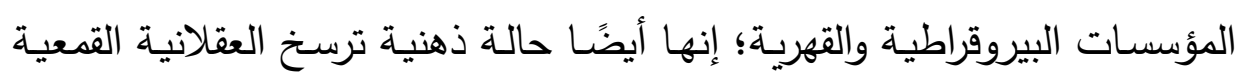




\section{مجلة وادي النيل للاراسات والبحوث الإنسانية والاجتماعية ـ مجلة علمية محكمة}

(ISSN : 2536 - 9555)

من أجل تتظيم الواقع, إن أسطورة الدولة القهريـة المنتشرة في كل مكان هي قصـة تخدم جهاز الدولة بشكل جيد من خلال خلق شعور بالرهبة والعجز في المظلومين الذي ينتهي بالتهئة الاجتماعية. تلك الرهبة واللامبالاة في وجه سلطة الدولة هي نتاج التكييف الاجتماعي الذي يجعل هذه السلطة ممكنة. لقد غزت الدولة الحديثة الحياة المجتمعية بالكامل، بوسـائلها الإعلامية، وأنظمـة المراقبة المتطورة للغاية، وسلطتها للإشراف على كل جانب من جوانب الحياة الشخصية تقريبًا. لم تكن الدولة- في الثكل المستكمل بشكل نهائي- الذي وجدناه اليوم قد نشأت إلا بعد أن أعيدت صياغة المجتمعات,والعادات, والحساسيات التقليدية بشكل دقيق بحيث تتقق مع الهيمنة التي فقدت البشرية كل شعورها بالتواصل مـع المجتمع العضوي الذي نشأت منـه

ويمكن الآن استخدام التعاليم الأخلاقية لإخفاء إفساد المجتمع العضوي من

خلال جعل القيم الاجتماعية موضوعًا لمعايير أيديولوجية وليست عملية. وبمجرد أن تكون الأفعال قابلة للتحويل من العالم الحقيقي إلى هذا العالم الغامض، فإن هوصن قواعد المجتمـع ستكون حرة لتحريف الواقع نفسه وإخفاء التتاقضـات التي ظهرت الآن في المجال الاجتمـاعي, وفي نهايـة المطاف ستخترق الدولـة غـلاف النفس البشرية وتؤسس داخلها قوى باطنية من الإكراه والقيد 57.

ومـن هنـا فـإن قدرة الدولـة على اسـتيعاب الوظـائف الاجتماعيـة لا تـوفر

لوجودهـا مبررات إيديولوجيـة لوجودهـا فقط, وإنمـا تعيد ترتيب الحيـاة الاجتماعيـة

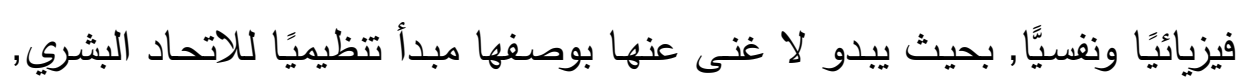
بعبارة أخرى فإن لدى الدولة نظريات خاصـة بها، هي نظريات سياسية مطبوعة على النفس والعقل, مع التقنيات "العلاجية" المناسبة لتكييف الفرد معهافي إعادة هيكلة المجتمـع حول نفسـه تحصـل الدولـة على وظـائف اجتماعيـة فائقـة النشـاط 
تظهر الآن بوصفها وظائف سياسية. لا تدير الاقتصاد فحسب بل تسيسه أيضاً. كما أنها لا تستعمر الحياة الاجتماعية فحسب بل تمتصهيا. وهكذا تظهر الأشكال

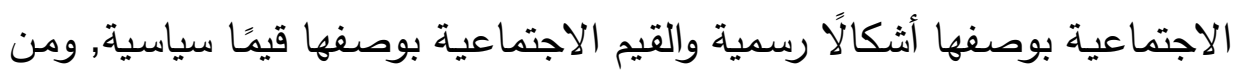
ثم يعاد تتظيم المجتمع بطريقة تجعله لا يمكن تمييزه عن الدولة.58. وهنا يرى موري بوكتثين أن السبب الرئيس وراء استمرار الخلط بين السياسة وسلطة الدولة بقوة اليوم, هو أننا فقدنا رؤيسة المصدر التاريخي والساحة الرئيسة الريسة

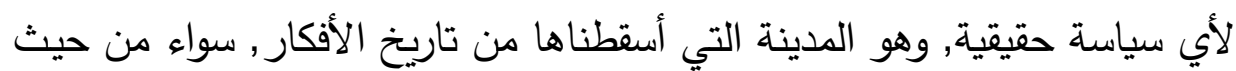
الطريقة التي يفسر بها الوضع الإنساني الحالي وأنظمة الحكم العام التي يخلقها.

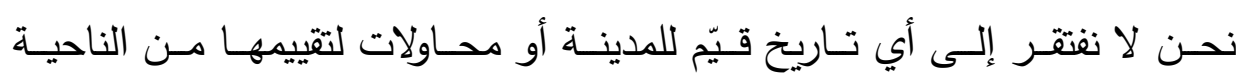
الاجتماعية, وإنما أدبنا الحضري بشكل عام يهمل العلاقة بين المدينة والظـاهرة

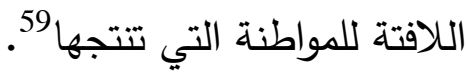
وإذا تساءلنا عن الاقتصاد المصاحب لهذه الدولة المركزية نجد أنه الاقتصاد

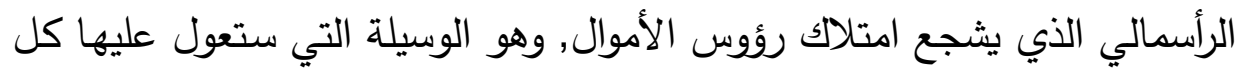
دولة لإثبات تفردها وتفوقها وفرض هيمنتها, فلم يعد السراء مطلبًا شخصيًا كما

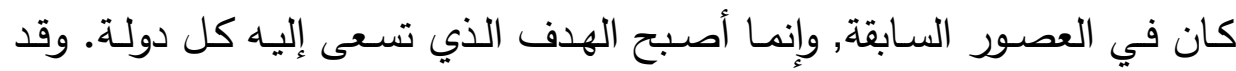
أصبح الاهتمام بالتجارة هو محور هذا الاقتصاد الرأسمالي, وتم في الدقابل التقليل

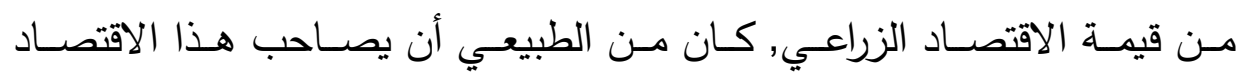

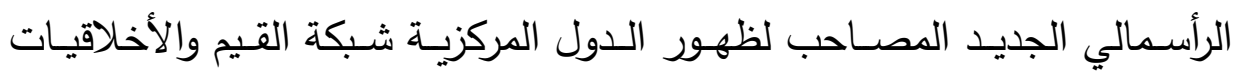

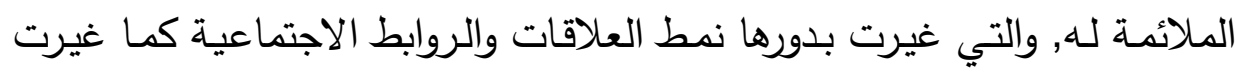
من شكل المؤسسات السياسية, ودور الأفراد في ظل هذه الأوضاع الجديدة, وفي ظل هذا الجو اختثت روح التعاون التي كانت تميز المجتمع المدني القديم, والتي لتي

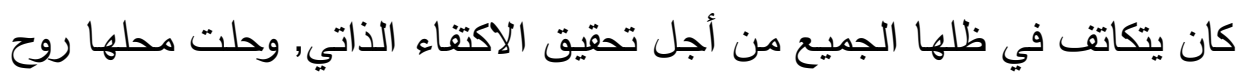




\section{مجلة وادي النيل للاراسات والبحوث الإنسانية والاجتماعية ـ مجلة علمية محكمة}

(ISSN : 2536 - 9555)

الأنانية وتفضيل المصالح الثخصية. وقد ظهرت النخب الثرية التي لا تسعى إلا

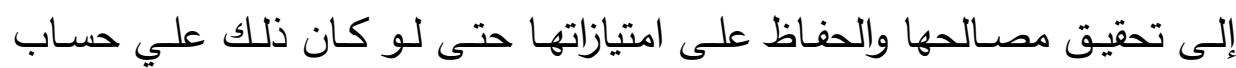
الفئات الأخرى الموجودة في المجتمع والتي تأثرت بالسلب نتيجة غياب الضوابط والمعاير التي كان يخضع لها المجتمع المدني فيما مضىى فئ.

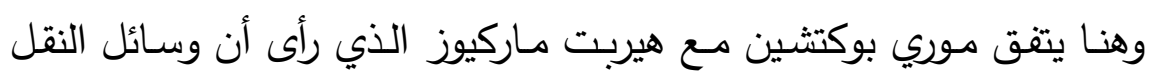
والاتصـال الجماهيري, وتسهيلات السكن, والطعام, والملبس, والإنتاج المتعـاظم

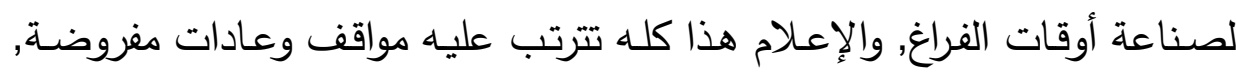

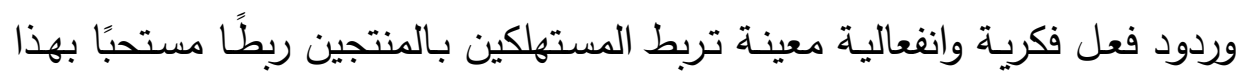
القدر أو ذاك, ومن ثم تربطهم بالمجموع, وهكذا يتكون الفكر والسلوك الأحادي البعد

ويتفق كذلك مع إريك فروم الذي رأى أنه قد أصبح قدر الإنسان أن يسهم أنها

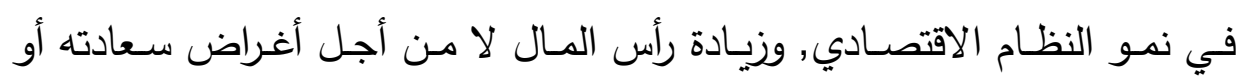

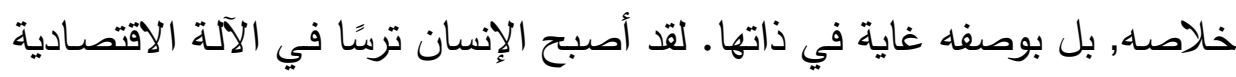

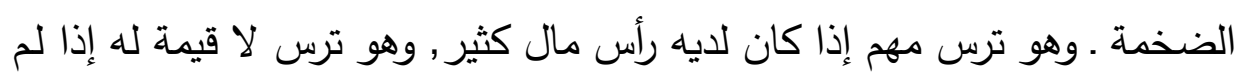

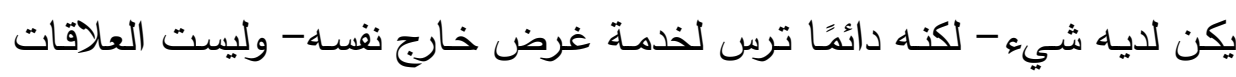

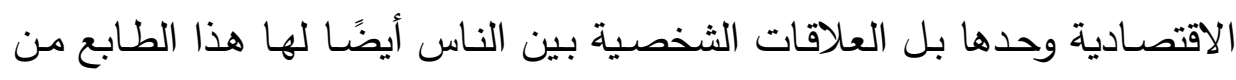

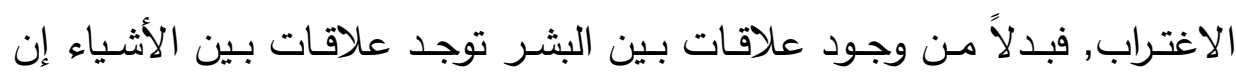

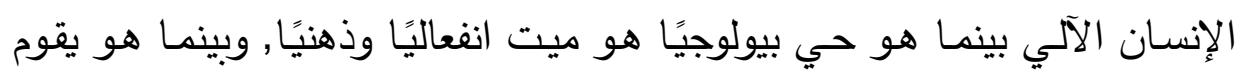
بحركات الحياة, فإن الحياة تتساب من بين يديه كالرمال فئ. وهكذا نحن نظهر الحاجة المتزايدة دائمًا من المزيد إلى الأشياء إلى المزيد من الاستهلاك. وباشتهائنا للاستهلاك فقد كل صلة بحاجات الإنسان الحقيقية,

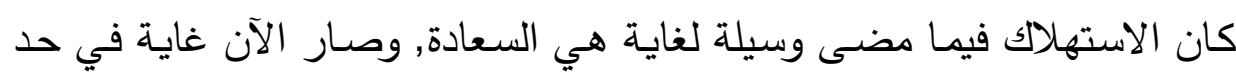


ذاتها, ومع تعدد السلع يتسع مجال الأشياء الغرببة التي تستعبد الإنسان ومن ثم

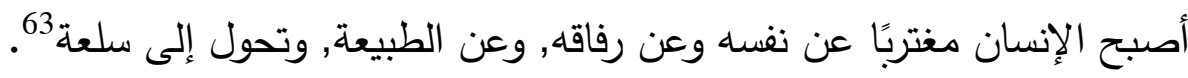
ويتفق أيضا مع آلان تورين الذي أكدأن الفردية سرعان ماتثظت إلى عدة حقائق أظهر لنا أحد أجزائها "أنا" هشة متقلبة خاضعة لكل الإعلانات, والدعاوات, وصور الثقافة الجماهيرية, بحيث لم يعد الفرد سوى شاشة تعرض عليها رغبات, وحالات, وعوالم خيالية مفبركة في مصانع الاتصالات الجديدة.64. بحتئ. ويتقق أيضا مع نعوم تشومسكي (Noam Chomsky) (1928) الذي أكد أن التركيز على الاستهلاك قد أدى إلى خلق حاجات زائفة, وأدى إلى تتظيم العقل العام, كما أدى إلى إحداث "فلسفة لا جدوى", وانعدام الهدف في الحياة من خلال الهال

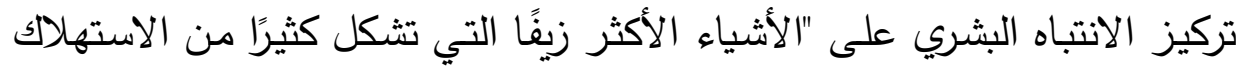

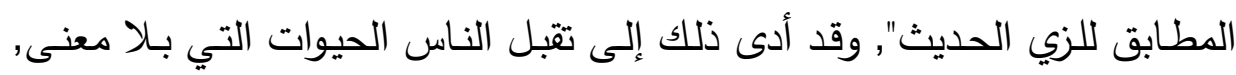

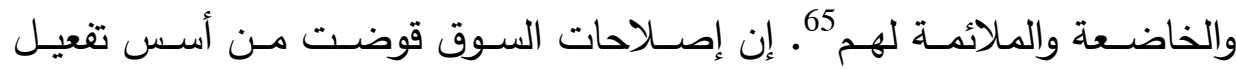

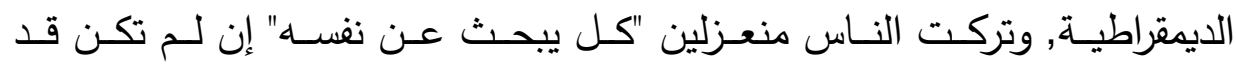

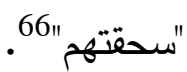

وبعد أن رسم موري بوكتثين صورة واقعيـة للمجتمع الحديث موضحًا أهم

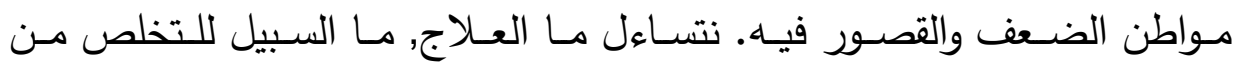
الأزمات والمشكلات التي يعاني منها مجتمعنا الراهن؟ وهنا يجيب موري بوكتثين

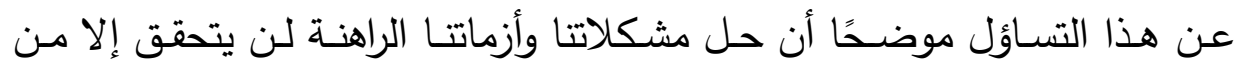

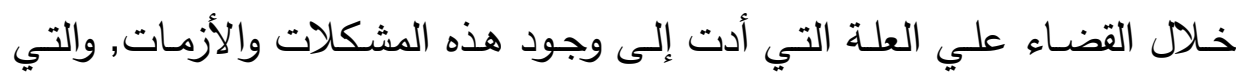
تكمن في الأساس في الهيمنة وإبعاد المواطن عن المشهـ السياسي والاجتماعي, الهاء وذلك في رأيه لن يتحقق إلا من خلال المجتمع المدني الذي سيعود فيه للمواطن دوره الحقيقي بوصفه صانع سياسة مجتمعه, ويمارس فيه ديمقراطية حقيقية قائمة 
على الحوار والنقاش البناء الذي يؤدي إلى البناء وليس إلى الهـم, ومتمتعا بكل

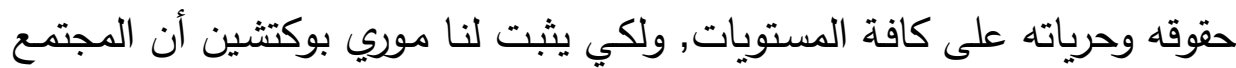

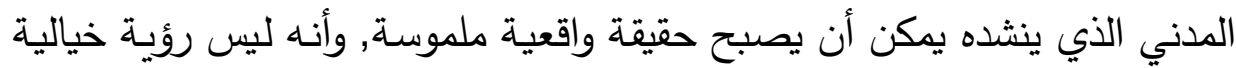

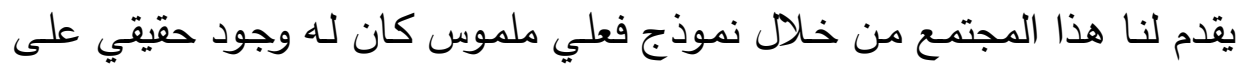

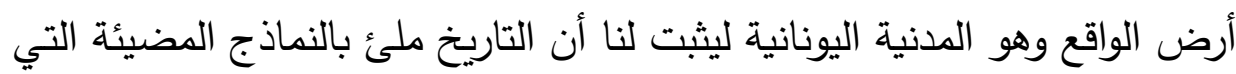

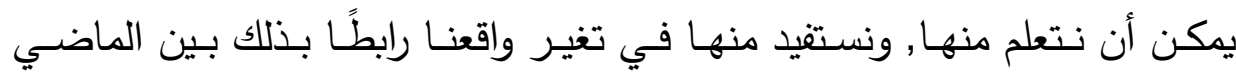
والحاضر والمستقبل, ومؤكدًا أن من لم يتعلم من الماضسي لا يمكن أن يتعامل لهـل بحكمة مع الحاضر , وبالتالي لا يجب أن ينتظر مستقبلاً مشرقًا.

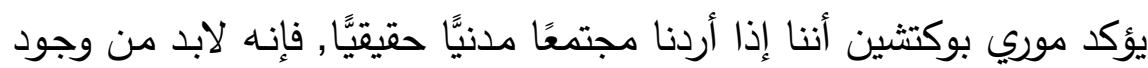
المواطن الذي ستقع على يديه مسؤولية خلق هذا المجتمع, حيث هذا المواطن هو

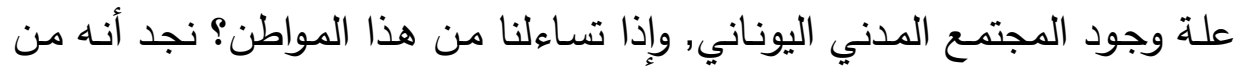
يمارس الحرية من خلال المشاركة في المؤسسات الحرة، ومن خلال إظهار نشاط

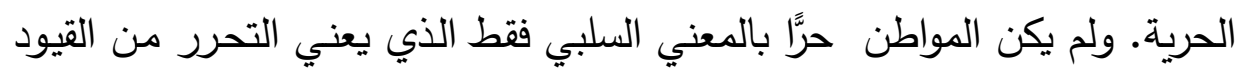

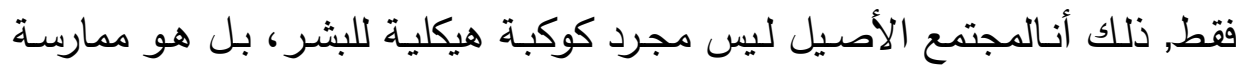

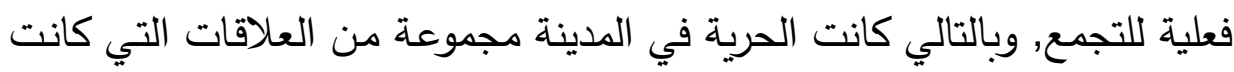
في طور التكاثر باستمرار

إن المدنية الآثينية بمؤسساتها الديمقراطية لها أهمية كبرى بالنسبة للتقاليد

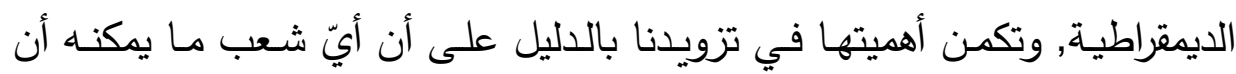

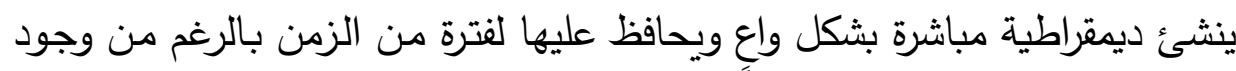
العبودية, والتفاوتات الاقتصادية والطبقية, والسلوك الاستبدادي, وحتى الإمبريالية التي كانت موجودة في أغلب أنحاء العالم القديم 68 
ومن هنا فإن لحظات التاريخ تشكل جدلًا واضحًا يفتح مجالًا تحرريًا يمكن من خلاله التحدث عن المواطنين بوصفهم كائنات حرة وعقلانية يمكن أن تحيا معًا. عـلاوة على ذلك كانت المدينـة ميدانًا أصيلًا للسياسـة بالمعنى الديموقراطي الهيليني للمصـلح. فالديمقراطية التي تم تصـورها على إنها ديمقراطية مباشـة تتطوي على الاعتقاد بأن جميع البشر "العاديين" مؤهلون لإدارة شؤونهم السياسية بشكل جماعي

كانت المدينة مجتمعًا بشريًا وأخلاقيًا وبيئيَّا فريدًا، غالباً ما عاش أعضـاؤها توازناً مـع الطبيعة, وأوجدوا أشكالاً مؤسسية تشحذ الوعي الذاتي للإنسان، وتعزز العقلانية, وتعزّز الفردية، وتتشئ أشكالًا مؤسسية للحرية

لقد تجمع الآثينيون لا لصياغة السياسات وإصدار الأحكام فقط؛ لقد اجتمعوا معـاً للتعلم المتبـادل بعضـهم مـع بعض في القدرة على التصـرف بشكل عـادل وتوسيع مبادئهم المدنية من الصـواب والخطأ. لم تكن "العملية السياسية"- التي تستخدم لغة مبتذلة حديثة- مؤسسية وإدارية بحتة, وإنما كانت العملية معقدة بشكل مكثف بمعنى أن السياسـة كانت عبارة عن "منهج" يومي لا ينضـب، مـن أجلـ النمـو الفكري والأخلاقي والعملي، والذي عـزز قدرة المـواطنين على المشـاركة الإبداعية في الثؤون العامة، لتحقيق أفضل قدراتهم للخدمة المدينة واحتياجاتها، ولإدارة شؤونهم الخاصة بذكاء وفقًا لأعلى المعايير الأخلاقية للمجتمع 71. ومن هنا يؤكد موري بوكتشين أن المواطنة الحقيقية قد تجسدت في أفضل صورها مع المواطنة اليونانية التي كان فيها المواطن دورًا حقيقيًا فعليًا في الرسم سياسـة مدينته وتثكيلها, حيث يشـارك على أرض الواقع في صنع كل القرارات السياسية لتحقيق الديمقراطية التي تجسدت في ممارسة فعلية تم التعبير عنها من خـلال الحـوار والنقاش في كل مـا يخص القضـايا العامـة, فقد سـاعد على ذلك 


\section{مجلة وادي النيل للاراسات والبحوث الإنسانية والاجتماعية ـ مجلة علمية محكمة}

(ISSN : 2536 - 9555)

الثقافة السائدة آن ذالك, والتي أعطت للتعليم دورًا رئييًا فكان المواطن يتعلم من

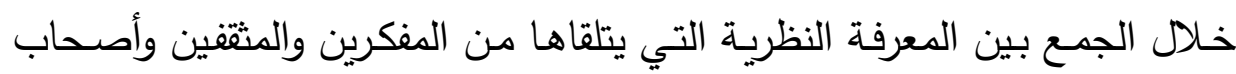

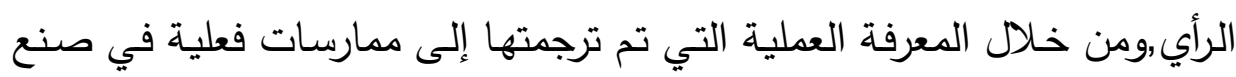

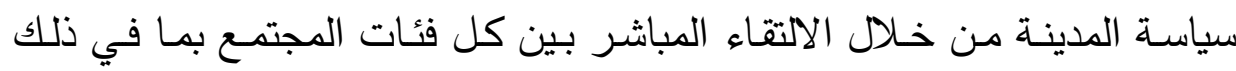
السياسيين, والفنانين, والمفكرين, وكل فئات المجتمع. وقد ساعد ذلك أيضا انتقال آثينا التدريجي من الحكم الأرستقراطي إلى الحكم الديمقراطي فقد أدى ذلك ولك إلى فئى

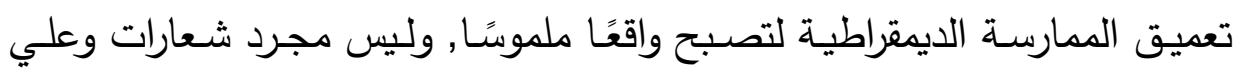

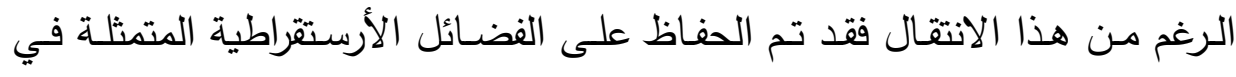

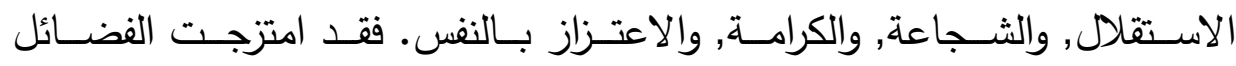

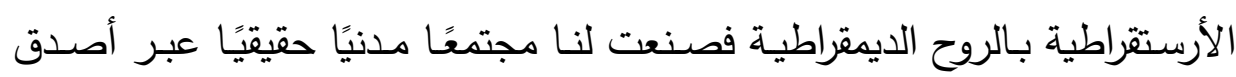
تعبير عن مواطنة حقيقية.72. وإذا كانت المواطنة هي الأساس الأول لوجود المجتمع المدني فإن الأساس

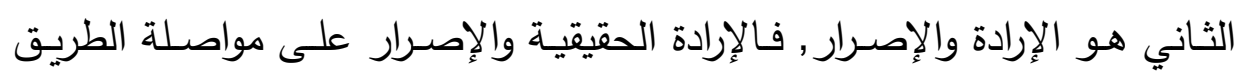

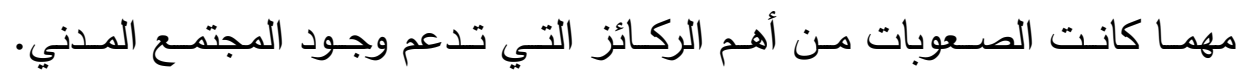

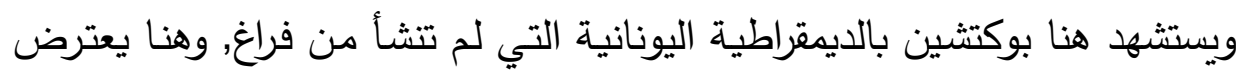

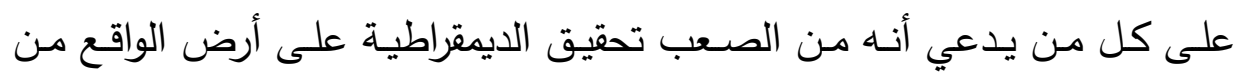

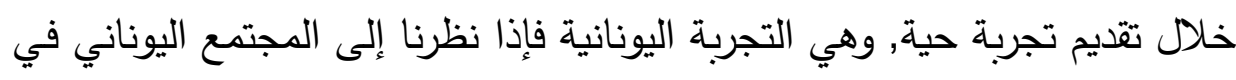

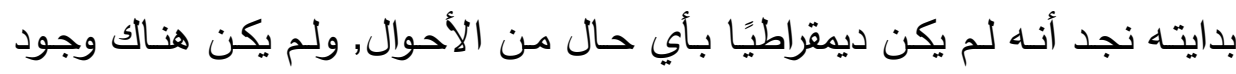
للمجتمع المدني الذي يكون فيـه للمواطن دور حقيقي في صنع سياسـة مدينته

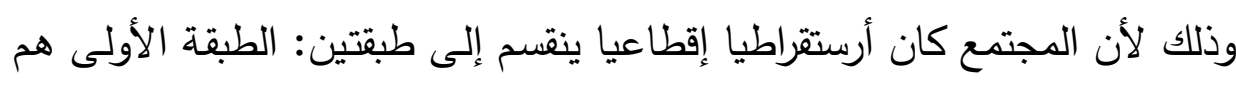
النبلاء الإقطاعيون الذين يتحكمون في كل شيء سياسيًا, واجتماعيًا, واقتصاديًا

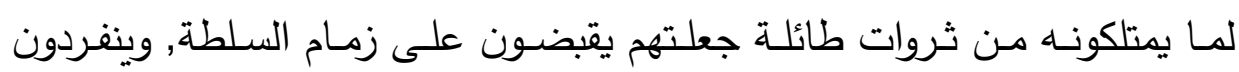


بصنع القرار السياسي, أما أغلبية المواطنين فنجدهم فقراء معدومين كبلتهم الديون وحولتهم إلى عبيد لهؤلاء النبلاء الذين يحق لهم التصـرف معهم كمـا يشـاءون فيجعلونهم عبيدًا لهم أو يبيعونهم إلى الأجانب فيتحول بذلك الأحرار إلى أرقاء مستعبدين, وعلى الرغم من ذلك كله لـ يتم الاستسـلام إلى هذه الأوضـاع السيئة, فقد حولوا المعاناة والمظالم التي تعرضوا لها إلى إرادة وعزيمة حقيقية استطاعوا من خلالها أن يخرجوا من الظلام إلى النور , فطالبوا بحقوقهم وتمكنوا بأيديهح من تغير مجتمعهم, وقد ساعدهم في ذلك قادة مخلصون آمنوا بقضيتهم ودافعوا عنها فاسـتطاعوا بفضـل اصـرارهم أن يرســوا معـالم المجتمـع الـديمقراطي الـذي يعيد للمواطن حريته وكرامته واستقلاليته فيصبح بذلك صاحب السلطة السياسية وصانع القـرار السياسـي, فتشـكل بـذلك المجتمـع المـدني الــي خـرج مـن رحم المعانـاة والمظالم,وتمكن من أن يرسم صورة حية أبدعها المواطن, وسجل بحروف من نور قصه حية عبرت أصدق تعبير عن صورة واقعية لمجتمع مدني لم يعد لله وجود في أيامنا هذه وعلي الرغم من ذلك فإنه ليس مستحيلا إذا أردنا ذلك فحولنا هذه الإرادة إلى ممارسة فعلية حقيقية 73. ومن الأمور التي أدت إلى نجاح المجتمع المدني أن قادة هذا المجتمع لم يكن هدفهم هو السعي وراء السلطة دن أجل السلطة والانفراد بالقرار , وإنما كانت السلطة بالنسبة لهم مجرد وسيلة للوقوف بجوار هؤلاء الجماهير ومساعدتهم على استعادة حقوقهم الضائعة, فقد جاءوا إلى السلطة لتحقيق مصالح هؤلاء الجماهير لم يكن لهم أي مطامع أو رغبات شخصية يرغبون في تحقيقها من خلال توليهم للسلطة فتحقق لهم مـا أرادوا. ومن الأسس التي تؤدي أيضـا إلى نجاح المجتمع المدني الاستمرارية وتضـافر الجهود, فقد كان هنـاك اهتمام بفتح أسواق جديدة وإقامة أسطول بحري, فقد أخذوا على عاتقهم الاهتمام بتحسين أحوال المزارعين, 
والحرفيين والصناع, والتجار , وكل ذلك راجع إلى القائد صولون, وكل من جاءوا

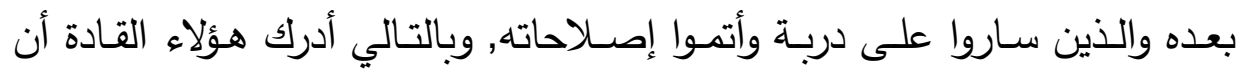
الديمقراطية الحقيقية والمجتمع المدني المنشود ليس مسؤولية فرد بعينة, وإنما هو إنهاه

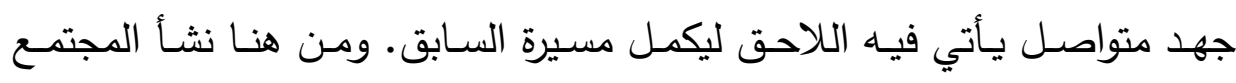
المدني بفضل تفاعل الهيكل المؤسسي الذي يجسده المسؤولون والجسد السياسي لئي

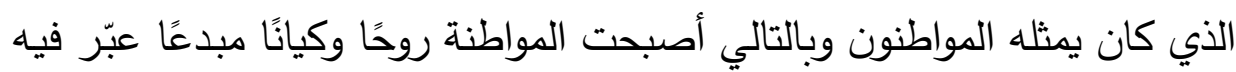
المواطن عن ذاته أصدق تعبير ولم يكن بها إنكار للذات بأي حال من الأحوال

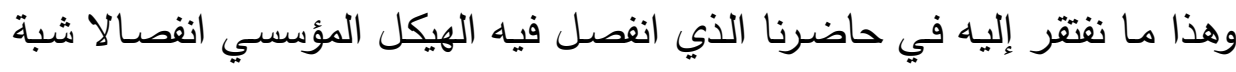
كامل عن الجسد السياسي الذي يمثله المواطنون الذين أصبح شعارهم إنكار الذات

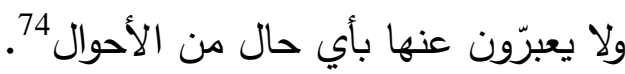

ومن الأمور التي أدت إلى نجاح المجتمع الددني هذا التوازن الرائع الذي

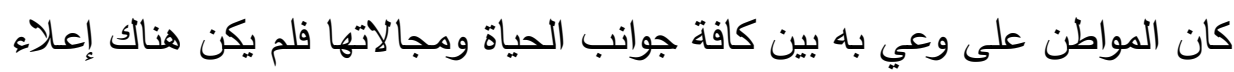

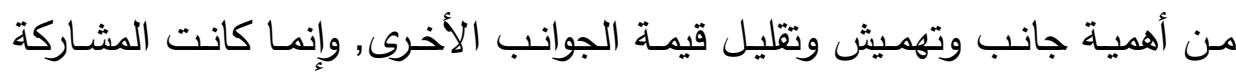
المدنية تعني المشاركة والتفاعل في كل المجالات الدينية, والاجتماعية, والسياسية,

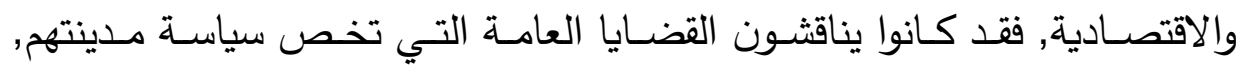

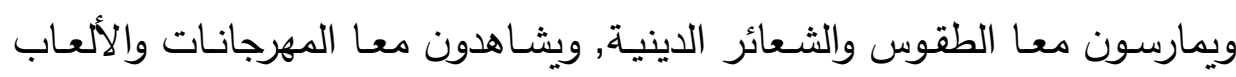
والمسابقات, ويشاركون فيها ويحافظون على الروابط الاجتماعية, ويتعاونون من

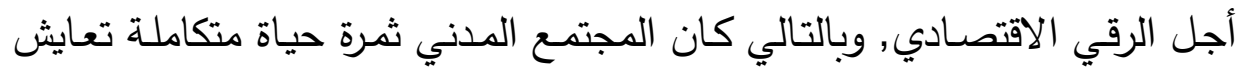

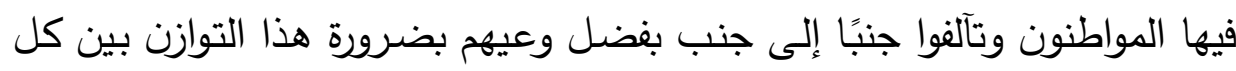

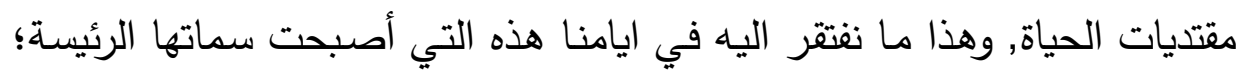
العزلة والاغتراب وفقدان التوازن 
كذلك يؤكد موري بوكتشين أن الفن هو أحد الركائز الأساسية التي يقوم عليها وجود المجتمع المدني وتدعيمهـ استتادا أيضـا إلى الدور الذي قام بـه الفن في إرساء دعائم المجتمع المدني اليوناني, فقد كان للفن دورًا رئيسًافي إرساء قيم الديمقراطية والمجتمع من خـلال الأشعار والمسرحيات والروايات التي كان يتجمع الآلاف لمشـاهدتها, وكان لها في نفوسـهم أبلـغ التأثير فساهمت بشكل فعـال في إرساء الثقافة الديمقراطية وقيم المجتمع المدني وتدعيمها, وهو ما نفتقر إليه في ايامنـا هذه أيضـا. لقد بينت الأعمـال الدراميـة كيف تحول المجتمع من الأعراف والعـادات الخاطئـة التـي تثـجع على القسـوة والعنـف إلـى مجتمـع يسـوده السـلام والاستقرار والتعاون بين كل أفراده, وبذلك أوضحت هذه الثقافة التي عبر فيها الفن أصـدق تعبيـر كيـف يمكن أن يـتم اسـتبدال لغــة العنـف بالعقلانيـة, والأعـراف والعادات الخاطئة التي تشجع على الهيمنة والطبقية بقيم الحريـة والالتزام بأحكام القانون التي يجب أن يخضع لها الجميع حكام ومحكومين على السواء ${ }^{76}$ وإلى جانب الحريـة والعقلانيـة بوصفهما الركيزتين الأساسيتين اللتين يقوم عليهمـا المجتمـع المـني هنـاك ركيزة ثالثة, وهي أن يكون هذا المجتمـع المدني تجمعًا أخلاقيًا يهدف إلى تحقيق العدالة بين كافة مواطنيه, ومن هنا فإن العدالة وليس التقليد, والعقل وليس العرف هما أساس أي مجتمع مدني أخلاقي, فدونهما لا يمكن أن تكتسب الديمقراطية ولا المجتمع المدني أي تبرير أخلاقي. ومن هنا فإن وجود المجتمع المدني يتطلب وجود أكبر قدر من العقل والحكمة من أجل ديمقراطية حقيقية يتحقق فيها حريـة المواطن بشكل فعلي, لأن الحريـة والعقلانية وجهان لعملة واحدة, حيث إن في ظل الصـراعات التي لا تعرف إلا لغـة البقاء للأقوى لا يمكن أن يكون هنا كأي وجود لحريـة المواطن, وفي المقابل فإن غياب الصـراعات سيؤدي إلى تنفس هواء الحريـة مـن خـلال سيادة لغـة العقلانيـة التي 


\section{مجلة وادي النيل للاراسات والبحوث الإنسانية والاجتماعية ـ مجلة علمية محكمة}

(ISSN : 2536 - 9555)

ستؤدي إلى مساواة حقيقية بين الجميع,وبالتالي مشاركة فعالة في مجتمع مدني حقيقي

وهنا يعترض موري بوكتشين على الادعاءات الحديثة التي رأت أن المواطنة

الآثينية لم يكن بها وجود للفردية لأنها كانت لا تعترف إلا بروح الجماعة, وبالتالي اختفـت الاستقلالية والحريـة الفرديـة, فقد أكد على زيـف هذه الادعـاءات ؛لأن الفردية الحديثة التي يتم التفاخر بها ماهي إلا مزيج من العزلة والاغتراب وترجيح المصـالح الأنانيـة, والتي ترتب عليهـا طمس دور المـواطن وتغيبـه عن المشـهـ السياسي وتخليه عن اتخاذ القرار في مجتمعـه, وذلك على العكس من المواطن الآثيني الذي أدرك أن الإنسـان كائن اجتمـاعي وسياسـي بطبيعته, وبالتالي فإن فرديته واستقلاليته لا تتعارض مع تحقيق الصالح العام الذي سيكون أصدق تعبير عـن هـذه الفرديـة وتلك الاسـتقلالية. كـلك يـرفض بوكتشـين الـزعم القائسل بـأن الديمقراطية الآثينية والمجتمع المدني الناشئ عنها كان نتيجة عادات وتقاليد عفوية تلقائية, وبالتالي تصبح الديمقراطية ظاهرة تقوم على مجرد العادة والاتفاق وهذا الزعم يعني تجاهل كل الإصـلاحات والمجهودات التي قام بها الآثينيون من أجل إقامة مجتمع مدني وترسيخه. ويتجاهل هذا الزعم أيضا الاعتراف بأن الديمقراطية هي بنيـة متقنـة ونتـاج جهود هادفـة ومدروســة لتحقيق أهداف وإنجـازات مدركـة بوضـوح وعمق ,ومعني ذلك أن المجتمـع المـدني الاثيني قـ نشـأ بفضـل جهـود مقصودة واعية وإرادة حقيقية أخذت على عاتقها مهمة إرساء دعائم هذا المجتمع من خلال تعاون مواطنيه وتكاتفه من أجل تحقيق هذا الغرض, وليس من خلال المصادفة والتلقائية كما يزعم البعض 78.

كذلك يؤكد موري بوكتشين أن المدنية اليونانية لم تكن المثال الوحيد لوجود مجتمع مدني, فقد كانت هنالك بعض المحاولات لإرساء دعائم مجتمع مدني قائم 
على مواطنة حقيقية في بعض فترات العصور الوسطى في الددن الإيطالية وفي

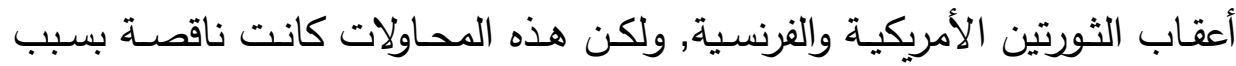
النزعات القومية التي حولت الاهتمام من التركيز على دور المواطن إلى سلطة الدولة المركزية, وبالتالي عجزت هذه المحاولات عن تحقيق ما تصبو إليه ${ }^{79}$ وهنا يؤكد موري بوكتثين أن حب المدينة هوإحساس عميق وثابت بالولاء لرفاهيتها، ومحاولة لوضـع هذه المشاعر في سياق ثقافي وبيئي غني, وهو مـا يميز بوضوح غالبية مدن العصور الماضية, وهو ما نفتقر إليه في أيامنا هذه هذهئ. إن استعادة الشعور بالمؤسسات المدنية القائعة على المشاركة والتي كانت تميز حياة المدينـة والمواطنـة في يوم من الأيـام, هي استعادة تلك المثل العليا للحياة المدنية والحساسية المدنية التي يمكن أن تتقذنا من الدمار الهائل الذي في هوني يسببه التحضر الزائف والدولة المركزية على الددينة والريف على حد سواء ${ }^{81}$

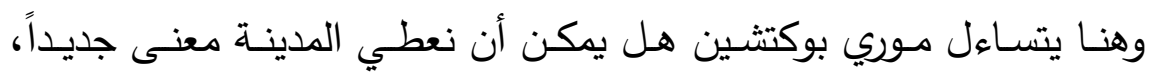

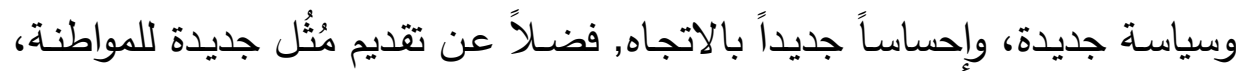
والتي كان كثير منها في الواقع قد تم تحقيقه في أوقات سابقة؟ نحن نتجاهل

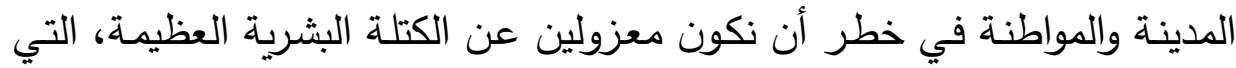

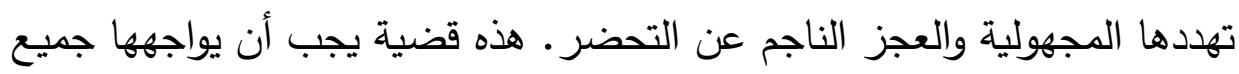
الأشخاص المتمين اجتماعياً وبيئياً, ويجب أن يتم الاهتمام بمسألة مستقبل المدن لهن لهن

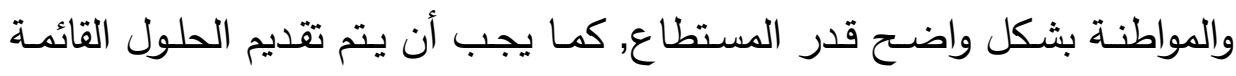

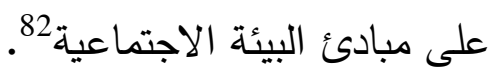
يجب أن تعود المدينة إلى مكانها الصحيح فالمدينة ليست فقط "الاستثمار" الاجتماعي الأول للفرد, ولكنها البيئة الاجتماعية الأكثر حميمية, وبسبب أهميتها

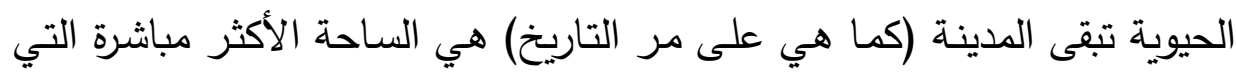


يمكن للفرد أن يعمـل فيهـا بوصـفه كائنًا اجتماعيًا حقيقيًا, ويمكنـه مـن خلالهـا الوصـول إلى الحلول الاجتماعيـة الأكثر إلحاحًا للمشـاكل الأوسـع التي يواجها. وبقدر ما يكون تعريف الفرد الذاتي بوصفه شخصًا يتمتع بالتمكين والمواطنة أمرًا ممكنًا اليوم، يجب استعادة التضـاريس المدنية على جميع مستوياتها من خلال مكوناتها وإعادة تشكيلها بطرق جديدة لجعل الأشخاص عمليين بشكل جاد. وهكذا فإن إعـادة المواطنـة المدنيـة للمواطن تصسبح قضـية شخصية إضـافة إلى قضية اجتماعية

ومـن هنـا فإنـه يجب استعادة الأشـال والقيم المدنيـة التي تعزز مواطنـة

نشطة, ولكي يحدث ذلك فإننا يجب أن نستعيد السياسة بوصفها مشاركة تفاعلية قائمة على ديمقراطية حقيقية, وبالتالي العودة إلى المدينة بوصفها اتحادًا أخلاقيًا،

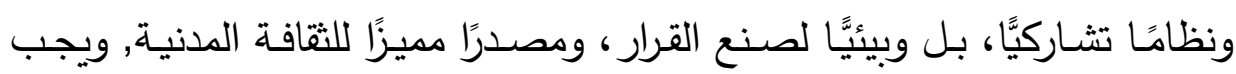
إعـادة المفهوم المـني للمجتمـع مـرة أخرى إلى تـاريخ الأفكار البشـرية والحكمـة العمليـة, كمـا يجـب إعـادة التفكيـر فيـهـ بشـكل نقدي بوصـفـه فكـرة مـن الأفكـار والأنشطة التي تؤدي إلى السمو كما حدث في فترات مختلفة من التاريخ 84.

\section{3- المتهمع البيئي التمرري}

وهنا نأتي إلى التساؤل الحاسم مـا الذي يقصده موري بوكتشين بالمجتمع البيئي التحرري؟ وما الأسس التي سيقوم عليها؟ وما البرنامج الشامل الذي يمكن التعويـل عليـهـ لتحقيقـه على أرض الواقـع؟ ويجيـب مـوري بوكتشـين عـن هـذهـ

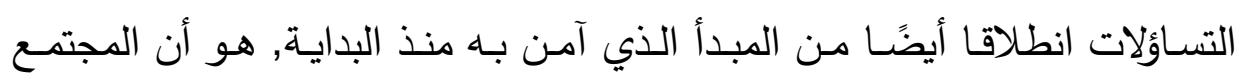
البيئي التحرري هو المجتمـع الذي سيتحقق فيه التوازن,والتفاعل, والتكامل بين البيئة الطبيعية والبيئة الإنسانية, ثم ينتقل هذا التوازن إلى داخل المجتمع ذاته من 
خلال تكاتف جهود كافة أفراده لتحقيق هذا التوازن على كل المستويات السياسية, والاجتماعيـة, والاقتصـادية, والبيئيسة, والإنسـانية وهـي الملامـح الأساسـية التي ستثكل هذا المجتمع. وإذا تساءلنا عن طبيعة هذا المجتمع الذي سيتحقق فيه هذا التكامل على كل المستويات نجد أنه في رأيه المجتمع الكونفدرالي اللامركزي؛ لأنه المجتمع الوحيد الذي يمكن أن تتحقق في ظله الديمقراطية الحقيقية المباشرة التي يكون فيها للمواطن دور حقيقي في صنع سياسـة مجتمعـه من خـلال مؤسسـات تحرريـة, وسـوف يتحقق في ظلــه الازدهـار الاقتصـادي الـذي يـوفر للمواطنين الاحتياجـات الضـرورية الحقيقية التي سيسعى جميع المـواطنين إلى تحقيقها,ولا تكون مقصورة على فئة بعينها, وهو المجتمع أيضا الذي ستحقق في ظله الروابط الاجتماعيـة, وتترسـخ العلاقات الإنسـانية بأسـى معانيها, وبالتالي سيكون قادرًا علي تشكيل مصفوفة من العلاقات السياسية, والاجتماعية, والاقتصادية, والبيئية, والإنسانية التي يكون كل منها جزء امن الآخر من أجل مجتمع بيئي تحرري. وإذا تسـاءلنا عن الشكل السياسي الملائم للمجتمع البيئي التحرري نجد أنـه يكمن في الديمقراطية المباشرة التي يكون أساسها التجمعات الشعبية, والذي يكون معارضًا لجميع أشكال السيطرة التي تعوق وجود الحرية وهنا يؤكد موري بوكتشين أننا لا ينبغي أن نخلط بين الكونفدرالية القائمـة علي السلطة الشعبية وبين الفيدرالية التي هي ببساطة استمرار للدول المركزية في شبكة من الاتفاقات التي تحافظ على صـلاحيات صنع السياسـة دون تدخل يذكر من جانب أي مواطن. فالفدرالية هي ببسـاطة الدولـة التي تكتفي بسلطة الدولـة المركزيـة، كمـا هو الحال في الولايات المتحدة الفيدرالية، والاتحـادات الأوروبية، ورابطة الدول المستقلة، ومجموعات الدول الكبرى القاريـة الضخمة التي تعتمد في الأساس على إزالة أي سيطرة للناس على الدول المركزية.86. 
وهنا يري موري بوكتشين أنه لكي يكون لهذه المجتمعات الكونفدرالية وجود حقيقي يجب أن نحاول خلق ثقافة سياسية جديدة تشمل جهودًا حقيقية لتحقيق هذه الأهداف، مـع إدرالك كامل لكل الصـوبات التي تواجهنا والتي يجبأن نتخطاهـا بإرادة وإصـرار حقيقي. ويجب أن تبدأ هذه الثقافـة السياسية من الحي, "فالحي" ليس مجرد المكان الذي يبني فيه الناس بيوتهم, ويربون أطفالهم, ويبتاعون الكثير من بضائعهم إنه يشمل المناطق الحيويـة التي يتجمع فيها الناس لمناقثـة القضـايا السياسية والاجتماعية. وبالفعل فإن مدى مناقثـة القضـايا العامة بشكل علني في مدينة أو بلدة هي التي تحدد حقاً الحي بوصفه مساحة مهمة للسلطة السياسية. إن الحي هو مركز المدينة حيث يمكن أن يجتمع المواطنون لتبادل وجهات نظرهم وإعطاء تعبير علني لسياساتهم, وقد حدث ذلك بالفعل في الكونفيدراليات اليونانية, وفي المدن الإيطالية في العصور الوسطى, وفي التجمعات الباريسية التي أعقبت الثورة الفرنسية

ولكي يكون لهذه المجتمعـات التحرريـة وجود حقيقي يجب أن نعتمـد في

الأساس على الإمكانات الحقيقية للبشر , كما نعرفها من الماضي والحاضر ، يجب أن نكون على وعي بأن المجتمع اللاعقلاني الحالي ليس الفعلي- أو الحقيقيالــي يسـتحق أن يوصـف بأنـهـ إنسـاني؛ فهـو يتــاقض مـع تحقيـق الإمكانـات الإنسانية للحرية والوعي الذاتي، ومن ثم فهو غير واقعي بمعنى أنه خيانة لأعظم الصفات الإنسانية وهي القدرة على التعقل والابتكار 88.

تمثل المجتمعات التحررية مشروعًا جديًا - بل تاريخيَّا حقَّا- ليجعل السياسـة أخلاقيـة في طبيعتها وقواعد تتظيمها. وهي تسعى إلى استعادة المجـال العـام لممارسـة المواطنـة الحقيقيـة في الوقت الذي تتفصـل فيـه عن الدائرة البرلمانيـة الكئيبـة وتحريفهـا لآليـة "الحزب" بوصـفها وسـيلة للتمثيـل العـام. وبـذلك لا تعـــ 
المجتمعـات التحرريـة مجرد "استراتيجية سياسية"؛ ذلكأنها محاولـة للعمـل مـن

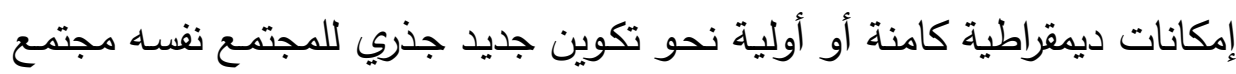
بيئي تحرري موجه نحو تلبية الاحتياجات البشرية، والاستجابة للضرورات البيئية،

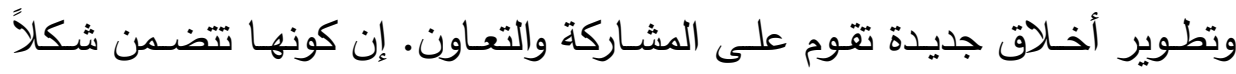
حقيقياً من السياسة هو حقيقة بديهية. والأهم من ذلك أنها تتطوي على إعلى إنادة

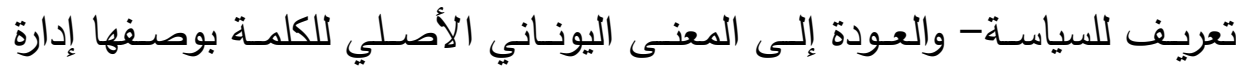

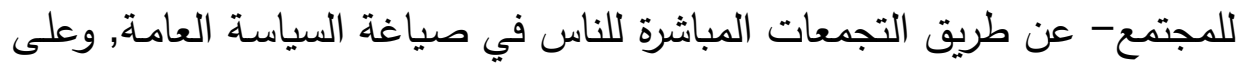

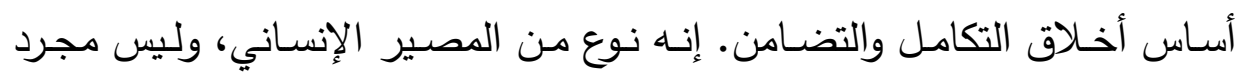

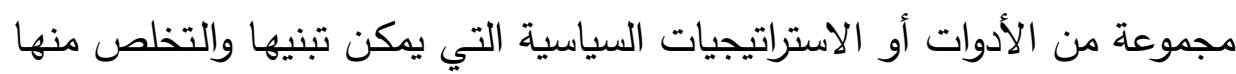
بهدف تحقيق السلطة 89.

من الواضح أن التغييرات المؤسسية لا تحدث في فراغ اجتماعي, كما أنها لا

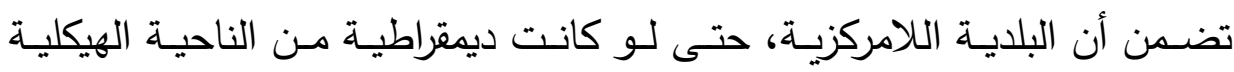

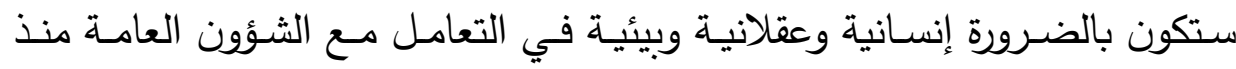
البداية إن المجتمعات التحرية تقوم على الكفاح من أجل تحقيق مجتمع عقلاني

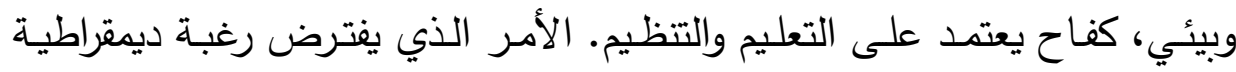

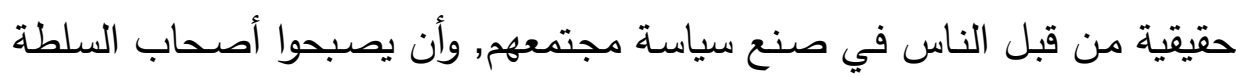

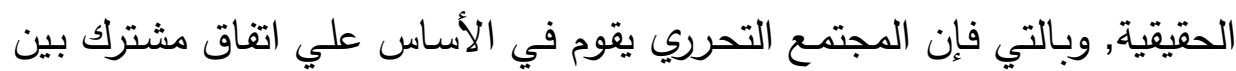

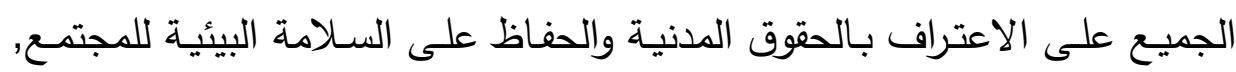
وبالتالي فإنه يهدف في الأساس إلى حماية حقوق الإنسان وتدعيم واجباته البيئية المميزة

تثكل المجتمعات التحررية سياسة البيئة الاجتماعية، وهي جهد ثوري يتم

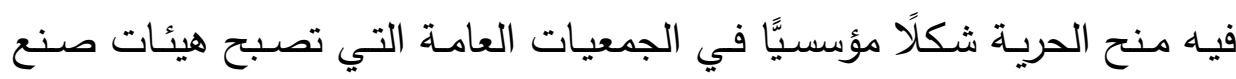




\section{مجلة وادي النيل للاراسات والبحوث الإنسانية والاجتماعية ـ مجلة علمية محكمة}

(ISSN : 2536 - 9555)

القرار , حيث يمكن إنشاء تجمعات شعبية تجلب الناس للمشاركة الكاملة والمباشرة في الحياة السياسية؛ إذ إن المجتمع التحرري هو في المقام الأول سياسـة تسعى إلى خلق مجال عام ديمقراطي حيوي, حيث يعتمد في الاساس على ثقافة سياسية حقيقية تسعى إلى إعادة تأهيل الفرد وشحذ حساسيته بوصفه مواطنًا حيَّا 91. وهنـا يؤكد موري بوكتشين أن المجتمع التحرري الذي ينشده ليس مجتمعًا فوضويًا بأي حال من الأحوال؛ لأن هذه الاتجاهات الفوضوية تدعو إلى القضـاء على السـطة بشـكل كامـل وهذهـ- في رايـه- أفكـار منافيـة للعقـل والواقع مثل المطالبـة بإلغـاء الجاذبيـة الأرضـية فـالمجتمع التحرري يعترف بالسلطة, وكل مـا يسعياليه هو أن تنتقل هذه السلطة من القـة الى القاع بحيث يصبح المواطنون هم أصحابها الحقيقيون لكي يتمكنوا من خلال تكاتف جهودهم القائمة على الحوار والتعليم والتنظيم- وليس علي الفوضى - منبناء مجتمع بيئي إنساني تحرري 92. تهـدف المجتمعـات التحرريــة أو الكونفدراليـة إلـى توسـيع المؤسســات الديمقراطية من خلال فتحها أمام أوسع مشاركة عامة ممكنة في أي وقت. ومن هنا فإن تعميق الديمقراطية!" لا يكون من خلال القضاء على سلطة الدولة، ومن ثم التخلي عنها مطلقا, وإنما يكون من خلال توسيع السلطة الشعبية حتى تصبح كل القوى تابعة لمؤسسات ديمقراطية تثاركية 93. وهنا يؤكد موري بوكتشين أن سياسة المجتمع التحرري لن يكون لها وجود حقيقي إلا مـن خـلال الاتصـال الشخصسي المباشـر , ونطاقـه المرجو توسيعه مـن خلال محاولة الوصول إلى كل مكان في منطقة أو أمسة. هذا النوع من الاتصال المباشر هو الذي يؤدي إلى الثقة والتفاعل الشخصي والتعليم وجهًا لوجه, ويشجع على تطوير الديمقراطية وجها لوجها, لذا فإن نقطة البداية الحقيقية هي مجموعة 
الدراســة الصـيرة، وقاعـة المحاضـرات المحليـة، وصـــافة الأحيـاء، والخطــاب الشخصي

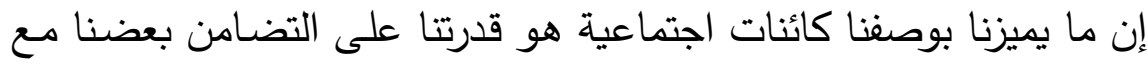

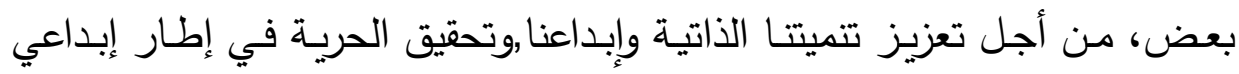
اجتماعي ومؤسسي. "أن المواطنة المنعزلة عن المجتمع تكون إذلالًا لذاتتا بوصفنا

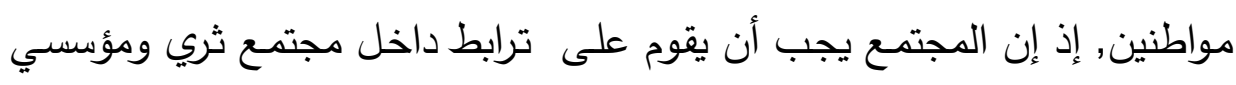

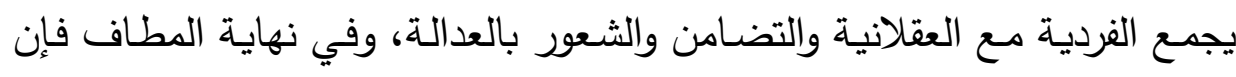

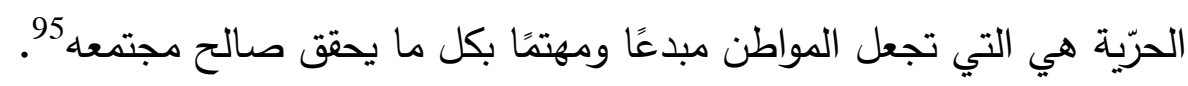
إن السياسة الحقيقية تقوم على الثعور بالالتزام تجاه مجتمع بشري يسترشد

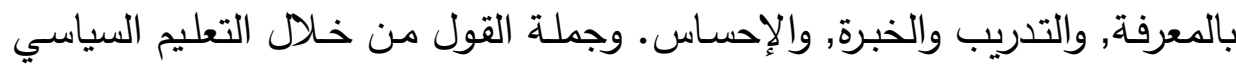
الذي يتم إنشاؤه في سياق المشاركة السياسية، وليس من خلال الطاعة المؤسسية.

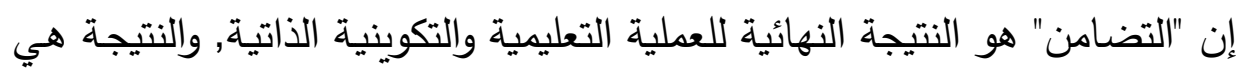
أن الوعي هو الذي سيحدد في النهاية ما إذا كانت البشرية ستحقق شعورًا غنيًا بالجماعة دون التضحية بشعور غني بالفردية. إن السياسة الإبداعية دون مواطنين

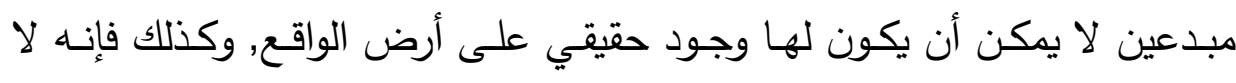

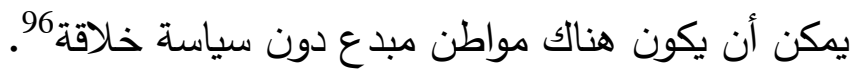

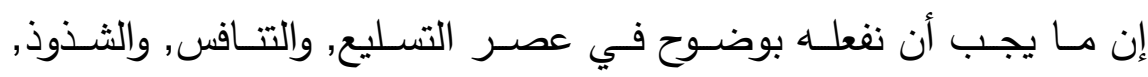

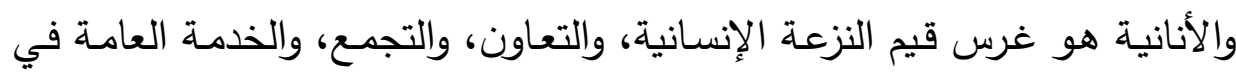
الممارسة اليومية للحياة المدنية، ليس في مدارسنا، ومؤسساتتا الدينية، ومجتمعاتتا لئها

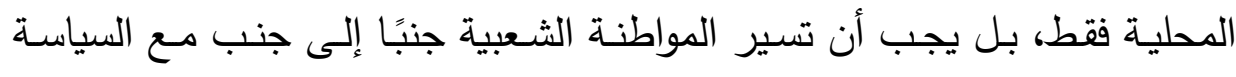

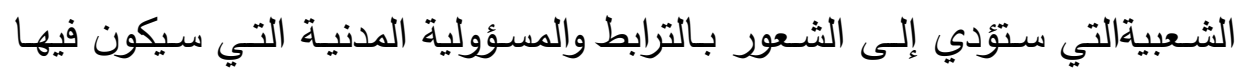
المواطنون مشاركين بنشاط في صنع مجتمعهم البيئي التحرري 
كذلك يجـب أن يصـبح تطوير المواطنـة فنًا ولـيس مجـرد تعليم, فهو فن إبداعي بـالمعنى الأخلاقي الذي يستجيب للرغبـة الإنسـانية العميقـة للتعبير عن الذات في مجتمع ثري ذي معنى, وكذلك يجب أن يكون فنًا شخصيًا يدرك فيه كل مـواطن تماءًا حقيقـة أن مجتمعـهـ يعهـد بمصسيره إلى صـدقه الأخلاقي, وولائهـ, وعقلانيتهـه ومـن ثم يفترض المفهوم التحـرري للمواطنـة أن كل مـواطن مؤهـلُ للمشاركة مباشرة في "شؤون الدولة"، وأن الأمـر الأكثر أهميـة هو تثـيعه على القيام بذلك؛ لذا يجب أن يتم توفير كل الوسائل سواء كانت أخلاقية أو مؤسسية لتعزيـز المشـاركة بالكامـل لنراهـا عمليـة تربويـة وأخلاقيـة تحـول الكفـاءة الخاملــة للمواطن إلى واقع فعلي, كمـا يجب أن يتم تتظيم الحياة الاجتماعيـة والسياسية بوعي من أجل تعزيز حساسية عميقة، أوشعور حقيقي بالرعاية والتعاون المتبادل

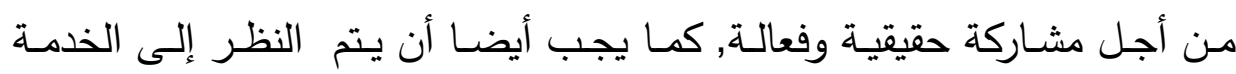
العامة على أنها سمة إنسانية فريدة، وليست "منحة" يمنحها المواطن للمجتمع أو مهمة شاقة يجب عليه الوفاء بها 98. وبدلا من الاعتماد على ممثلين عن الشعب تقترح السياسة التحرريـة وجود مندوبين لا تكون مهمتهم أن يكونوا مفوضين عن الثعب بأي حال من الأحوال وإنمـا تتحصـر مهمتهم في تتظيم جدول الأعمـال في اجتمـاع المدينـة, وتسـيل

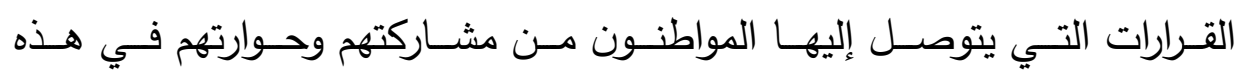
الاجتماعات. ومن ثم فإن مهمتهم تقتصر على الإشراف والتتظيم, والاعداد فقط لهذه الاجتماعـات, وبذلك يكون اتخاذ القرار مسؤولية المواطنين أنفسهم وليست مسؤولية هؤلاء المندوبين 99. 
ومن ثم يمكن للناس أن يعيدوا تشكيل أنفسهم من الأحاديات المنعزلة إلى كيان سياسي مبدع, وخلق حياة حيوية ووجوديّة، بل في الواقع بروتوبلازميّة مدنيّة لها شكل مؤسسي إضافة إلى محتوى مدني 100. ويتطلب ذلك أن يكون لديهم فرصـة حقيقية في المشاركة في صنع القرار . وسوف يتحقق ذلك من خلال خلق ديمقراطية مباشرة خالية من التحيزات الجنسية والعرقية والهرمية. ويقدم لنا التاريخ عددًا من الأمثلة العملية للنماذج التحريريـة إلى حد كبير كما يزودنا بأمثلة عن الاتحادات التحرريـة والدوائر التي جعلت تنسيق مجتمعات الحكم الذاتي ممكنًا دون المساس باستقلالهم وحريتهم 101. وسوف يتطلب ذلك أيضـا وجود ثقافـة جديدة، وليس مجرد حركـة أخرى تحاول إزالة أعراض أزماتتا دون التأثير على مصادرها. يجب علينا أيضا التخلص من السلبية والانهزام الذاتي الذي هيمن على نفوسنا، وليس فقط إزالة المؤسسات التي تجسد الهيمنة الاجتماعية. لكن يجب عدم التضحية بالحاجة إلى ثقافة جديدة ومؤسسـات جديـدة دون أن نعتمـد علي فكرة ضـبابية عـن الخـلاص الثخصسي, والذي يجعلنا قديسين ومنعزلين, فنتحول في نهاية المطاف إلى جماهير غير قابلة للإصـلاح. إن التغيرات في الثقافة والثخصية تسير جنبًا إلى جنب مـع جهودنـا الراميـة إلى تحقيق مجتمـع بيئي تحرري, مجتمـع قـائم على التوازن, والتكامـل, والتفاعل بين كافة أعضائه التئ. وهنا يتفق موري بوكتثين مع جون لوك الذي أكد أن الناس قد خلقوا أحرارًا ومتساوين ومستقلين, وبالتالي لا يمكن إخضاع هؤلاء لأى سلطة سياسية دون رضاهم. وهو الرضا الذى يتفقون عليه جميعًا فيتحدون معًافي كيان واحد من أجل سلامتهم وراحتهم, وحتى يسود الوئام فيما بينهم ويتبادلون المنافع. كذلك فإن

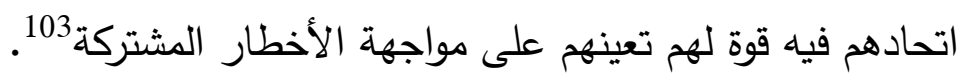


ويتقق أيضا مع روسو الذي أكد أن الإرادة العامة وحدها هي التي بمقدوها أن توجه قوة الدولة نحو تحقيق الخير العام وتحقيق المصالح المشتركة التي سيتفق عليها الجميع. وإذا كانت الدولة لا تقوم إلا على اتحاد أعضائها, فإنها لن تحقق صالح أعضائها, إلا عندما يشكل هؤلاء الأفراد قوة عامة قادرة على تحقيق ما تطمح إليه4104.

ويتقق أيضا مع كانط الذي أكد أنه يجب أن يرتبط الناس بعضهم مع بعض مكونين إرادة جماعية, وبذلك يثعر الفرد بأنه صاحب السيادة وأنه لا يطيع إلا نفسه, ومن ثم يصبح المواطنون جميعًاصاحبي السيادة في الدولة. 105 ويتفق كذلك مع إدموند بيرك (Edmund Burke) (1729 - 1797) الذي أكد أن الثعب يجب أن يصبح هو المشرع الحقيقي الوحيد, وذلك لأن الثعب هو الذى يصنع عاداته وتقاليده, وبالتالي فإنه صاحب السيادة في

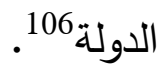
ويتقق أيضا مع توماس بين (Thomas Paine) (1737 - 1809) الذي أكد أن السيادة لا تتسب إلا إلى الأمة ولا تتسب إلى أي فرد, ومن ثم فالسيادة الوحيدة هي السيادة الثعبية, وبذلك يحكم الناس أنفسهم ويحققون أهدافهم ومصالحهم 107.

ويتقق كذلك مع إريك فروم الذي أكد أنه لابد من وجود ديمقراطية إيجابية نشطة (ديمقراطية مشاركة)؛ حيث شئون المجتمع قريبة إلى قلوب المواطنين, وتهمهم بالقدر نفسه الذي تهمهم شؤونهم الشخصية, وبالمشاركة في حياة الجماعة وشؤونها, ومن ثم يصبح الأفراد أكثر إقبالاً وحماسًا في حياتهم الشخصية ل108. ويتقق أيضا مع روبرت دال (Robert Dahl) ( 1915 - 2014 ) الذي أكد أنه من خلال إشراك أفراد الثعب في عملية حكم ذاتهم, فإنهم جميعًا يتعلمون 
كيفية التصرف بوصفهم أفرادًا مسئولين أخلاقياً. وهذه المسئولية المشتركة تمكنهم من صنع قرارات تتعلق بمبادئهم, وقواعدهم, وقوانينهم, وسياساتهم, ونهجهم العام, وكل ما يتعلق بأمور حياتهم 109. ويتفق مـع جون رولز ( John Rawls ) (1921-2002) الذي أكد أن القوة الديمقراطية السياسية هي قوة العامـة المتمثلة في كل أفراد المجتمع بوصفهم مـواطنين أحرار ومتساوين بوصفهم هيكلاً جمعيَّا110. ومن ثم فإن فكرة الحكم الذاتي الديمقراطي تعني: أن المـواطنين يجب أن يعملوا معًا بشكل إرادي لإدارة شُون مجتمعهم السياسية بشكل جماعي 111. ويتفق مع آلان تورين الذي أكد أن الهدف الرئيس من الديمقراطية هو إنشاء مجتمـع سياسـي عـادل يـتم فيـه إلغـاء كافـة أشكال السيطرة والاستغلال بالسـماح للأفراد, والجماعات بأن يصبحوا أفراد أحرارًا,منتجين لتاريخهم 112. ويتفق كذلك مع رونالد دوركين (Ronald dworkin) (1931- 2013) الذي أكد أننـا إذا أردنـا المسئولية, فـإن كـل شـخص يجـب أن يـتم السـماح لـه بالمشاركة بطريقة صحيحة في القرارات الجماعية التي يتم حكمه من خلالها وطبقًا للتصور الخاص بديمقراطية المشاركة, فإن الأفراد يحكمون أنفسهم لأن كلاً منهم يكون شريكًا تامًا في المشروع السياسي الجماعي 114. وطبقًا لتصور المشاركة, فإن الحكم بواسطة الثعب يعني الحكم من خلال كل أفراد الشعب, فإنهم يعملون معًا بوصفهم متكاملين ومتشاركين متساويين في هدف جماعي, هو الحكم الذاتي 115. إذا كان هذا هو ما يتعلق بالثكل السياسي للمجتمع البيئي التحرري, فماذا عن الشكل الاقتصـادي الخاص بهذا المجتمع؟ يجيب موري بوكتشين عن هذا التسـاؤل مؤكدًا أن مـا ينطبق على السياسـة ينطبق أيضـا على الاقتصــاد, إنـه 
الاقتصاد الذي يجب أن يتم التخلص فيه من استغلال الاقتصاد الرأسمالي الذي

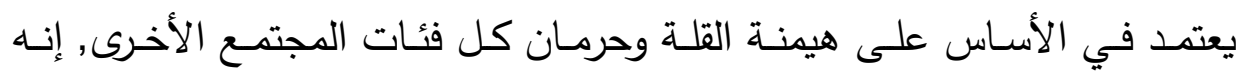

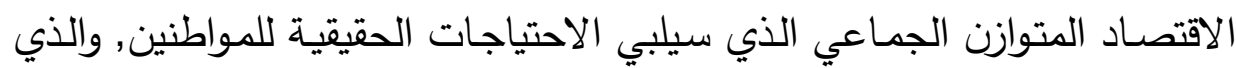

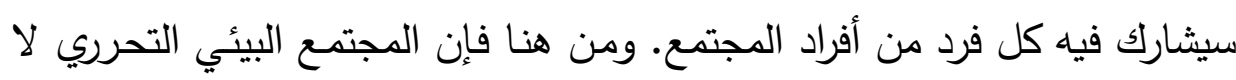

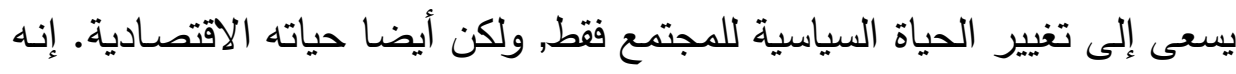

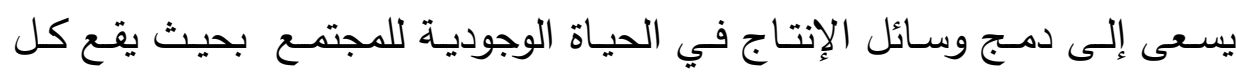

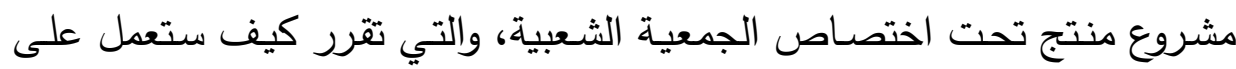
تلبية مصالح المجتمع ككل. يجب التغلب على الفصل بين الحياة والعمل، السائد في الاقتصاد الرأسمالي الحديث. ويجب أن يلبي هذا الاقتصاد رغبات المواطنين

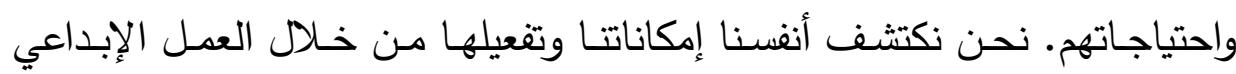
والمفيد الذي سيحقق التوازن والتكامل بين البيئتين الطبيعية والإنسانية 116. وعلي الرغم من أنه اقتصادٌ اشتراكي فإنه يختلف عن ذلك الاقتصاد الذي دعاإليه كارل ماركس؛ فإذا كان العامل الاقتصادي عند كارل ماركس هو العامل

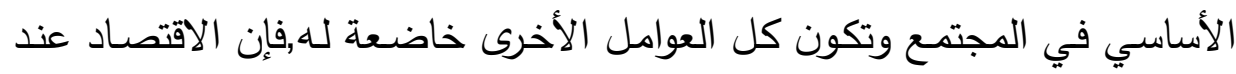

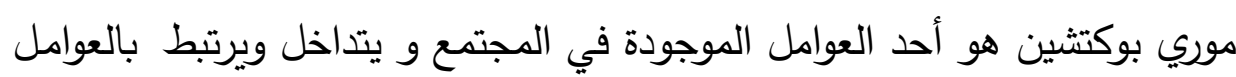

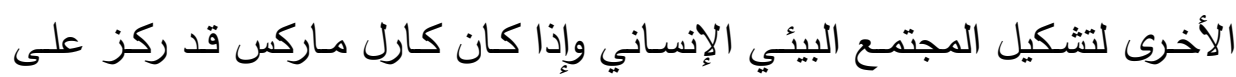

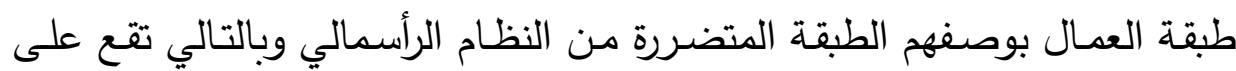

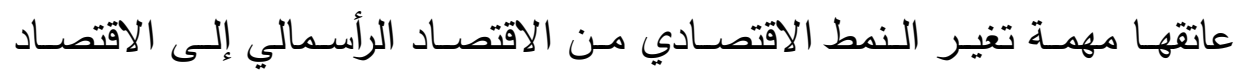

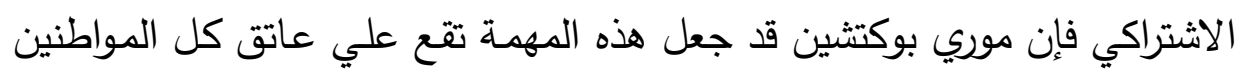

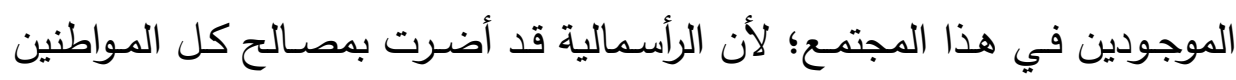

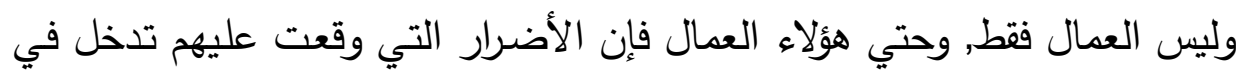
إطار كونهم مواطنين وجزءًا لا يتجزأ من هذا المجتمع. 
إن العهـال هـم في الأسـاس كائنـات حيـة: آبـاء وأمهـات، وأبنـاء وبنـات، وأشخاص لديهم أحلام ورؤى، وأعضاء في المجتمعات, وليس فقط نقابات العمال.

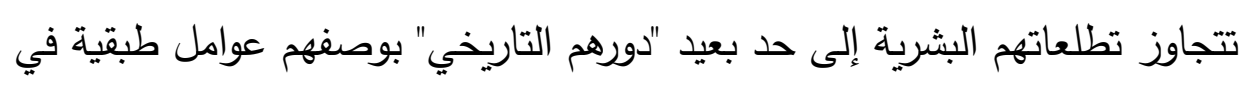

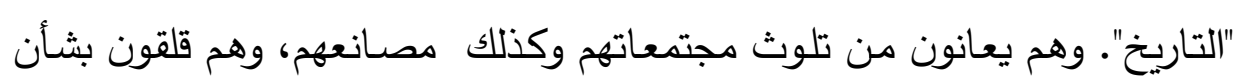
رفاهية أبنائهم، ورفاقهم، وجيرانهم، ومجتمعاتهم بنفس قدر اهتمـامهم بوظـائفهم

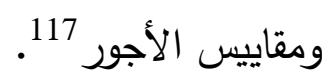

ومـن هنـا يجب أن يأخـذ عمـال المهـن المختلفة مقاعدهم في التجمعات

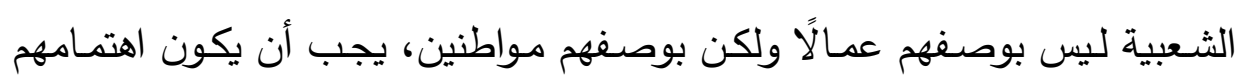

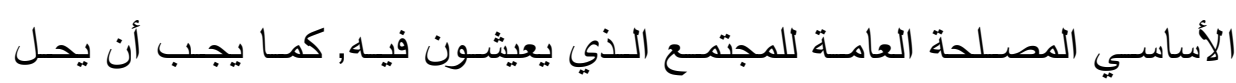
التضامن الإنساني محل المكسب المادي 118.

إن هذا النوع من الاقتصاد سوف يكون لـه وجود فقط في ظل مجتمعات بيئية تحررية لامركزية,لأنه الاقتصاد الوحيد الذي يكون بمقدوره الوقوف في وجهاد لونه

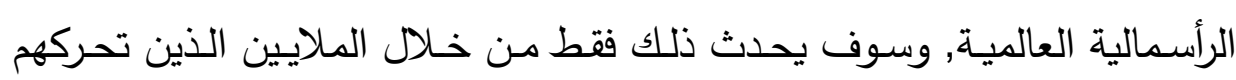

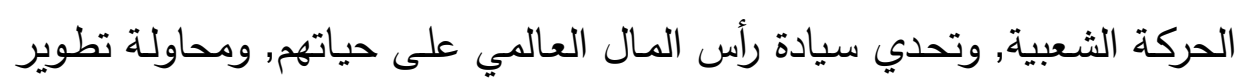

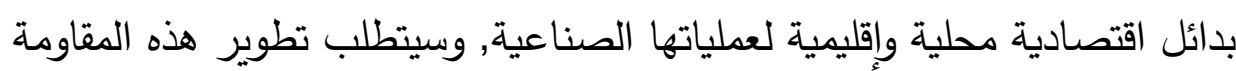

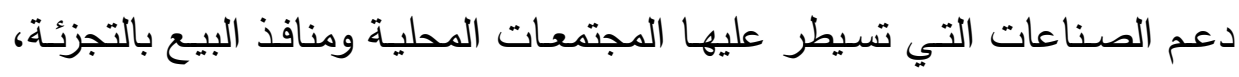

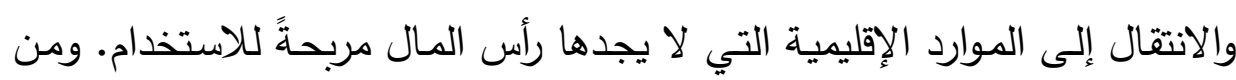

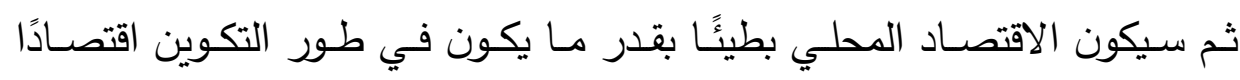

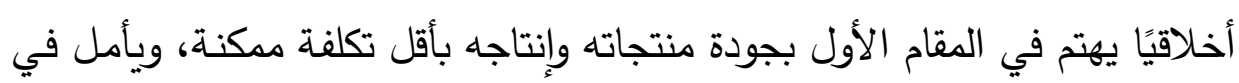

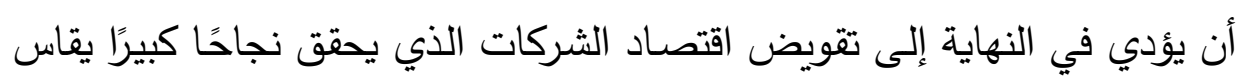

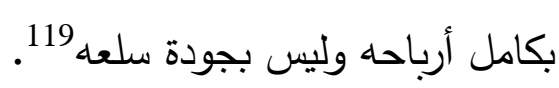




\section{مجلة وادي النيل للاراسات والبحوث الإنسانية والاجتماعية ـ مجلة علمية محكمة}

(ISSN : 2536 - 9555)

ومسن هنـا فـإن اقتصـاد المجتمـع البيأسي التحـرري هـو اقتصـاد يعتمـد في الأسـاس على مشاركة كافـة المواطنين وتعاونهم, ولا يتم تأميمـه أو تجميعـه وفقًا للمبادئ النقابية. ويقترح أن يتم وضـع الأراضي والمؤسسات على نحو متزايد في عهدة المجتمععلى نحو أدقورعاية المواطنين في ظل المجالس شعبية حرة. وعندما يحدث ذلك فقط سوف تتوفر للسلع أعلى درجات الجودة، وسوف تلتزم الاحتياجات بالعقلانية و المعايير البيئية، وسوف تحل معايير التوازن محل المعايير الرأسمالية المتمثلـة في "النمـو أو المـوت". في مثل هذا الاقتصـاد المحلي- الكونفدرالي، والمتـرابط، والعقلانـي بالمعـايير البيئيـة، ولـيس مجـرد التكنولـوجي، سـيتم دمـج المصـالح الخاصـة التي تقسم النـاس اليوم إلى العمال والمهنيين والمديرين، ومـا شـابه ذلك إلـى مصـلحة عامـة يـرى فيهـا النـاس أنفسـهم مـواطنين يسترشـدون باحتياجات مجتمعهم, وليس فقط بميولهم الثخصية ومشاغلهم المهنية. وهنا سيتم التركيز على المواطنة، وستحل التفسيرات العقلانيـة والبيئية للصـالح العام محل المصـالح الطبقيـة والهرميـة. وعليـه فـإن هذا هـو الأسـاس الأخلاقي للاقتصـاد

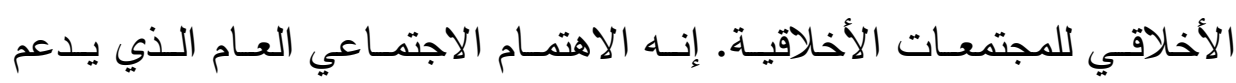
المجتمعات الأخلاقية 120.

إن المجتمـع البيئي التحرري هو سياسـة يمكن أن تثير الخيـال العـام، وهو مناسـب لحركة عقلانيـة تحتاج إلى إحسـاس بالتوجيـه والهدف. تقدم المجتمعات التحررية الأفكار، والطرق، والوسائل، ليس لتغير النظام الاجتماعي الحالي فقط, بل لإعادة تشكيله بشكل جذري، وتوسيع تقاليده الديمقراطية المتبقية إلى مجتمـع عقلاني وبيئي 121.

ولكي يتحقق ذلك يجب أن تكـون مجتمعاتــا الصـغيرة متوازنـة اقتصـاديًا ومستديرة بشكل جيد، بحيث يمكنها الاستفادة الكاملة مـن المواد الخام المحلية 
وموارد الطاقة، لتوسيع المحفزات الزراعية والصناعية. كما يجب تثجيع الناس

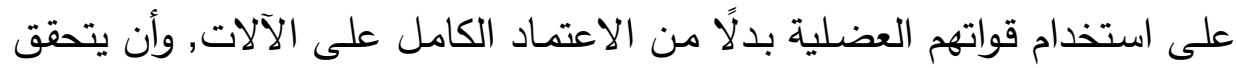

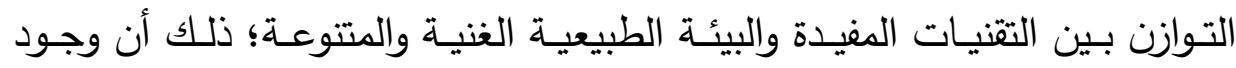

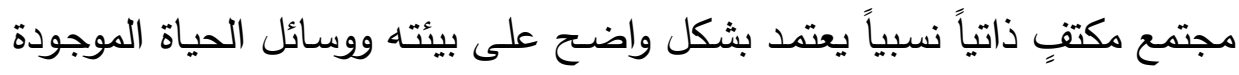

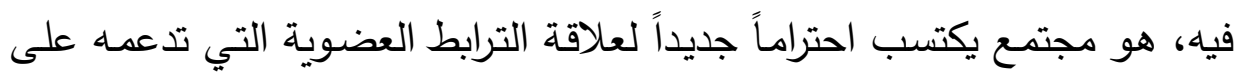

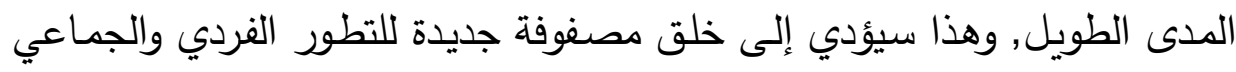
واتحادًا مع البيئة المحيطة التي من شأنها أن تحفز المجتمع 22. وهنا يؤكد موري بوكتثين أن عبارة "العيش مع" لا تتضمن إحساسًا عميقًا

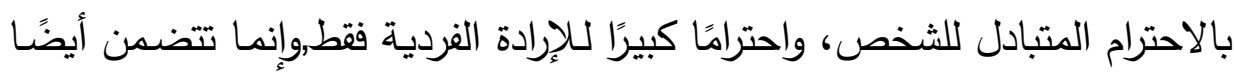

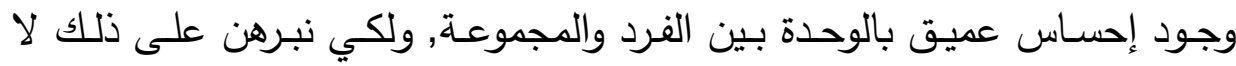

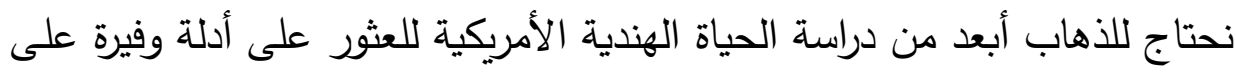
هذه الحقيقة, حيث كان المجتمع الهندي التقليدي موجهًا بالكامل نحو التضـامن

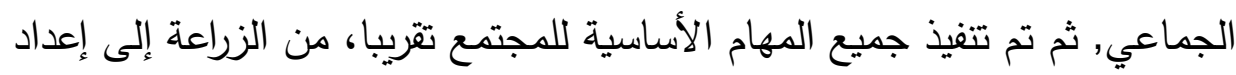

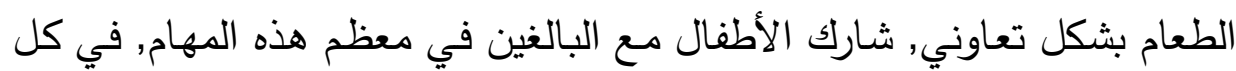
مرحلة عمرية يكون الفرد مكلفًا بشعور بالمسئولية تجاه المجتمع. ومن هذا الثعور لئين

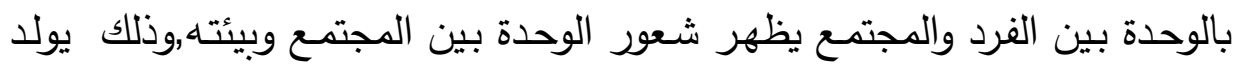

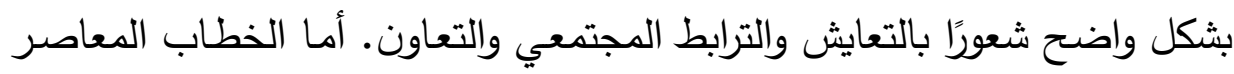
فيميل إلى طمس ثروة الآثار المترتبة على اندماج الفرد والمجتمع والبيئة في نظام واحد متوازن 123.

إننا ملزمون بالعودة إلى الثقافات الأخرى ليس من أجل قيم إنسانية أكثر ،

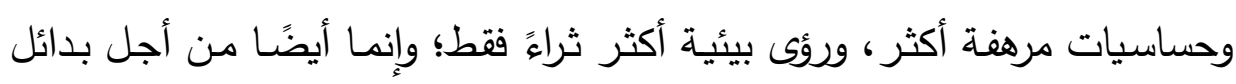




\section{مجلة وادي النيل للاراسات والبحوث الإنسانية والاجتماعية ـ مجلة علمية محكمة}

(ISSN : 2536 - 9555)

تقنية لقوى الإنتاج الضخمة "المربكة" القوى التي بدأت تقهرنا بالفعل وتهدد سلامة الحياة على هذا الكوكب 124.

وهنا يؤكد بوكتثين أنه لا يعترض على انتشار الحرفين, والادوات, والتقنيات

الجديدة, والتطور الواسـع والمكثف لتفاعلات السوق الحميمة بشكل عام وجوانبها الإنسانية والأخلاقية, فإن هذا المزيج الغني من العلاقات التجاريـة يعزز التفاعل البشري على عكس النمط الرأسمالي لاقتصاد السوق الموجود في عصرنا الراهن, فإن التجارة على نطاق صغير محلي بين المجتمعات والأفراد المرتبطين بها بشكل

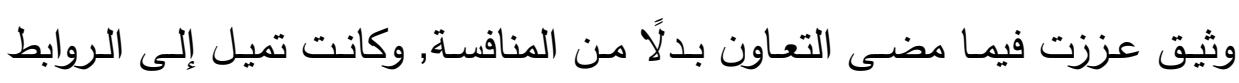
المحلية وتوسيعها بـدلًا من قطعها كانت قائمسة على المشـاركة أكثر مـن كونها عدائية أخلاقية أكثر من كونها مفترسة, ومن الناحية السياسية قدمت منتجًا فرديًا بقاعدة ماديـة أقوى لممارسـة المواطنة, وأخيرًا كانت تميل إلى حل الحواجز بين المجتمعات المحلية والمناطق المجاورة, مما يفتح الأبواب أمام الأفكار والثقافات والقيم, وتبادل المهارات والتقنيات 125.

يتضـح من ذلك أن اقتصـاد المجتمع البيئي التحرري يكون فيه لكل مواطن نصيبه وحصـته, وعندما يحدث ذلك سيتم تعزيز أجـواء نفسية جديدة إحساسـاً بالولاء والمسؤولية المدنية, مما يجعل كل مواطن يشعر بأنه ملتزم بنجاح الاقتصاد الأخلاقي. وبذلك سيشعر المواطنون بأن لهم مصلحة شخصية في تحقيق رفاهية هذا المجتمع, وعليه فمن المرجح ألا تنجح أي من هذه المشاريع التحرريـة إذا لم تكن السياسة الجديدة تربوية، وفي الواقع إذا لم تكن شكلًا جديدًا من أشكال التتوير المدني الذي يتمكن فيه المواطن من خلق مجتمع بيئي تحرري 126. وهنا يتفق موري بوكتشين مع هارولا لاسكي (1893) (Harold Laski) 1950) الذي أكدأنه يجب أن يكون هناك اتساع لدائرة المجال الاقتصادي, فلا 
يجب أن يكون قاصرًا على فئة بعينها تحتكر هذا المجال, وتحتكر كل استفادة منه, وعندما يحدث ذلك فقط سوف يشعر الجميع بأن هناك فرصًا حقيقية يوفرها لهم مجتمعهم لكي يحيوا الحياة التي يستحقونها 127.

ويتقق أيضا مع إدغار موران الذي أكد أن الاقتصاد لا ينبخي أن يخضع للتقنين فحسب, بل ينبغي أن يصير اقتصادًا جماعيًا يتسع للتعاضديات, والجمعيات, والتعاونيات, وتبادل الخدمات 128 . ويتفق كذلك مع دوركين الذي أكد أن مجتمع المواطنين المتكاملين سيحقق بشكل حتمي مجتمعًا أكثر عدالة من المجتمع غير المتكامل 129.

وإذا كان هذا هو ما يتعلق بالثكل الاقتصادي الخاص بالمجتمع البيئي التحرري ماذا عن شكله الاجتماعي؟ ويجيب موري بوكتشين عن هذا التساؤل بأنه الثكل الذي يقوم على الروابط والعلاقات الحميمة بين كافة أعضائه, والذي تسوده روح التعاون, ولكي يحدث ذلك يجب أن يخضع هذا المجتمع لتغييرات هيكلية عميقة عن طريق استبدال المنافسة بالتعاون، والبحث عن الربح بالعلاقات القائمة على المشاركة والاهتمام المتبادل. وسوف يتطلب ذلك حركة اجتماعية منظمة، وواعية وواضحة، ومتجهة إلى الأمام، من أجل مواجهة التحديات الأساسية التي يطرحها مجتمعنا الراهن الذي يتتاقض مع المجتمع البيئي التحرري. إننا بوصفنا أفرادًا يجب أن نغيّر أنماط حياتتا قدر الإمكان, ولكن ليس هذا كل شيء نحن بحاجة إلى إعادة هيكلة المجتمع بأكمله، حتى ونحن نشارك في تغيير نمط الحياة بنضالات منفردة ضد التلوث، ومحطات الطاقة النووية، والاستخدام المفرط للوقود الحفري، وتدمير التربة، وما إلى ذلك. يجب أن يكون لدينا تحليل متماسك للعلاقات الهرمية العميقة وأنظمة الهيمنة، إضافة إلى العلاقات الطبقية 
والاستغلال الاقتصادي الذييحط من قدر الناس وكذلك البيئة, ولكي يكون بإمكاننا إعادة بناء المجتمع على أسس مختلفة قوامها التعاون والترابط والمشاركة ولكي يتحقق ذلك يجب أن تلعب العوامـل التقافيـة دورًا رئيسًا في تشكل المجتمع البيئي التحرري, ويجب أن تكون تربـة خصبة لنشر الوعي, وترسيخ قيم التعددية والتعاون والتتوع من أجل مجتمع قادرٍ على تلبية الاحتياجات والرغبات البيئية والإنسانية

إذا تم تحقيـق المجتمـع البيئي التحرري مـن الناحيـة العمليـة، فـإن الحيـاة الاجتماعية ستتتج تطوراً حساساً للتنوع البشري والطبيعي، وتقع في كتلة متتاغمـة جيدة التوازن بين البيئة الطبيعية والإنسانية. وسيصبح المجتمع مجالًا خصبًا لكل تطوير بناء وإمكانات فريدة وخلاقة, وسيؤدي ذلك إلى فتح آفاق مجموعة واسعة

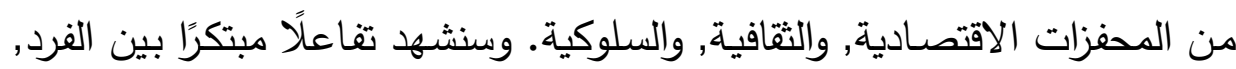
والمجتمع, والبيئة, والإنسانية, والطبيعة. وسيتم احترام الاختلافات بين الناس، بل وتعزيزها بوصفها خبرات إنسانية حية يجب أن يتم الاستفادة منها في بنا المجتمع البيئي التحرري. هذا الإحساس بالوحدة سيعكس تشابك المصـالح بين الأفراد وبين المجتمع والطبيعـة. وسيتم تحريرهم من روتين قمعي، ومن عمليات القهع وعدم الأمان، ومن أعباء الكدح والاحتياجات الزائفة، ومن عوائق السلطة والإكراه غير العقلانـي، وسـيكون الأفراد في النهايـة في وضـع يســح لهم بتحقيـق إمكانـاتهم كأعضاء في المجتمع البشري والعالم الطبيعي 132. وهنا يتفق موري بوكتشين مع رولز الذي دافع عن المجتمع جيد التنظيم, والذي في ظله يدرك الأفراد حاجاتهم بعضهم إلى بعض بوصفهم شركاء, ويدرك

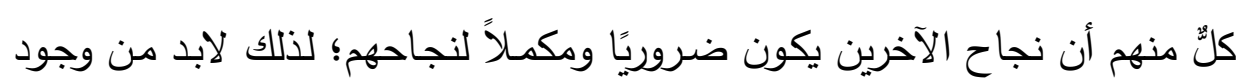
مجتمـع متعـاون يشـترك فيـه كل أفراده لإنجاحـه لكي يكـون قـادرًا على أن يفي لـي 
بمتطلباتهر, وبأن يحقق أهدافهم وطموحاتهم مهما اختلفت وتثعبت. وبذلك سوف

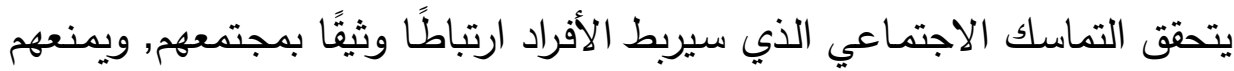
من تدمير بعضهم بعض 133.

ويتفق أيضـا مـع دوركين الذي أكد أن حياة المواطن تكون مرتبطة بالحياة

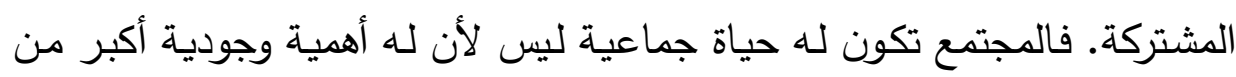

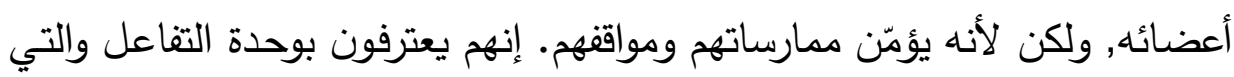

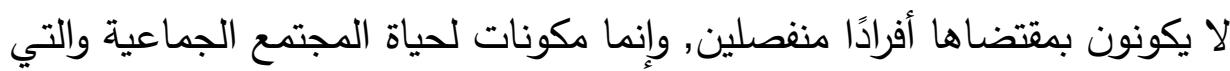

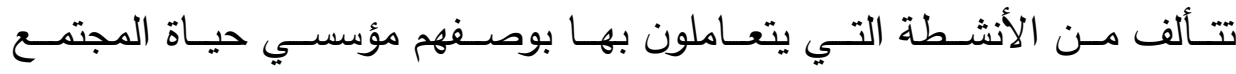
الجماعية.ولايعني التكامل مجرد التصريح فقط بأنني جزء من هذا المجتمع, وإنما يعني التكامل أن أكون مرتبطًا بهذا المجتمع بشكل فعلي, لكي يكون من الملائم أن أنظرإلى نفسي على أنني متكامل أخلاقيًا مع أفعاله 134.

وإذا تساءلنا عن الثكل البيئي والإنساني للمجتمع البيئي التحرري نجد أنها

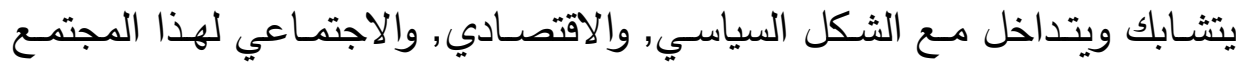

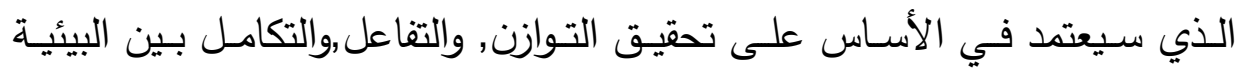

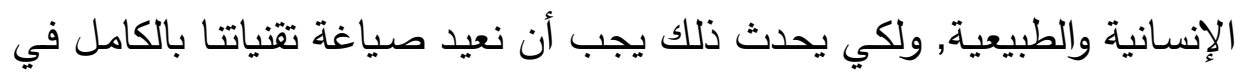

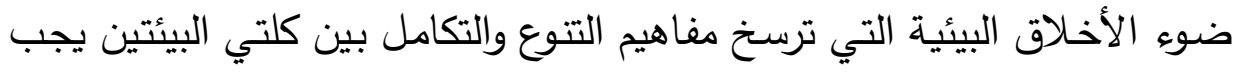

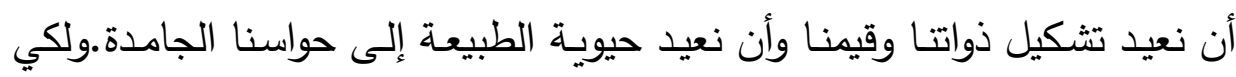

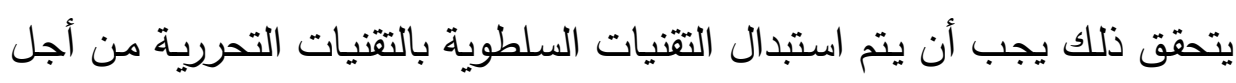

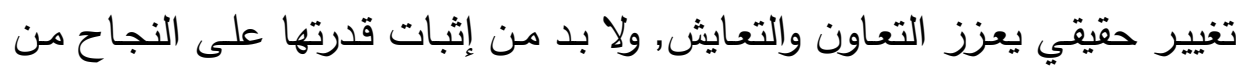

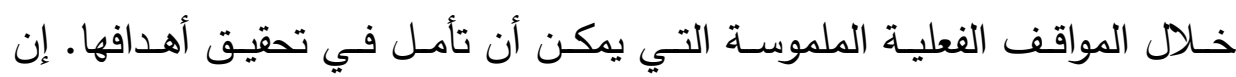

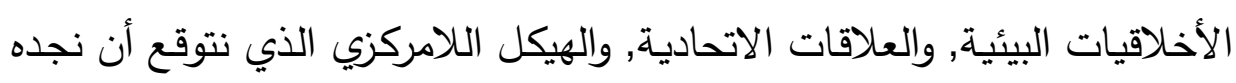


في مجتمع مستقبلي، تعززه القيم والثبكات التي نحاول استخدامها في تحقيق مجتمع بيئي تحرري 135.

هنا يتفق موري بوكتشين مـع هيربرت مـاركيوز الذي أكد أنتا لكي نحافظ على "المزايا الإنسانية" للوجود البشري من المهح أيضًا كل الأهمية أن تتيح البيئة تلبية الرغبـة في الحياة بسـلام, ووداد حميم, واستقلال. ولكي يصبح في مقدور العلم والتكنولوجيا أن يكونـا عاملي تحرير عليهــا أن يبدلا اتجاههما وأغراضهها الراهنة, وعليهما أن يتجددا طبقًا لحساسية جديدة, أي طبقً الأوامر النبضـات في الحياة الجديدة ومقتضياتها الملزمـة. وعندئذ يمكن الحديث عن تكنولوجية تحرير تكون ثمرة خيال علمي حر , ومن ثم يمكن تصور أشكال لكون بشري ينتفي منه الاستغلال والعمل الثاق. هذه الحساسية الجديدة التي تعلن أسبقية نبضـات الحياة في الوجود على الروح العدوانية تستطيع أن تجعل من إلغاء الظلم والبؤس شينًا حيويَّا للمجتمع, وتوجها لتطور النهائي برمتـه ل "نموذج الحياة", وسيصبح في وسـع الوجدان, والتكنولوجيـا, والعلم الجديـد بفضـل تحريرهـا أن تكثـف إمكانـات الناس والأشياء التي تحمي الحياة وتغنيهان

ويتقق أيضـا مـع إريك فروم الذي أكد أن الحريـة الإيجابية تقوم في النشاط التلقائي للشخصية الكليـة المتكاملة, وبذلك سيتحد الإنسـان مـن جديد مـع العالم الطبيعي ومع ذاته137. إن الهدف هذه المرة ليس هو السيطرة على الطبيعة, وإنما هو السيطرة على التكنولوجيا, وعلى القوى والمؤسسات الاجتماعية اللاعقلانيـة التي تهدد البقاء المادي للمجتمع الغربي, بل تهدد بقاء الجنس البشري كله؛ لذا فإنــه لا مستقبل لنـا إلا إذا وعـى المفكرون أبعـاد الأزمــة الراهنـة, وعبـأ طاقـاتهم, وكرسوا جهودهم المشتركة من أجل هذا العلم الإنساني الجديد 138. 
إن ما ينشده موري بوكتثين هو البحث عن مجتمع حر حقا مؤسس على

مبادئ بيئية يمكن أن يوفق بين العلاقـة بين علاقات البشر بالطبيعـة. وسوف يتطلب ذلك تطوير تكنولوجيا جديدة تركز على فهم الأبعاد البشرية, مثل هذه التكنولوجيـا التـي تشـمل المنشـآت الصــيرة للطاقـة الثمسـية والريـاح، والحـدائق العضـوية والاسـتفادة مـن المـوارد الطبيعيـة المحليـة التـي يـتم عملهـا مـن قبـل مجتمعات لا مركزية. ولن يتحقق ذلك إلا في ظل ديمقراطية مباشرة, ولا مركزيـة حضارية, ودرجة كبيرة من الاكتفاء الذاتي, وهو تمكين ذاتي القائم على الأنماط المشتركة من الحياة الاجتماعيـة. إنـه المجتمع اللاسلطوي المؤلف من تجمعات شعبية صغيرة يهدف المجتمع البيئي التحرري إلى حل المشاكل التي وصلت إلى طـابع كارثي وعالمي وشـامل بيئًا وإنسـانيًا, وسـوف يتحقق ذلك من خـلال فهم أعمق لنطاق التغييرات الضرورية التي لا غنى عنها ليصبح هذا المجتمع حقيقة حية ملموسة

يتطلب المجتمع البيئي التحرري أيضـا المشـاركة في مشروع بيئي مشترك لإعادة التوحيد والتعاضد؛ لذا يجب علينا إعادة إدخال التطور الطبيعي ليس فقط لننجو من آفاق الكارثة البيئية والتضـحية النوويـة ولكن أيضًا لاستعادة خصوبتـا في عـالم الحيـاة. لا يعني ذلك أن علينـا العـودة إلى الطـرق البدائيـة لأسـلافنا الأقدمين وإنما يعني بالأحرى إضفاء الطابع العقلاني والبيئي على تقنياتنا وتقدمنا التكنولوجي, ومن ثم يجب أن نستعيد إرث الحريـة الذي سـى إرث الهيمنـة إلى استئصساله من ذاكرة الإنسانية140. يجب أن نكون على وعي بأنه من المستحيل تحقيق انسجام بين الناس والطبيعة دون خلق مجتمع بشري يعيش في توازن دائم مع بيئته الطبيعية 141. - م 


\section{الفـاتمة}

حاول هذا البحث تقديم تصـور موري بوكتثين للمجتمع البيئي الإنساني الذي انطلق فيه من مبدأ أساسي هو تحقيق التوازن, والتفاعل, والتكامل بين البيئة

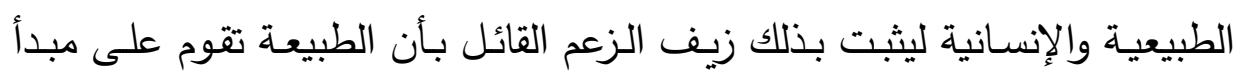

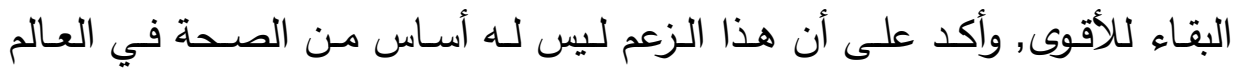

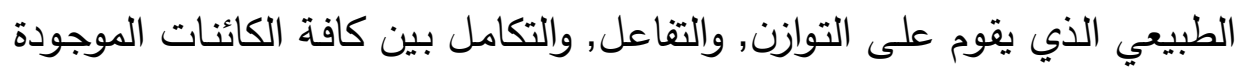

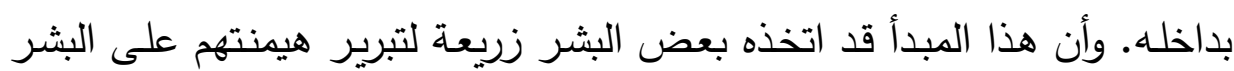

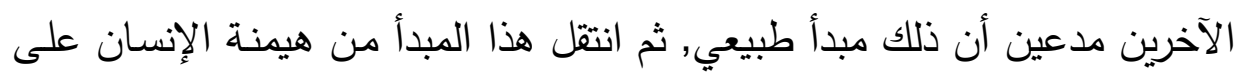
الإنسان إلى هيمنة الإنسان على الطبيعة, وقد أدى هذا المبدأ إلى تدمير البيائتين

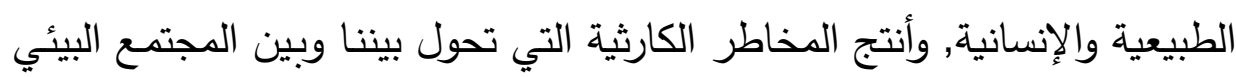

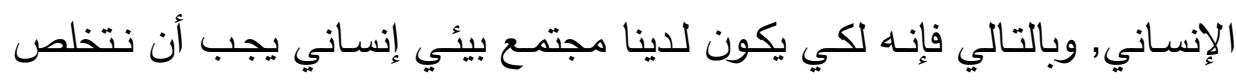

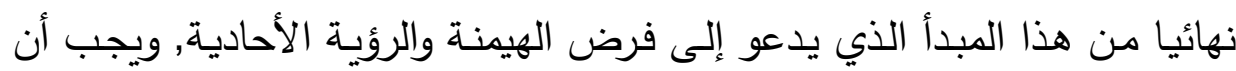

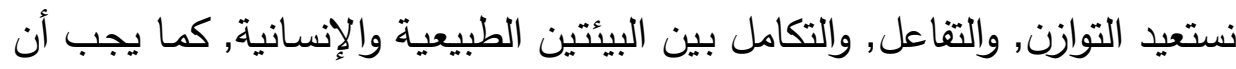

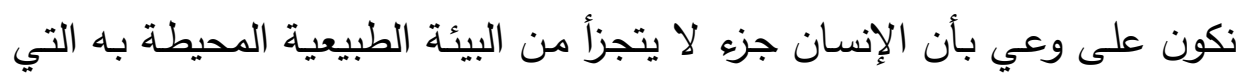

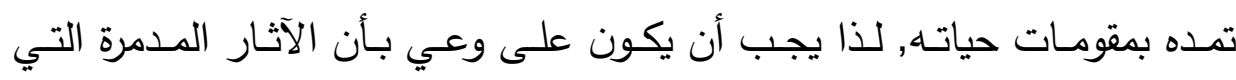

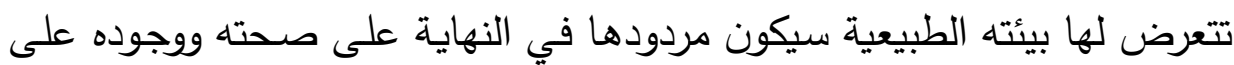

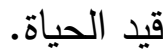

وعندما نـدرك أهميـة وجود هذا التعـايش والتـوازن بين البيئتين الإنسـانية والطبيعية سوف نتمكن من القضـاء على المخاطر والمعوقات التي تحول بينتا وبين المجتمع البيئي الإنساني والتي على رأسها التحضر المبالغ فيه واللامسؤول

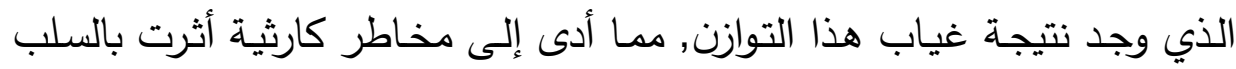


على حياة الإنسان وهددت بقاءه على هذا الكوكب فقد تعرضت مقومات الحياة

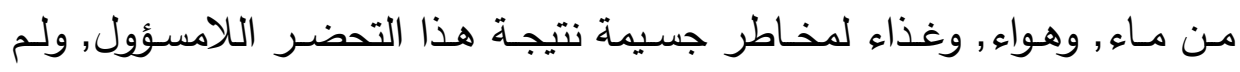
يقتصر الأمر عند هذا الحد وإنما شمل هذا التدهور أيضا زراعة المواد الغذائية وصـاعتها, وذلك من خـلال العدد الهائل مـن الملوثات الذي تتعرض لـه بيئة الإنسان الطبيعية في كل لحظة نتيجة هذا التقدم اللامسؤول, وبالتالي أصبحت وند صحة الإنسان مهددة بالإصـابة بالكثير من الأمراض المزمنة التي لم يسبق لها لهابل مثيل من قبل وأصبحت حياته مهددة بالمخاطر التي تتزايد في كل لحظة. ولكي نتخلص من هذه المخاطر التي تتزايد في كل لحظة يجب أن نستعيد هذا التوازن المفقود بين البيئة الإنسانية والطبيعية من خلال بيئة اجتماعية واعية قادرة على إرساء قيم التتوع, والتلقائية, والتوازن, والتكامل ولكي يتحقق ذلك لا بد من وجود مجتهع مدني يحل محل الدولـة المركزيـة التي أصبحت في في عصدرنا

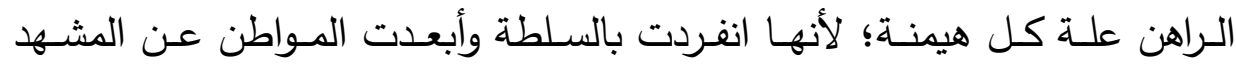

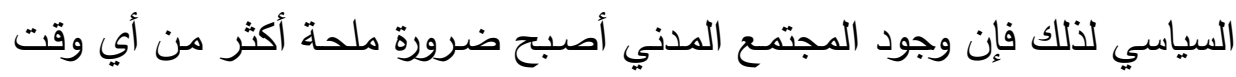

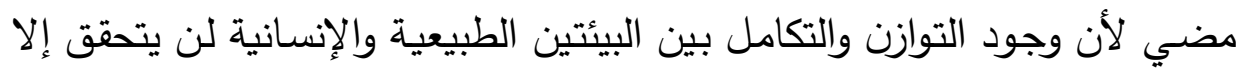

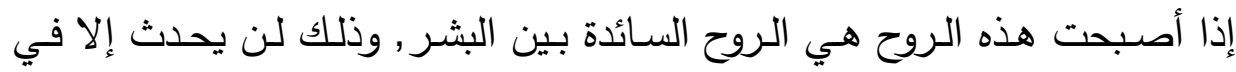
وجود المجتهـع الـدني الذي يقوم على روح التعـاون, والتعـايش, والتكامل بـين البشر , ولا يكون به وجود للهيمنة والانغراد بالسلطة؛ لأن السلطة ستكون سلطة كل

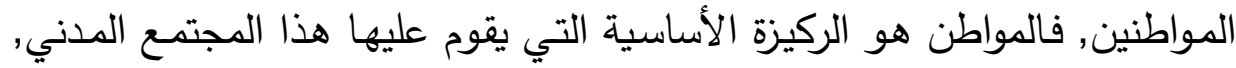
والذي سيتعاون مع أقرانه من المواطنين لصنع سياسة مجتمعهر. وبالتالي فإن المجتمع المدني هو التربة الخصبة التي ستتبت المجتمع البيئي

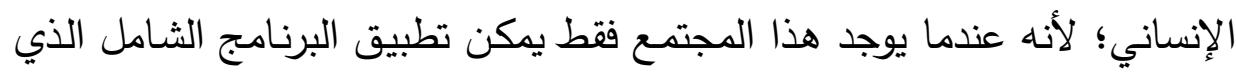
سيؤدي إلى تـدعيم وجـود هذا المجتمـع مـن خـال تثـابك العوامـل السياسـية. 
والاقتصـادية, والاجتماعيـة, والبيئيـة, والإنسـانية وترابطهـا وتـداخلها الأمـر الذي يجعل هذا المجتمع حقيقية ملموسة, والتي يكون كل منها جزيًا لا يتجزأ من الآخر لأن هدفها واحد هو تحقيق التوازن والتكامل بين البيئتين الطبيعية والإنسانية من أجل مجتمع بيئي إنساني.

فإذا نظرنا إلى السياسة الحقيقية التي يجب أن يقوم عليها هذا المجتمع نجد أنها السياسـة القائمـة على الديمقراطيـة المباشـرة التي ترتكز في الأسـاس على السلطة الشعبية التي سيتمكن من خلالها كافة المواطنين من الحوار والنقاش, في كل مـا يخص قضـاياهم العامـة للتوصل إلى قراراتبشـأنها روبالتالي ستصبح سياسـة المجتمع مسئولية هؤلاء المواطنين. ومـا ينطبـق على السياسـة ينطبـق أيضـا على الاقتصـاد إذ إنـه الاقتصـاد الأخلاقي الذي سيوفر للمواطنين احتياجاتهم الضرورية والحقيقية, والذي سيكون لكـل مـواطن حصــة ونصـيب فيـهـوولن يكـون مقتصـر على فئسة بعينهـا, وإنمـا ستتضافر جهود كافة المواطنين لتحقيق الازدهار الاقتصادي لمجتمعه. وما ينطبق على السياسـة والاقتصـاد ينطبق أيضـا على الشكل الاجتمـاعي لهذا المجتمعـ, حيث إنـا المجتمع التي تسوده روح التعاون, والتعـايش, والتكاتف بين كافـة أعضـائه, وهو المجتمع الذي يقوم على التضـامن والثـور بالمسؤولية التي يكون قوامها المشاركة والترابط من كافة أعضائه.

ونفس الثـيء ينطبق على الثكل البيئي والإنساني لهذا المجتمع المحصلة النهائية لهذا المجتمع بما سيحققه من توازن حقيقي بين البيئة الطبيعية والإنسانية؛ حيث يستعيد الإنسان قيمته بوصفه كائنًا حيَّا يحافظ على بيئته الطبيعية, ويكف عنها كل ما يؤدي إلى تدميرها وتشويها لأنه قد أصبح على وعي بأهميتها وبأن 
العلاقة بينـه وبينها هي علاقة توازن وتكامل, وليست بأي حال علاقة تعارض

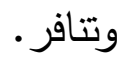

وفي النهاية فإن هناك العديد من الجوانب المضيئة التي يمكن استخلاصـاها

من المحاولة التي قدمها موري بوكتشين لرسم معالم مجتمع بيئي إنساني يمكن أن تعينتا على التخلص من الكثير من الأزمات والمشكلات الموجودة في عصـرنا الراهن, وأهم هذه الجوانب:

1- التأكيد على ضرورة استعادة التوازن, والتفاعل, والتكامل بين البيئة

الطبيعية والبيئة الإنسانية, والتتبيه إلى المخاطر التي نتجت من غياب هذا التوازن على كل المستويات البيئية والإنسانية, والتأكيد على ضرورة القضاء عليها من خلال إحداث تغييرات واقعية ملموسة تجعل وجود هذا المجتمع البيئي الإنساني حقيقة حية على أرض الواقع. 2- التأكيد على أنه من أهم أسباب الاغتراب الإنساني, وبالتالي من أهم أسباب الفشل في تحقيق تتمية اجتماعية وإنسانية حقيقية هو ادعاء البساطة والتخصص المفرد, والاستقلالية الزائفة, فقد أصبح مجتمعنا يتآلف من دوائر ومجالات منفصلة ومستقلة بعضها عن بعض فأصبحنا ننظر إلى السياسة على أن لها عالمها الخاص, وإلى له الاقتصاد على أنه عالم ثانٍ مستقل عن الأول, وإلى الشئون الاجتماعية على أنها عالم ثالث لا علاقة له بالعالمين السابقين, ولم يقتصر الأمر على ذلك وإنما امتدد ليشمل كل أمور حياتتا, واهتماماتتا, ورغباتتا, وميولنا التي تحولت جميعها إلى عوالم منفصلة بعضها عن بعض ولا يوجد بينهم أي قواسم مشتركة, ونسينا أن التتمية الاجتماعية والإنسانية 
الحقيقية التي يكون هدفها أن يحيا الإنسان الحياة الكريمة التي يستحق أن يحياها تقوم في الأساس على تداخل كل هذه المجالات والاهتمامات وتفاعلها وتكاملها, حيث يؤدي كل منها إلى الآخر في شبكة مترابطة تعتمد في الأساس على وجود قواسم مشتركة فالسياسة لا تتفصل عن الاقتصاد وكلاهما لا ينفصل عن حياة الانسان الاجتماعية, وكذلك تعليمه وصحته وبيئته الطبيعية التي يجب أن يتعامل معها بالتفاعل والتتوع والتكامل, فهذا هو سبيلنا لتحقيق تنمية حقيقية من أجل مجتمع بيئي إنساني. 3- إن الديمقراطية الحقيقية لا تنشأ من فراغ, وإنما تكون نتيجة تكاتف جهود واعية صادقة, فإنه ليس من الصعب تحقيق الديمقراطية على الأرض الواقع إذا امتلك البشر إرادة حقيقية يمكن أن يحولوا المعاناة والمظالم التي يعانوا منها إلى إصرار وعزيمة حقيقية تمكنهم من أن يجعلوا الديمقراطية واقعًا حيَّا ملموسًا, ويعينهم على ذلك قادة مخلصون يؤمنون بقضيتهم ويدافعون عنها, وعندما يحدث ذلك فقط سوف تتحول هذه الإرادة إلى ممارسة حقيقية فعلية. 4- إن الديمقراطية الحقيقية والمجتمع المدني المنشود ليس مسئولية فرد بعينة, وإنما هو جهد متواصل يأتي فيه اللاحق ليكمل مسيرة السابق, إذ إنها تحتاج إلى صبر وقدرة على تحمل الصعاب, وإصرار على مواصلة الجهود لكي تصبح حقيقة حية ملموسة.

5- التأكيد على دور المهم والفعال الذي يمكن أن يقوم به الفن في ترسيخ دعائم المجتمع المدني والديمقراطية الحقيقية. 
6- الاهتمام بالجانب التربوي التعليمي التثقيفي الذي سيؤدي إلى وجود ثقافة اجتماعية واعية يتم تثكيلها من خلال اجتماع المفكرين, والفنانين, والثعراء, والسياسيين, والمواطنين العاديين, والذي يؤدي إلى إرساء لهاء ثقافة ديمقراطية حقيقية واعية تقوم على تبادل الخبرات والآراء , وبالتالي والي ولئي يتم من خلالها تكوين ثقافة حية يتفاعل ويشارك فيها كل المواطنين لتحقيق الصالح العام الذي يكون كل واحد منهم جزءًا لا يتجزأ منه. لئه 7- التأكيد على ضرورة الربط بين الماضي والحاضر والمستقبل, والتأكيد على أنه لا يمكن أن يكون هناك وجود للمجتمع البيئي الإنساني إلا لإني

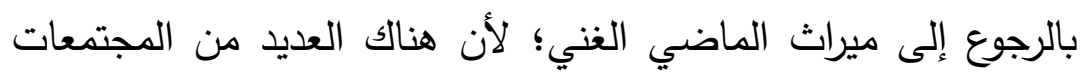

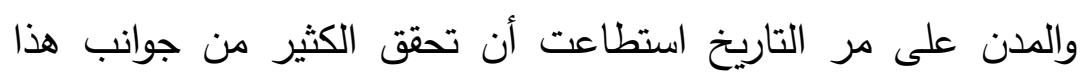
المجتمع البيئي الإنساني وأن محاولة قطع صلتتا بالماضي هو تثويه الحاضر وضياع لملامح المستقبل.

8- تقديم برنامج شامل يمكن الاسترشاد به في تحقيق المجتمع البيئي

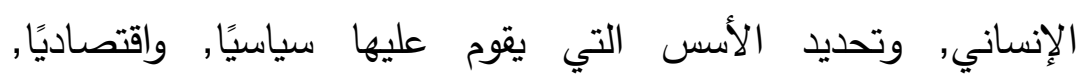
واجتماعيًا, وبيئيًا, وإنسانيًا.

9- إن الثيء الوحيد الذي ربما يؤخذ على موري بوكتثين هو أنه مفكر

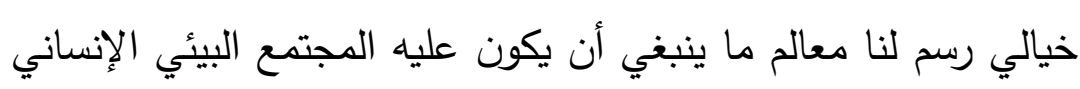

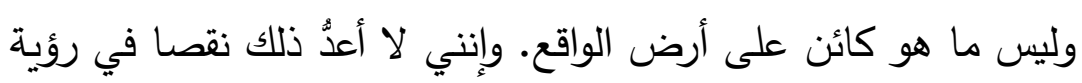

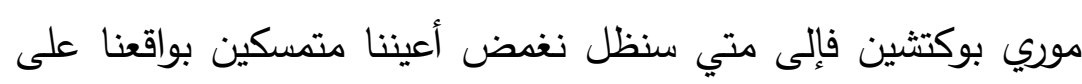
الرغم ما به من مساوئ وعيوب, ونرفض أي محاولة لتغييره بحجة أنها

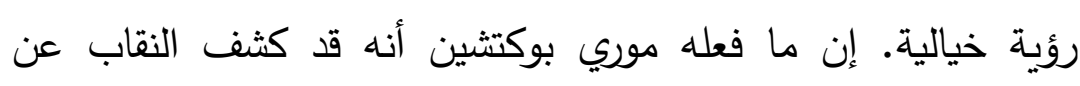


مساوئ واقعنا, وقدم لنا صورة حية لهذا الواقع بلا تزيف ولا تجميل, ثم قدم لنا الخطوط الإرشادية التي يمكن أن نستعين بها لتغيير هذا الواقع السيئ من أجل مجتمع بيئي إنساني يمكن أن يتحول إلى واقع حي ملموس إذا أردنا نحن ذلك. ولا عجب في ذلك فإننا إذا نظرنا إلى كل الاكتثافات, والاختراعات, والإنجازات التي تحققت نجد أنها كانت في يوم من الأيام حلم وتحول إلى واقع. كما أننا نتساءل هل الخراب والتذمير والتشويه الذي تعاني منه البيئة الإنسانية والطبيعية أصبح هو الواقع الذي ندافع عنه وأصبحت كل محاولة للقضاء على هذا التشويه والتدمير يتم وصفها بأنها رؤية خيالية لقد بدأ موري بوكتشين بتقديم تحليل وافٍ للواقع المعيش بكل أزماته ومشكلاته البيئية والإنسانية, وقدم لنا حلولا يمكن بالإرادة والإصرار أن تصبح واقع حي ملموس يتحقق في ظله مجتمع بيئي إنساني.

وأخيـرًا اوادُّ أن أقول كلمـة واحدة هـي الـوعي, فـإن كل أزماتتـا ومشكلاتتا

الراهنـة يمكـن إرجاعهـا إلىى غيـاب الـوعي؛ فبغيـاب الـوعي لا يواجـه الإنسـان مشكلاته وأزماته, ومن ثم لا يبحث عن حلول فعالة للقضاء عليها والتخلص منها. فإذا أردنـا معالجـة حقيقيـة لكل مشكلاتتا وأزماتتا فليس هنـاك بديل عن الوعي؛ فالوعي بالمشكلات سيكون هو الدافع الذي سيؤدي إلى البحث عن حلول بناءة لها, وبالتالي فإن حلم موري بوكتشين وحلمنا معه بمجتمع بيئي إنساني لن يتحقق إلا من خـلال الوعي بالمخاطر التي تحول بينتا وبين تحقيق مثل هذا المجتمع, والوعي بضـرورة مواجهتها والقضــاء عليها, ثـم الوعي بـأن هذا المجتمـع البيئي الإنساني أصبح ضرورة ملحة لا غنى عنها. 

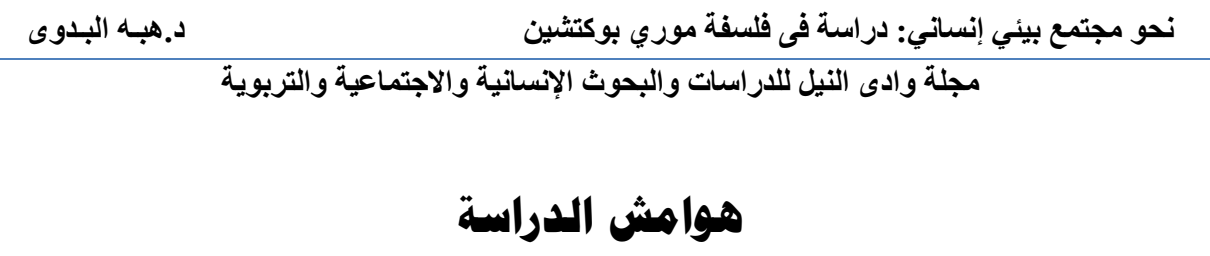

1 - Murray Bookchin, The Communalist Project, 2002, In The Next Revolution :Popular Assemblies And The Promise Of Direct Democracy, Introduction By Debbie Bookchin And Blair Taylor, Verso Books,London,2015,P.17.

2 - Murray Bookchin,Our Synthetic Environment,Knopf,the University Of Michigan ,1962,P.2.

3- Ibid, P.2.

4 -Ibid, P. 11,22.

5- Murray Bookcin, The Ecology Of Freedom, Cheshire Books,USA,1982,P.18,19.

6-Ibid,P.366.

7-Murray Bookchin, The Next Revolution :Popular Assemblies And The Promise Of Direct Democracy, Introduction By Debbie Bookchin And Blair Taylor ,P.10.

8-Murray Bookchin,Ecology And Revolutionary Thought, GoddardCollege,1965,P. 23.

9-Ibid,P. 25,27.

10-Murray Bookchin, Our Synthetic Environment, P.31,32.

11-Ibid,P.33.

12-Murray Bookchin,Ecology And Revolutionary Thought,P. 24.

13-Murray Bookchin, Our Synthetic Environment, P.34.

14-Ibid,P.36,37.

15-Ibid,P. 37-39.

16-Ibid,P.48.

17-Ibid, P.13-15.

18-Ibid,P.16,17,22.

19-Ibid,P.23,24.

20-Murray Bookchin,Ecology And Revolutionary Thought,P.28.

21-Murray Bookchin,Our Synthetic Environment, P.2,3.

22I-bid,P.4,8

23-Ibid,P.10.

71 


\section{4-Ibid,P.4,5,12.}

25-Murray Bookchin,Our Synthetic Environment, P.62,66.

26-Ibid,P.70,76,77.

27-Murray Bookchin,Ecology And Revolutionary Thought,P.29.

28-Murray Bookcin,The Ecology Of Freedom, P.219,220

29-Ibid,P.222.

30-Ibid,P.224,237.

31-Ibid,P.239,240.

32-Ibid, P.244-245.

33-برتراند راسل, السلطة والفرد, ترجمة: شاهر الحمود, بيروت, دار الطليعة للطباعة والنشر ,

$$
\text { 1961, ص } 104
$$

34- ماكس هوركهايمر , ثيودور • ف. أدورنو, جدل التتوير شذرات فلسفية, ترجمة: جورج

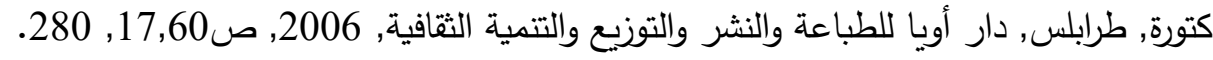

35- هربرت ماركوز , الحب والحضارة, ترجمة: مطاع صفدي, بيروت, دار الآداب للنشر

$$
\text { والتوزيع, ط2, 2007, صربت ماركون 106, } 107 .
$$

36- ليو شتراوس وجوزيف كروبسي, تاريخ الفلسفة السياسية, الجزء الثاني من جون لوك إلى هيدجر , ترجمة: محمود سيد أحمد, مراجعة: إمام عبد الفتاح, القاهرة, المجلس الأعلى للثقافة,

$$
\text { .537. 2005 }
$$

$$
\text { 37-إريك فروم, المجتمع السوي, ترجمة: محمود محمود, 2009, ص483. }
$$

38- حنة آرندت، في العنف، ترجمة: إبراهيم العريس، بيروت، دار الساقي، 1992, ص

$$
.77,76
$$

39-جاك أيلول, خدعة التكنولوجيا, ترجمة: فاطمة نصر , القاهرة, دار سطور, 2004, ص

$$
.260
$$

40- إدغار موران، هل نسير إلى الهاوية؟، ترجمة: عبد الرحيم حزل، الدار البيضاء

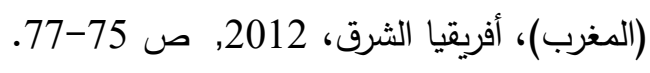

41- آلان تورين، نقد الحداثة، ترجمة: أنور مغيث، القاهرة، المجلس الأعلى للثقافة،

$$
\text { 1997, ص 472, } 473 .
$$


نحو مجتمع بيئي إنساني: دراسة فى فلسفة موري بوكتثين

42- ميثيل فوكو، إرادة المعرفة، ترجمة مطاع صفدي و جورج صالح, بيروت, مركز

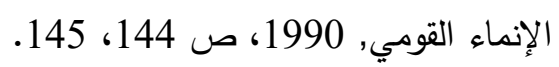

43-Murray Bookcin ,The Ecology Of Freedom, p.20-21.

44-Ibid,p.22- 24.

45-Ibid,P.25, 26.

46-Ibid,P.34,36,37.

47-Ibid,P.41-43.

48-Murray Bookchin, The Communalist Project,P.17-18.

49-Murray bookcin,The Ecology Of Freedom, p.18.

.50-Murray Bookchin,Ecology And Revolutionary Thought,p. 25-26.

51-Ibid,P.27

52-Murray Bookchin,Urbanization Without Cities,Black Rose Book, 1992,P.7.

53-Ibid,P.9, 10.

54-Ibid,P215,216.

55-Murray Bookcin,The Ecology Of Freedom, P.350.

56-Ibid,P. 94,95.

57-Ibid,P. 116,117.

58-Ibid,P. 127,128.

59-Murray Bookchin, Urbanization Without Cities,P.54.

60-Ibid,P.125,132,134.

61-هربارت ماركوز، الإنسان ذو البعد الواحد، ترجمة جورج طرابيشي، بيروت، منشورات

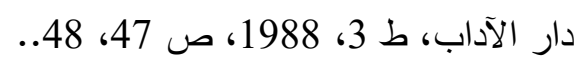

62-إريك فروم, الخوف من الحرية, ترجمة: مجاهد عبد المنعم مجاهد, بيروت, المؤسسة

العربية للدراسات والنشر , 1972, ص صوم 94.

63- إريك فروم, فن الحب بحث في طبيعة الحب وأشكاله, ترجمة: مجاهد عبد المنعم

مجاهد, بيروت, دار العودة, 2000, ص 78 78, 79.

64- آلان تورين، براديغما جديدة لفهج عالم اليوم، ترجمة: جورج سليمان، مراجعة سميرة

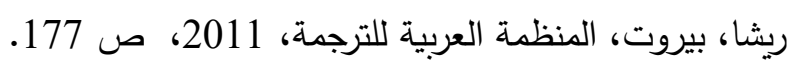


مجلة وادي النيل للاراسات والبحوث الإنسانية والاجتماعية ـ مجلة علمية محكمة

(ISSN : 2536 - 9555)

65- نعوم تشومسكي، الدول المارقة (استخدام القوة في الثئون العالمية)، ترجمة: أسامة إسبر، الرياض، مكتبة العبيكان، 2004، ص صل 444.

66- نعوم تشومسكي، النظام العالمي القديم والجديد، ترجمة:عاطف معتمد عبد الحميد، إثراف عام: داليا محمد إبراهيم، القاهرة، نهضة مصر، 2007، ص ص 272.

67-Murray Bookcin,The Ecology Of Freedom, P.263

68-Murray Bookchin, Cities: The Unfolding Of Reason In History,1995, In The Next Revolution :Popular Assemblies And The Promise Of Direct Democracy, Introduction By Debbie Bookchin And Blair Taylor,Verso Books, London ,2015,P.88,89.

69-Ibid,P.92,93.

70-Murray Bookchin,Urbanization Without Cities,P. Xiv.

71-Ibid,P.59/60.

72-Ibid,P.66,67.

73-Ibid,P.67,68.

74-Ibid,P.68-73.

75-Ibid,P.73\74.

76-Ibid,P.75-77.

77-Ibid,P.77,78.

78-Ibid,P.79,80,82.

79-Ibid,P.83.

80-Ibid,P.6,7.

81-Ibid,P. Xxiv.

82-Ibid,P. Xxv/Xxvi.

83-Ibid,P.10,11.

84-Ibid,P.54,55.

85-Murray Bookchin, The Next Revolution :Popular Assemblies And The Promise Of Direct Democracy, Introduction By Debbie Bookchin And Blair Taylor,P.11.

86-Murray Bookchin, The Ecological Crisis And The Need To Remake Society,1992 In The Next Revolution :Popular Assemblies And The Promise Of Direct Democracy, Introduction By Debbie Bookchin And Blair Taylor, Verso Books,London ,2015,P.44,45. 
نحو مجتمع بيئي إنساني: دراسة فى فلسفة موري بوكتثين

87-Murray Bookchin, A Politics For The Twenty - First Century,1998 In The Next Revolution :Popular Assemblies And The Promise Of Direct Democracy, Introduction By Debbie Bookchin And Blair Taylor, Verso Books,London,2015,P.48,49.

88-Ibid,P.61,62

89-Murray Bookchin, Libertarian Municipalism : Apolitics Of Dirict Democrscy,1991, In The Next Revolution :Popular Assemblies And The Promise Of Direct Democracy, Introduction By Debbie Bookchin And Blair Taylor,Verso Books,London,2015,P.78.

90-Ibid,P.80,81.

91-Murray Bookchin, Cities: The Unfolding Of Reason In History,P.87.

92-Murray Bookchin, Anarchism And Power In The Spanish Revolution,2002, In The Next Revolution :Popular Assemblies And The Promise Of Direct Democracy, Introduction By Debbie Bookchin And Blair Taylor, Verso Books,London,2015,P.118.

93-Murray Bookchin,Urbanization Without Cities,P. Xxiii., 94-Ibid,P. Xxiii/Xxiv.

95-Ibid,P.248-249

96-Ibid,P.250,251,254,255.

97-Ibid,P.258-259.

98-Ibid,P.259,260.

99-Ibid,P.271,272.

100-Ibid,P.282,283.

101-Murray Bookcin,The Ecology Of Freedom, P. 337,338.

102-Ibid,P.340.

103-جون لوك, الحكومة المدنية, ترجمة : محمود شوقى الكيال, القاهرة, مطابع شركة الإعلانات الشرقية, ص 83

104-جان جاك روسو, العقد الإجتماعى, ترجمة : عادل زعيتر , القاهرة, مؤسسة هنداوى للتعليم والثقافة, 2012, ص 51, 57 


$$
\begin{aligned}
& 105 \text {-ليوشتراوسوجوزيفكروبسى, تاريخ الفلسفة السياسية, الجزء الثانى من جونلوك إلى هيدجر , }
\end{aligned}
$$

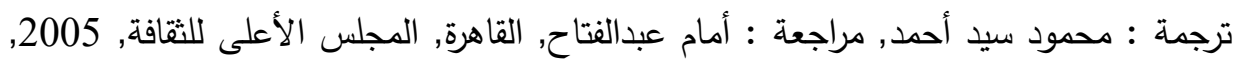

$$
\begin{aligned}
& 197 \\
& \text { 106-المرجع نفسه, ص } 326 \\
& \text { 107-المرجع نفسه, ص 304, 305, } 307 \\
& \text { 108-إريك فروم, الإنسان بين الجوهر والمظهر , ترجمة: سعد زهران, مراجعة وتقديم: لطفي }
\end{aligned}
$$

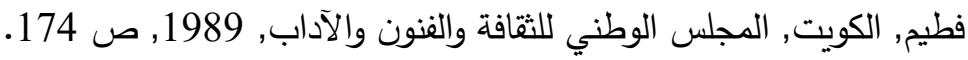

$$
\begin{aligned}
& \text { 109-روبرت دال, الديمقراطية ونقادها, ترجمة : نمير عباس مضفر, مراجعة : فاروق } \\
& \text { منصور , بيروت, دار الفارس للنشر والتوزيع, 2005, ص 135, 140, } 143
\end{aligned}
$$

110- John Rawls, Political liberalism, Columbia university press, New York, 1996., p. 216.

111 -Blain Everett Neufeld, Civic respect and Political plural subjects, The university of Michigan, 2002, p. 39.

112-آلان تورين, ما الديمقراطية, ترجمة: عبود كاسوحة, دمشق, منشورات وزارة الثقافة في

$$
\text { الجمهورية العربية السورية, 2000, ص 320- 321- 321- } 91 .
$$

113- Ronald Dworkin, Justice For Hedgehogs, London, Cambridge, Harvard university press, 2011, p. 365.

114- Ronald Dworkin, Is Democracy Possible Here?: Principles for A new political debate, Princeton, new jersey, Princeton university press, 2006, b131.

115- Ronald Dworkin, Sovereign Virtue, The Theory And Practice Of Equality, Harvard, Harvard university press, 2002, p. 358.

116-Murray Bookchin, The Communalist Project,P.28,29.

117-Murray Bookchin, The Ecological Crisis And The Need To Remake Society ,.P42,43.

118-Murray Bookchin, The Communalist ,P. 29.

119-Murray Bookchin, A Politics For The Twenty - First Century ,P. 58

120-Murray Bookchin, Libertarian Municipalism :Aplotics Of Dirict Democrscy ,P.82,83. 
نحو مجتمع بيئي إنساني: دراسة فى فلسفة موري بوكتثين

121-Ibid,P.84-85.

122-Murray Bookchin,Ecology And Revolutionary Thought,,P.31.

123-Murray Bookchin,Urbanization Without Cities,P.45-47.,

124-Ibid,P. 88.

125-Ibid,P.197,198.

126-Ibid,P.275,276. .

127-Michael Newman, Political Trials, 1993, P. 288.

$$
\text { 128-إدغار موران، هل نسير إلى الهاوية؟، ترجمة: عبد الرحيم حزل, ص80. }
$$

129-Ronald Dworkin, Liberal Community, California, Law Review, Vol. 77, No. 3, 1989, P. 501.

130-Murray Bookchin, The Ecological Crisis And The Need To Remake Society,P.41,42.

131-Murray Bookchin, A Politics For The Twenty - First Century ,P.51..

132-Murray Bookchin,Ecology And Revolutionary Thought,,P.31,32.

133- ستيفن ديلو وتيموثي ديل, التفكير السياسي والنظرية السياسية والمجتمع المدني, ترجمة

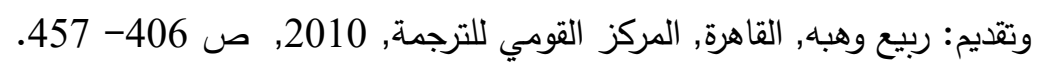

134- Ronald Dworkin, Liberal Community, P. 493- 494.

135-Murray Bookcin,The Ecology Of Freedom, P.346,347.

$$
\text { 136 1371-هربرت ماركيوز , نحو ثورة جديدة, ترجمة: عبد اللطيف شرارة, بيروت, دار العودة, }
$$$$
\text { فطيه, ص } 167 .
$$

139-Murray Bookcin, The Ecology Of Freedom, P.3.

140-Ibid,P.315-318.

141-Murray Bookchin,Ecology And Revolutionary Thought, p. 23. 
مجلة وادي النيل للاراسات والبحوث الإنسانية والاجتماعية ـ مجلة علمية محكمة

(ISSN : 2536 - 9555)

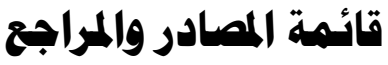

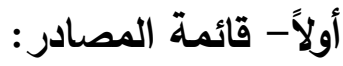

1-Murray Bookchin, Our Synthetic Environment, Knopf, The University Of Michigan,1962, Ecology

2-And Revolutionary Thought, Goddard College, 1965.

3-.................,The Ecology Of Freedom, Chshire Books, Usa, 1982.

4-....................,Urbanization Without Cities, Black Rose Book, 1992.

5-..........., Libertarian Municipalism : Apolitics Of Dirict Democracy, 1991, In The Next Revolution :Popular Assemblies And The Promise Of Direct Democracy, Introduction By Debbie Bookchin And Blair Taylor, Verso Books, London, 2015.

6-.............., The Ecological Crisis And The Need To Remake Society,1992 In The Next Revolution :Popular Assemblies And The Promise Of Direct Democracy, Introduction By Debbie Bookchin And Blair Taylor, Verso Books,London ,2015,.

7- ............, Cities: The Unfolding Of Reason In History, 1995, In The Next Revolution: Popular Assemblies And The Promise Of Direct Democracy, Introduction By Debbie Bookchin And Blair Taylor, Verso Books, London, 2015.

8-..............., A Politics For The Twenty - First Century,1998 In The Next Revolution :Popular Assemblies And The Promise Of Direct Democracy, Introduction By Debbie Bookchin And Blair Taylor, Verso Books, London, 2015. 
9-..............., Anarchism And Power In The Spanish Revolution,2002, In The Next Revolution: Popular Assemblies And The Promise Of Direct Democracy, Introduction By Debbie Bookchin And Blair Taylor, Verso Books, London, 2015.

10-................. The Communalist Project, 2002, In The Next Revolution :Popular Assemblies And The Promise Of Direct Democracy, Introduction By Debbie Bookchin And Blair Taylor,Verso Books, London, 2015.

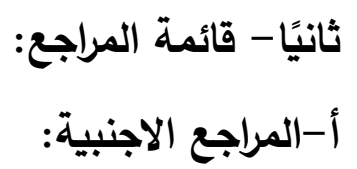

1-Blain Everett Neufeld, Civic Respect and Political Plural Subjects, the University Of Michigan, 2002.

2-John Rawls, Political Liberalism, Columbia University Press, New York, 1996.

3-Michael Newman, Political Trials, 1993.

4-Ronald Dworkin, Liberal Community, California, Law Review, Vol. 77, No. 3, 1989.

5-............,Sovereign Virtue, the Theory and Practice of Equality, Harvard, Harvard University Press, 2002.

$7-\ldots . . . \ldots \ldots \ldots . . . . ., \quad$ Is Democracy Possible Here? Principles For A New Political Debate, Princeton, New Jersey, Princeton University Press, 2006.

8-..................., Justice for Hedgehogs, London,

Cambridge, Harvard University Press, 2011. 


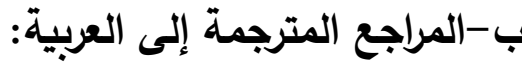

1. إدغار موران، هل نسير إلى الهاوية؟، ترجمة: عبد الرحيم حزل، الدار

$$
\text { البيضاء(المغرب)، أفريقيا الثرق، }
$$

2. إريك فروم, الخوف من الحرية, ترجمة: مجاهد عبد المنعم مجاهد,

$$
\text { بيروت, المؤسسة العربية للدراسات والنشر , } 1972 .
$$

3. . .................... الإنسان بين الجوهر والمظهر , ترجمة: سعد زهران, مراجعة

وتقديم: لطفي فطيم, الكويت, المجلس الوطني للثقافة والفنون والآداب, 1989. 4. . ................. فن الحب بحث في طبيعة الحب وأثكاله, ترجمة: مجاهد عبد المنعم مجاهد, بيروت, دار العودة, 2000.

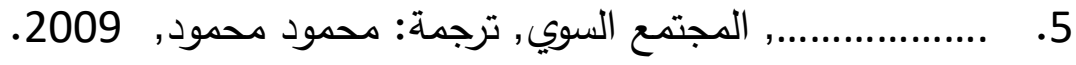
6. برتراند راسل, السلطة والفرد, ترجمة: شاهر الحمود, بيروت, دار الطليعة ترجة للطباعة والنشر , 1961. 7. آلان تورين، نقد الحداثة، ترجمة: أنور مغيث، القاهرة، المجلس الأعلى

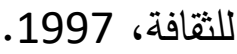

8. . ................... ما الديمقراطية, ترجمة: عبود كاسوحة, دمشق, منشورات وزارة الثقافة في الجمهورية العربية السورية, 2000.

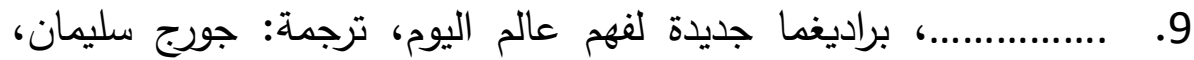
مراجعة سميرة ريشا، بيروت، المنظمة العربية للترجمة، 2011. 10. جالك أيلول, خدعة التكنولوجيا, ترجمة: فاطمة نصر , القاهرة, دار سطور , ليروال 
11. جان جالك روسو, العقد الإجتماعى, ترجمة : عادل زعيتر, القاهرة, مؤسسة هنداوى للتعليم والثقافة, 2012.

12. جون لوك, الحكومة المدنية, ترجمة : محمود شوقى الكيال, القاهرة, مطابع شركة الإعلانات الثرقية.

13. حنة آرندت، في العنف، ترجمة: إبراهيم العريس، بيروت، دار الساقي،

14. روبرت دال, الديمقراطية ونقادها, ترجمة : نمير عباس مضفر , مراجعة : فاروق منصور , بيروت, دار الفارس للنشر والتوزيع, 2005.

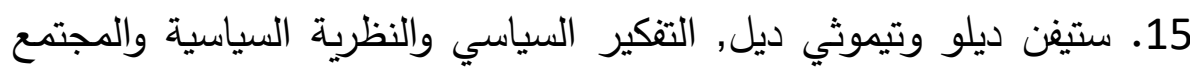
المدني, ترجمة وتتديم: ربيع وهبه, القاهرة, المركز القومي للترجمة, 2010.

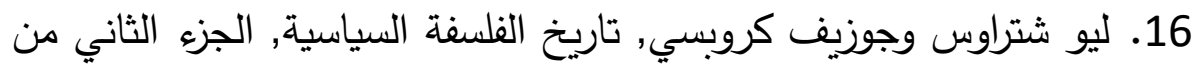

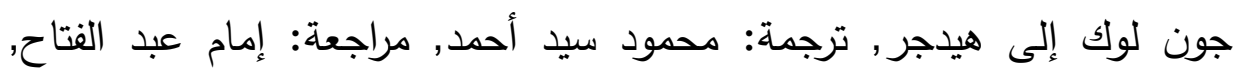
القاهرة, المجلس الأعلى للثقافة, 2005. 17. ماكس هوركهايمر , ثيودور • ف. أدورنو, جدل التنوير شذرات فلسفية,

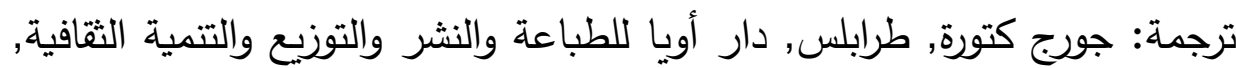
.2006 18. ميشيل فوكو، إرادة المعرفة، ترجمة مطاع صفدي و جورج صالح, بيروت, مركز الإنماء القومي, 1990. 19. نعوم تشومسكي، الدول المارقة (استخدام القوة في الثئون العالمية)، ترجمة: أسامة إسبر، الرياض، مكتبة العبيكان، 2004. 
مجلة وادي النيل للاراسات والبحوث الإنسانية والاجتماعية ـ مجلة علمية محكمة

(ISSN : 2536 - 9555)

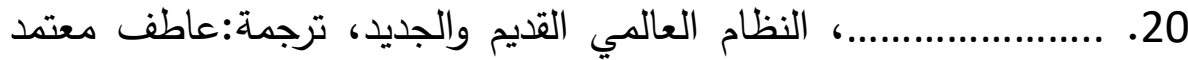

عبد الحميد، إشراف عام: داليا محمد إبراهيم، القاهرة، نهضة مصر، 2007.

21. هربرت ماركيوز , نحو ثورة جديدة, ترجمة: عبد اللطيف شرارة, بيروت,

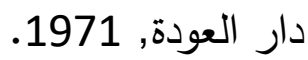

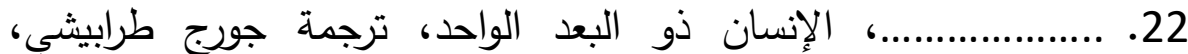

بيروت، منشورات دار الآداب، ط 3، 1988.

الحب والحضارة, ترجمة: مطاع صفدي, بيروت, دار

.23

الآداب للنشر والتوزيع, ط2, 2007. 